NBER WORKING PAPER SERIES

\title{
WHY DO DEFAULTS AFFECT BEHAVIOR? EXPERIMENTAL EVIDENCE FROM AFGHANISTAN
}

\author{
Joshua Blumenstock \\ Michael Callen \\ Tarek Ghani \\ Working Paper 23590 \\ http://www.nber.org/papers/w23590 \\ NATIONAL BUREAU OF ECONOMIC RESEARCH \\ 1050 Massachusetts Avenue \\ Cambridge MA 02139 \\ July 2017, Revised April 2018
}

We are grateful to Karim Khoja and the Roshan team for partnership in the design and implementation of the M-Pasandaz mobile savings product. We thank Hugo Gerard, Mohammad Isaqzadeh, Shahim Kabuli, Nasir Mahmoodi, Galen Murray, Ofir Reich, Sami Safiullah and Maria Qazi for excellent research assistance and Katy Doyle for outstanding project management. James Andreoni, Eli Berman, Marianne Bertrand, Prashant Bharadwaj, Leonardo Bursztyn, Stefano DellaVigna, Dean Karlan, Elizabeth Lyons, Craig McIntosh, Brigitte Madrian, Sendhil Mullainathan, Paul Niehaus, Matthew Olckers, Rohini Pande, Gerard Padró-i-Miquel, Gautam Rao, Stephen Ryan, Frank Schilbach, Jacob Shapiro, Charles Sprenger, Christopher Woodruff and many other colleagues provided insightful feedback. We thank seminar audiences at Berkeley, Georgetown, Harvard, Stanford, the University of Washington, the University of Zurich, and the World Bank. We acknowledge funding from the Citi/IPA Financial Capability Research Fund (FCRF), the Consortium on Financial Systems and Poverty (CFSP), the Empirical Studies of Conflict Project (ESOC), the Institute for Money, Technology, and Financial Inclusion (IMTFI), the UC San Diego Policy Design and Evaluation Lab (PDEL), and the USAID Development Impact Lab (USAID Agreement AID-OAA-A-13-00002). This work is also based on prior work supported by the U.S. Department of Defense Minerva research initiative through the Air Force Office of Scientific Research under award FA9550-09-1-000001. This RCT was registered in the American Economic Association Registry for randomized control trials under trial number AEARCTR-0000280. The views expressed herein are those of the authors and do not necessarily reflect the views of the National Bureau of Economic Research.

NBER working papers are circulated for discussion and comment purposes. They have not been peer-reviewed or been subject to the review by the NBER Board of Directors that accompanies official NBER publications.

(C) 2017 by Joshua Blumenstock, Michael Callen, and Tarek Ghani. All rights reserved. Short sections of text, not to exceed two paragraphs, may be quoted without explicit permission provided that full credit, including (C) notice, is given to the source. 
Why Do Defaults Affect Behavior? Experimental Evidence from Afghanistan

Joshua Blumenstock, Michael Callen, and Tarek Ghani

NBER Working Paper No. 23590

July 2017, Revised April 2018

JEL No. D14,D15,D9,O1

\section{ABSTRACT}

We report on an experiment examining why default options impact behavior. By randomly assigning employees to different varieties of a salary-linked savings account, we find that default enrollment increases participation by 40 percentage points-an effect equivalent to providing a $50 \%$ matching incentive. We then use a series of experimental interventions to differentiate between explanations for the default effect, which we conclude is driven largely by presentbiased preferences and the cognitive cost of thinking through different savings scenarios. Default assignment also changes employees' attitudes toward saving, and makes them more likely to actively decide to save after the study concludes.

Joshua Blumenstock

School of Information

102 South Hall

University of California, Berkeley

jblumenstock@berkeley.edu

Michael Callen

Rady School of Management

University of California, San Diego

Wells Fargo Hall, Room 4W104

9500 Gilman Drive \#0553

La Jolla, CA 92093-0553

and NBER

mjcallen@ucsd.edu
Tarek Ghani

Olin School of Business

Washington University in St Louis

1 Brookings Dr

St. Louis, MO 63130

tghani@wustl.edu

A randomized controlled trials registry entry is available at

https://www.socialscienceregistry.org/trials/280 


\section{Introduction}

Default assignments impact behavior. This observation is among the most influential and policy relevant insights from behavioral economics (Madrian, 2014). From organ donation (Johnson and Goldstein, 2003; Abadie and Gay, 2006) and vaccine use (Chapman et al., 2010) to exercise (DellaVigna and Malmendier, 2006) and marketing (Johnson et al., 2002), and especially in the domain of retirement savings decisions (Madrian and Shea, 2001; Choi et al., 2004; Beshears et al., 2009; Carroll et al., 2009; Chetty et al., 2014; Samuelson and Zeckhauser, 1988), individuals tend to remain at their default assignment. Yet, particularly as relates to retirement savings, economists still have an incomplete understanding of why defaults work.

This paper reports results from a field experiment in Afghanistan designed to identify the reasons why defaults affect behavior. We have several reasons for studying defaults in Afghanistan. First, most of the existing evidence on default savings is from rich countries. ${ }^{1}$ Less is known about the potential for defaults to affect savings in poor countries, where most of the world's population resides and where the economic benefits of increasing savings may be higher. Related, in developed countries, it is frequently the poorest and least financially sophisticated who respond most strongly to defaults (Madrian and Shea, 2001; Choi et al., 2004; Beshears et al., 2010a); this suggests defaults might be particularly effective in poor countries. Finally, while the lack of financial infrastructure has historically limited the relevance of default savings products in poor countries, the recent proliferation of mobile money, which already has more than half a billion registered accounts worldwide, promises to provide billions of "unbanked" individuals with a financial infrastructure that could support the use of defaults (GSMA, 2017).

We therefore worked with Afghanistan's largest mobile phone operator to design and experimentally evaluate a new phone-based default savings account, called "M-Pasandaz." 2 The study took part in two phases. In the first, each of 949 employees was randomly assigned to have either $0 \%$ or $5 \%$ of his or her salary automatically directed into a savings account. Separately, each employee was randomly assigned a financial incentive to save, with one third of employees receiving a $50 \%$ match on all contributions; one third receiving a $25 \%$ match; and the final third receiving no match. This phase makes it possible to compare the effect of 'nudging' employees with defaults and of incentivizing them with matches, and to experimentally estimate how defaults affect employee decisions and savings. In the second

\footnotetext{
${ }^{1}$ Reviewing the literature, we count six studies on automatic enrollment in savings programs in the U.S., along with one in Denmark, one in Australia, and one in Chile. Empirical evidence of default effects on other behaviors is similarly concentrated in rich countries (see a summary of studies in Appendix Table A1).

2 "Pasandaz" means savings in Dari, the most common language spoken in Afghanistan.
} 
phase of the study, we implemented a series of interventions designed to unstick employees from their default assignment and experimentally test several prominent explanations for default effects.

The first phase of the study produces three basic results. First, default assignments have large and significant impacts on employee participation and savings, of comparable magnitude to what is reported in the literature on defaults in developed countries (Appendix Table A1). Two months after the launch of the product and after almost all switching of contribution rates had ceased, employees randomly assigned a default contribution rate of 5 percent were 40 percentage points more likely to contribute to the account than individuals assigned a default contribution rate of zero. We collected several rounds of follow-up surveys with each employee, and while the data are too imprecise to draw firm conclusions, we find no evidence that M-Pasandaz crowded out other savings.

Second, we "price" the default relative to matching contributions, and estimate the elasticity of participation with respect to the match rate. While prior research examines the effect of matching incentives on savings (Duflo et al., 2006; Engelhardt and Kumar, 2007), and more recent work indicates that savings programs incorporating default contributions are more likely to increase participation than monetary incentives alone (Chetty et al., 2014; Madrian, 2013), to our knowledge this is the first study to experimentally compare default and incentive effects on the same population for a single product. We find that default assignment increases participation by roughly the same amount as a $50 \%$ match on employee contributions. We further find that the elasticity of participation with respect to the match rate is about one, independent of default status.

Third, we find that defaults affect employee attitudes and interest in saving, even long after the experiment concludes. Most notably, we removed all financial incentives to contribute at the end of a six-month trial, and asked each employee to make an active decision about whether to continue contributing. Even absent incentives, $45 \%$ of employees elected to contribute, with participation $25 \%$ higher in the group that was randomly assigned a positive default contribution rate at the beginning of the trial. Employees defaulted into savings reported significantly higher levels of financial security, and two years later, their savings balances remained larger than those randomly defaulted out of savings during the trial. Such evidence is consistent with the idea that employees might form habits through the experience of saving (Becker and Murphy, 1988; Charness and Gneezy, 2009), perhaps through better financial planning (Thaler, 1999; Schaner, 2016). More broadly, these results can inform the larger discussion of whether using defaults to change financial behavior is welfare improving by suggesting that automatic enrollment can cause employees to learn about the costs and benefits of saving (Bernheim et al., 2015). 
The rest of the paper explores why default assignments impact savings. Here, we attempt to differentiate between five explanations offered by the literature; the first three are consistent with rational models, and the latter two with behavioral models. First, defaults may persist because of an employer 'endorsement' effect whereby decision-makers, unsure of the best course of action, take the default as reflecting a recommendation by a benevolent planner (Madrian and Shea, 2001; Choi et al., 2004; Madrian, 2014). Second, there may be significant real or perceived costs involved in switching from the default election, due to mechanical frictions in changing one's contribution rate. Third, and closely related, there may be a large mental cost associated with the complexity of forming a financial plan (Lusardi and Mitchell, 2011; Cole et al., 2011; Drexler et al., 2014). Fourth, turning to behavioral theories, employees may be unaware of their election, or the possibility of switching may not be salient in their minds (Karlan et al., 2016b; Taubinsky, 2013; Kast et al., 2016). Finally, because changing defaults involves some immediate costs with delayed benefits, individuals may not switch, particularly if they are present-biased and naive about their future preferences (O’Donoghue and Rabin, 1999).

Our data do not support the first two explanations for why defaults affect behavior. First, our research design eliminates employer 'endorsement' effects by construction: the open lottery used to assign default status and matching incentives makes clear to employees that assignments do not reflect the deliberation of a benevolent planner, and this understanding is clearly visible in follow-up surveys with employees. ${ }^{3}$ We also see little evidence that the "default in" assigned rate of $5 \%$ was perceived as optimal - only 6 of 472 employees (1.3\%) actively chose to contribute at $5 \%$ (most people who opted in did so at the maximum of 10\%). Second, every effort was made to minimize the mechanical cost of switching. For instance, to change their contribution rate, employees simply needed to let someone from their human resources department know - this could be done in person, via a phone call, or by sending an email or text message. Our survey data indicate that employees were clearly aware of their contribution level and knew how to change it if they wanted to. ${ }^{4}$

Similarly, we find that large default effects persist after deploying a series of interventions designed to increase the salience of default assignment. These include randomly assigned text messages as well as randomly assigned financial surveys, neither of which resulted in significant switching. The strongest evidence we can find of inattention occurred three weeks into the study on the first payday, when 22 of our 943 participants (2.33\%) switched their

\footnotetext{
${ }^{3}$ In the endline survey, for instance, $75 \%$ of the 816 respondents confirmed their belief that the assignment of matching incentives was random, while $14 \%$ indicated they did not think it was truly random, and $11 \%$ indicated that they were unsure.

${ }^{4}$ For instance, $87 \%$ of employees report fully understanding how the product works, and $96 \%$ of participants were aware of their match rate.
} 
contribution, which was a modest increase over the number of switches on previous days. Thus, while limited attention clearly affects savings decisions in other contexts and plays a small role here, it is unlikely to explain the default effects observed in our context.

By contrast, there is much in our data to suggest that default effects in savings persist because employees face significant cognitive costs associated with identifying their optimal contribution rate, and that this cost, together with present-biased preferences, creates procrastination. We elicited several measures of present bias-including hypothetical and incentivized behavioral elicitations, as well as through a real-world task over which employees could procrastinate - and find that present-biased employees were significantly more likely to remain at their default assignment (even controlling for their long run discount factor and a broad set of observables). Further, of the experimental interventions we implemented - all of which were designed to encourage employees to choose a non-default contribution rate - the only one that proved effective was to offer employees a thorough financial consultation designed to reduce the cognitive cost of designing a financial plan. This consultation consisted of several modules, and the component that stands out as most associated with switching is one that helped employees calculate how much money they would save under different contribution scenarios.

To summarize, this paper makes several contributions relative to existing research on the impact of default assignment on savings behaviors. First, we provide the first experimental evaluation of a default payroll contribution account, and show that experimental estimates of the default effect in a developing country are comparable to estimates from the U.S. and western Europe. Afghanistan differs profoundly from most of the countries where defaults have been researched. Forty years of civil war have left the country as one of the world's poorest and most unstable. ${ }^{5}$ Distrust of financial institutions is high, and only $4 \%$ of the population saves with a bank (Demirguc-Kunt et al., 2015). There are no income tax considerations related to our product and no asset mixes to choose between. The similarity of our results to those in developed countries provide additional evidence that default savings effects are a very general phenomena. ${ }^{6}$

Second, our controlled environment makes it possible to investigate outstanding questions about default effects, including the 'price' of the default relative to financial incentives and

\footnotetext{
${ }^{5}$ According to the 2016 World Development Indicators, Afghanistan has a per capita GDP (PPP-adjusted) of $\$ 1,877$, ranking 156 out of 175 countries. According to Transparency International's 2016 Corruption Perceptions Index, Afghanistan ranks 169 out of 176.

${ }^{6}$ However, two important caveats are in order. First, we experimentally evaluate a six month commitment product and not a retirement fund. Second, our sample is not representative of the larger Afghan population: these employees are all salaried and tend to be wealthier (nominal GDP per capita in Afghanistan is around $\$ 600$ USD while the median annual salary in our firm is $\$ 5,415.60$ USD). However, even amongst the poorer employees in our sample, who are more comparable to the broader population, we find clear default effects.
} 
the impact of defaults on savings attitudes future savings decisions. Our design also allows exploration of the mechanisms underlying the default, which together highlight the cognitive cost of deciding how much to save and the role of present-bias in the persistence of default effects. Here, our paper relates most closely to several recent studies showing that whether someone remains in a default assignment is predicted by measures of procrastination (Brown and Previtero, 2014; Brown et al., 2016; Goda et al., 2015). Relative to these efforts, our study benefits from experimental variation in default assignment, as well as a series of crossrandomized interventions designed to compare present bias to other common explanations for default effects.

A key feature of M-Pasandaz is that default salary contributions are passive. Once enrolled, contributions are automatic and do not require any action from the saver (Chetty et al., 2014). This may be particularly important in developing countries where many of the primary obstacles to saving, from simple transactions costs associated with traveling to the bank (Burgess and Pande, 2005; Callen et al., 2017), to intra-household disagreements regarding savings (Anderson and Baland, 2002; Ashraf, 2009; Schaner, 2015), behavioral issues of dynamic inconsistency (Ashraf et al., 2006; Karlan et al., 2016b; Dupas and Robinson, 2013), temptation good (including drug and alcohol) consumption (Banerjee and Mullainathan, 2010; Schilbach, 2017), and ego depletion (Shah et al., 2012), all relate to the fact that savings must first pass through the saver's hands, who must then make an active decision to save (Karlan et al., 2014; Madrian, 2013).

We are optimistic that these insights can create new options for improving the savings prospects of many people historically left out of formal financial ecosystems. For while very few Afghans save with a bank, $90 \%$ have access to a mobile phone, and a growing share use mobile money. This is emblematic of a global pattern: only $22 \%$ of adults in developing countries report saving in formal accounts (Demirguc-Kunt et al., 2015), and in sub-Saharan Africa, the number of mobile money accounts has already surpassed bank accounts (GSMA, 2017). In concert, the International Labor Organization estimates that the share of the developing world's households in the middle class or above more than doubled from 1991 to 2011, and was projected to pass $50 \%$ in 2017, with over $60 \%$ of these workers in wage employment (Kapsos and Bourmpoula, 2013). ${ }^{7}$ As the share of wage earners in developing countries increases, and as electronic payment systems become more common, products like M-Pasandaz can provide new options for mobilizing savings.

The rest of the paper proceeds as follows. Section 2 provides background on the Afghan

\footnotetext{
${ }^{7}$ Demirguc-Kunt et al. (2015) report that 400 million unbanked adults receive wages or government transfers in cash. The payment of salaries via mobile money is now happening in South Asia, Sub-Saharan Africa and Latin America (cf. Karlan et al., 2016a; Aker et al., 2016; Breza et al., 2017); phone-based and electronic welfare payments are also becoming increasingly common (Muralidharan et al., 2016).
} 
context. Section 3 describes the M-Pasandaz product and the experimental design to evaluate its effect on savings. Section 4 reports the impact of default enrollment and Section 5 discusses the potential role of present-biased preferences in creating a default effect and considers alternative explanations. Section 6 concludes.

\section{Financial Inclusion in Afghanistan}

After four decades of political instability and conflict, Afghanistan remains one of the poorest countries in the world. The formal financial sector is small, with only 2.3 banks per 100,000 adults, and only $4 \%$ of adults reporting any formal savings over the past year (International Monetary Fund, 2015; Demirguc-Kunt et al., 2015). ${ }^{8}$ Yet a demand for savings exists, as roughly $25 \%$ of Afghans report saving in the previous year, primarily through cash or in-kind holdings (Demirguc-Kunt et al., 2015; Chipchase et al., 2013). Among our study population, many respondents report keeping U.S. dollars rather than Afghanis, the local currency, and when making long-distance transfers forego wire services in favor of hawalas, a trust-based network of money brokers. While saving money to buy a house or a car seems out of reach for most, saving money in case of death or illness is essential. They often store their money in a metal box at home (a traditional method), or with a trustworthy (often wealthier) relative. They tell stories of themselves or people they know going hungry or reducing food quality after a shock of some kind, and describe the shame of young men unable to marry for lack of money.

While bank presence is limited, mobile phones are prevalent throughout the country, with approximately 75 mobile cellular subscriptions for every 100 Afghan adults (International Telecommunication Union, 2015). More recently, several operators in Afghanistan launched "mobile money" platforms, which deliver rudimentary financial services to subscribers over the mobile phone network. We focus on one such mobile money platform, "M-Paisa," which was launched in 2008 by Roshan Telecom, and which, at the time of our study, was the nation's largest mobile money network with 1.2 million unique subscribers. In Afghanistan, as in other countries, mobile money uses SMS-like functionality to enable the exchange and storage of value over a basic mobile phone interface, complemented by a real-world network of agents providing "cash-in" deposit and "cash-out" withdrawal services. As mobile phone penetration rates surge in developing countries, mobile money has emerged as a possible financial instrument for the poor, and there are now more than 500 million registered ac-

\footnotetext{
${ }^{8}$ Afghan banks offer short-term savings accounts with a floating interest rate and long-term "fixed deposit" accounts with a fixed interest and term, though the reported rates often fall below the annual inflation rate, which ranges between $5 \%$ and $10 \%$.
} 
counts using 277 mobile money services in 92 countries, with 118 million accounts active in December of 2016 (GSMA, 2017). These accounts have historically been used primarily for interpersonal transfers (Jack and Suri, 2014; Blumenstock et al., 2016), and in Kenya, the country where mobile money is most widespread, have led to considerable reductions in poverty (Suri and Jack, 2016). More recently, however, many mobile operators have begun to offer more sophisticated financial services, including interest-bearing savings accounts, insurance, and credit products. ${ }^{9}$

\section{3 "Mobile-izing" Savings with M-Pasandaz}

We worked with Roshan, Afghanistan's largest mobile network operator, to develop a new product for the M-Paisa mobile money system, called "M-Pasandaz." M-Pasandaz facilitates automatic payroll deductions and employer matching contributions using mobile money. ${ }^{10}$ Specifically, a Roshan subscriber who owns a mobile money (M-Paisa) account and is paid via mobile money can enable a parallel mobile M-Pasandaz wallet and select to have a portion of her salary automatically deducted into this wallet during each pay cycle. Consistent with Islamic principles, these contributions do not earn interest, but employers may provide matching incentives. ${ }^{11}$

Through our study, we provided different versions of the M-Pasandaz account to all eligible Roshan employees. Our study population consists of 949 full-time Afghan national employees of Roshan, about $15 \%$ of whom are women (Appendix Table A2). ${ }^{12}$ Employees hold job titles such as Manager, Engineer, Security Guard and Janitor and are located in six major regional offices: Kabul, Kandahar, Mazar, Herat, Ghazni and Kunduz. Prior to the launch of M-Pasandaz, all of these employees were being paid with M-Paisa direct deposits;

\footnotetext{
${ }^{9}$ See Aker and Blumenstock (2014) for a review of recent literature, and GSMA (2017) for a comprehensive report on mobile money in developing countries.

${ }^{10}$ Prior to our collaboration, Roshan had for a number of years aspired to create a defined contribution program for their employees. Automatic payroll deductions are widely used to promote savings in developed countries (Beshears et al., 2009). There are also examples of automatic payroll deductions for savings in developing countries, such as publicly-mandated pension (or "provident") funds for private sector workers in India, Malaysia and elsewhere. While Afghanistan does not currently mandate pension plans for private sector employers, several of the larger employers, including telecoms and international NGOs, voluntarily offer such programs. During the study, several private pension and savings schemes were active in Afghanistan, permitting employee contribution rates between 5-10\% of monthly salaries with employer matches of up to $100 \%$ of deposits and vesting periods ranging from monthly to annual.

${ }^{11} 24$ employees (2.5\%) described the product as un-Islamic when explaining why they did not to participate.

${ }^{12}$ At the time of our baseline survey in June 2014, Roshan had roughly 1,100 employees, of whom roughly $90 \%$ were Afghan national staff paid using mobile money. We exclude from our sample a group of 18 employees who participated in qualitative focus groups and pilot product development, as well as those employees who had left Roshan prior to the launch of M-Pasandaz in January 2015, leaving us with an experimental sample of 949 employees.
} 
that is, each month their monthly wages are deposited into their normal M-Paisa mobile money account. ${ }^{13}$ The average tenure in our sample was 5.8 years, and all of Roshan's Afghan employees had received mobile salary payments since 2010, so this population was familiar with the mobile money system.

Several aspects of the M-Pasandaz account werse held constant across all employees. Most relevant to our design, deposits into M-Pasandaz could only be made via direct deposit at the time of the regular monthly salary payment; there was no other way to transfer funds into the M-Pasandaz account. Each pay cycle, regardless of the amount contributed by the employee to M-Pasandaz, the employee would receive an SMS confirmation indicating how much had been paid via direct deposit and how much had been placed in the employee's M-Pasandaz account. Employees were free to check the balance on their accounts and to electronically withdraw money at any time; this was done to enable access to liquidity in times of urgent need. However, any withdrawal made during the initial six-month commitment period would forfeit that employee's eligibility for matching incentive payments and eliminate the accrued matches from their employer. ${ }^{14}$ All employees were required to attend a 60 -minute training session, during which a representative from Roshan Human Resources described M-Pasandaz as a "new benefit offered by Roshan" and explained the details of the account.

Two key features of M-Pasandaz account were randomized between employees. First, employees were randomly assigned a default contribution rate. For half of employees, the default contribution was set to $5 \%$ of their monthly salary; for the other half, the default contribution was set to $0 \%$. To simplify the later exposition, we will occassionally refer to the $5 \%$ group as the "default in" group, and the $0 \%$ group as the "default out" group. Note, however, that all employees were given an account and enrolled, the difference between groups was simply their default-assigned contribution rate, which all employees had the option to change at any time.

Subjects were also randomly assigned to one of three different levels of matching incentive for M-Pasandaz contributions, creating a 2 x 3 design. The employer characterized these as three different M-Pasandaz "plans" that are distinguished only by the level of matching incentives: White (0\% match), Blue (25\% match) and Red (50\% match). ${ }^{15}$ Thus, for each

\footnotetext{
${ }^{13}$ While there is a withdrawal fee for "cashing out" of the mobile money system, each mobile salary payment includes the cost of one withdrawal to ensure the entire salary was transfered. See Blumenstock et al. (2015) for a more detailed discussion of the extant mobile salary payment technology in Afghanistan.

${ }^{14}$ The M-Pasandaz account was similar to a commitment savings account in that withdrawals prior to the six-month deadline forfeited a potential incentive payment, but had key differences in that default enrollment was linked to salary payments and participants could recover their own contributions at any time without penalty.

${ }^{15}$ These incentive levels are similar to those in prior literature from developed country (Duflo et al., 2006) and developing country settings (Carter et al., 2015), and were consistent with savings incentives provided by Roshan's competitors in Afghanistan.
} 
monthly deposit to M-Pasandaz made by the employee, the employer would make a corresponding deposit at the level specified by the employee's plan. Employees were informed that these matching incentives would be available at the end of the six-month commitment period, but that all accrued incentives would be lost if a withdrawal was made before then. As opposed to the contribution rate, which the employee could change easily, the employee could not change his or her matching incentive. Finally, Roshan paid taxes in advance on the matching incentives, so employees received the exact amount specified by their plan.

Employees were informed of both their matching incentive and their default contribution rate at the end of the HR training session through a personalized card that was distributed by the HR representative. During training, employees were informed that they could change their contribution rate at any time by calling or visiting the HR department, and this contact number was included on the personalized card; the goal was to minimize the friction involved in switching contribution rates. Employees were free to set their contribution rate to any value between $0 \%$ and $10 \%$ of their monthly salary. Importantly, this created scope for the default in group to either increase or decrease their contribution, while the default out group could only increase their contribution. Any change in the contribution rate was instantaneous and applied to all future salary payments, with the caveat that each month's contribution was locked in on the 15 th of the month to give HR sufficient time to prepare monthly payments, which typically occurred on the 20th of the month.

Both treatments were stratified by employee salary terciles, self-reported perceptions of physical insecurity, and provincial office locations, using data collected in a face-to-face baseline survey of all employees in May and June 2014. We used a "big stick" approach to randomization to ensure that no key characteristics were imbalanced with a p-value of less than 0.1 (Bruhn and McKenzie, 2009). ${ }^{16}$ Appendix Table A2 reports balance tests on a range of observable characteristics across all six resulting combinations of the primary treatments.

In December 2014, employees attended the HR training session and were informed of their default contribution rate and plan assignments. An "open enrollment" period during which employees could change their contribution rate began on December 30, 2014 and lasted until January 15, 2015, and the first automatic contributions were made on January 21, 2015. The sixth and final automatic contribution occurred on June 21, 2015, and incentive payments were distributed on July 23, 2015. Over the study period, we conducted four phone-based follow-up survey waves with a randomly selected panel of half the employees. In August 2015 we conducted a final face-to-face endline survey with all employees participating in the

\footnotetext{
${ }^{16}$ In applying the 'big stick' we checked for balance on salary, total savings, and a dummy variables for: (i) regularly using a bank; (ii) being confident in paying monthly bills; (iii) expecting violence; (iv) not being satisfied with mobile salary payments; and (v) withdrawing the entire paycheck on payday.
} 
study.

\section{The Default Effect}

\subsection{The Default Effect on Participation and Contributions}

During the six-month study window, 459 of the 949 employees (48.3\%) elected to change their contribution rate from their default assignment; the remaining 490 employees remained at the default. As shown in Figure 1, most of the employees who switched did so in the first three weeks of the study. Employees who switched came from all plan types (Appendix Figure A1) and cited a variety of reasons for doing so (Appendix Table A3). While many employees did change their contribution rate, the effect of the default is evident in the large number of employees who never moved from their default (Figure 2). For instance, 39\% of employees who were assigned a default rate of $0 \%$ in the Red plan - all of whom would have received significant financial incentives to save - left "cash on the table" by continuing to contribute $0 \%$ of their salary to M-Pasandaz. Similarly, $36 \%$ of the employees in the White plan who were assigned a default rate of $5 \%$ continued to contribute $5 \%$ of their salary to M-Pasandaz, even though they received no financial incentives to do so. ${ }^{17}$

We estimate the causal effect of defaults in Table $1 .{ }^{18}$ Employees who are "defaulted in" at $5 \%$ are 40 percentage points more likely to contribute to the account than employees defaulted to $0 \%$ (Panel A, column 1). ${ }^{19}$ Similarly, random assignment to a $5 \%$ contribution increases 6-month contribution rates by 1.77 percentage points (Panel B, column 1), equivalent to a $66 \%$ increase over the control group's average contribution rate of $2.7 \% .^{20}$ Thus, the net effect of default enrollment was to increase monthly employee contributions by 2,426 Afghanis (\$40 USD, Panel C), roughly $10 \%$ of the median monthly wage.

The magnitude of the default effects we observe are remarkably consistent with previous non-experimental estimates of the default effect in developed countries (Appendix Table A1).

\footnotetext{
${ }^{17}$ These percentages reflect behavior after two months, and prior to the launch of several randomized follow-up interventions designed to nudge employees from their default assignment. Behavior over other relevant periods is presented in Table 4.

${ }^{18}$ Because we are interested in interpreting the constant terms in the regressions, Tables 1-4 do not include stratum fixed effects; the versions including stratum fixed effects are provided in Appendix Tables B1 - B4.

${ }^{19}$ In Appendix Table A4, when participation is defined as making a non-zero contribution and never making a withdrawal, defaulting enrollment increases participation by 31 percentage points. In Appendix Table A5, we find qualitatively similar effects for particiption and contribution rate using the values of these variables at the end of the study on July 15th instead of February 28th.

${ }^{20}$ Whereas the effect on participation is present for all levels of matching incentives (Panel B, columns 1-3), the effect on contribution rates is only present in the White (0\% matching contributions) and Blue $(25 \%$ matching contributions) plans (Panel B, columns 2-4), suggesting that the strongest financial incentives may have been sufficient to overcome the default effect.
} 
And while the employees we study are not representative of the broader Afghan population, they do exhibit considerable heterogeneity in income and other sociodemographic characteristics (Appendix Table A2). In our sample, we find that the magnitude of the default effect is remarkably consistent across salary quartiles (Appendix Table A6).

We were naturally interested in understanding whether the increase in M-Pasandaz savings represents a net increase in total savings, or whether employees are instead substituting out of other financial instruments, as has been the case in several studies in the U.S. and Western Europe. ${ }^{21}$ We thus conducted a series of longitudinal follow-up surveys to ask employees about their financial behaviors. Unfortunately, the limited size of our sample, along with the imprecision of the data captured in the recall survey, do not allow us to draw any firm conclusions about whether the increase in M-Pasandaz affected other types of savings. These effects are discussed in greater detail in Appendix Section A, and summarized in Appendix Table A7. In sum, we do not see evidence that the default contributions crowded out other types of saving, or reduced food expenditures (a potential concern for the poorer workers in our sample), but we also see no sign of increased net savings for the average employee.

\subsection{Comparing the Default Effect to Matching Incentives}

Employees also responded strongly to the matching incentives provided by the employer. As can be inferred from the constant terms in columns 2-4 of Table 1 (Panel A), among employees initially assigned a contribution rate of $0 \%$, the participation rate was $1 \%$ for employees with no matching contributions, $27 \%$ for employees with $25 \%$ matching contributions, and $57 \%$ for employees with $50 \%$ matching contributions.

Our design enables us to directly compare the default effect to the effect of matching incentives. Figure 3 relates the default effect to the effect of matching incentives, using the coefficients estimated in Table 1. At all levels of matching incentives, participation and contribution rates are higher for the group of employees with a $5 \%$ default than for those with a $0 \%$ default, and for both groups the elasticity of participation with respect to the employer match rate is approximately one.

These results can inform the broader debate regarding the effectiveness of behavioral nudges relative to traditional incentives (cf. Chetty et al., 2014). In our context, the employer would need to match employee contributions at $50 \%$ to achieve the same participation rate

\footnotetext{
${ }^{21}$ Prominent examples include Benjamin (2003), Chetty et al. (2013), and Beshears et al. (2017). We are not aware of prior work on automatic contribution programs in developing countries. The closest examples are Brune et al. (2017) and Somville and Vandewalle (2017), who study "default" effects by experimentally manipulating whether beneficiaries are paid in cash or to a bank account. In both studies, benficiaries paid via bank transfer save more than those paid in cash.
} 
as from merely having employees contribute by default. More concretely, we can calculate the implicit value of the nudge to the employer in forgone matching incentives: At the end of the six month pilot, the 159 employees in the $50 \%$ match plan who were defaulted out received a total payout of $699,323 \mathrm{AFA}(\$ 13,986.46 \mathrm{USD})$. If the employer instead only gave all employees a $50 \%$ match and defaulted them in at $0 \%$, Roshan would need to provide $\$ 83,479$ USD (or $\$ 87.97$ USD per employee) in incentives to achieve the same participation rate as from only defaulting employees in at $5 \%$ with a $0 \%$ matching incentive. $^{22}$

\subsection{Active Decision and Long-Run Effects}

Employees who were randomly induced to save more through our interventions also developed an interest in saving that persisted after the termination of the experiment. Most notably, at the conclusion of the 6-month study period, all financial incentives were removed, and employees were individually asked whether they would like to have a portion of their future salary automatically deposited into their M-Pasandaz account. We required each employee to make this decision actively, and the decision was the same for all employees independent of their treatment status during the main experiment. As shown in Table 2, the desire to continue contributing was significantly higher for the employees who were exogenously induced to contribute more through a positive default-assigned contribution rate, particularly in the $0 \%$ matching rate group. ${ }^{23}$ Overall, employees defaulted in to participating during the experiment were 10 percentage points (25\%) more likely to actively decide to continue to contribute a portion of their salary to M-Pasandaz. We find that matching incentives had similar effects.

Using Roshan's administrative data, which spans one and a half years after experiment, we can also examine how long default effects persist after matching incentives were removed. ${ }^{24}$ Figure 4 shows M-Pasandaz participation rates and balances, separately by default status, for the six months of our study as well as the following 18 months. As discussed above, savings increased substantially during the study period, and differentially for employees defaulted in. Participation dropped steeply once financial incentives were removed, but many employees

\footnotetext{
${ }^{22}$ To generate an equivalent average contribution, rather than an equivalent degree of participation, requires a $25 \%$ matching incentive. To see this, in Panel B of Table 1, defaults increase the average contribution in the $0 \%$ match group by 2.38 percentage points, which is roughly the average contribution of the group defaulted out with a $25 \%$ matching contribution.

${ }^{23}$ This, in itself, does not necessarily signal habit formation in the sense of Becker and Murphy (1988). Increased interest in the product may just be, for example, that employees have learned more about how much they can comfortably save each month. Hussam et al. (2017) provides a direct experimental test for rational addiction.

${ }^{24}$ Charness and Gneezy (2009), Schaner (2016), and Hussam et al. (2017) provide other examples of how short-run incentives can affect behavior even after incentives are removed.
} 
continued to contribute, particularly among those randomly assigned to a $5 \%$ default. These results are tabulated and disaggregated by matching incentive in Appendix Table A10.

\subsection{Why Did Enthusiasm for M-Pasandaz Increase?}

Why were employees initially defaulted in to savings more likely to later make an active decision to save, and to continue to contribute long after financial incentives were removed? Our survey data indicate that part of the explanation is that the experience of saving changed employee perceptions. Employees defaulted in to savings during the experiment were less likely to report feeling too financially constrained to save, more likely to feel that savings is important, and more likely to feel confident in meeting their financial obligations. These results are presented in Table 3, where column 1 indicates the average response among employees assigned a default contribution rate of $0 \%$, and column 2 indicates the increase in response for employees assigned a default contribution rate of $5 \%$. Since this table includes several outcomes that were not a part of our pre-analysis plan, we focus on three summary indices in Panel A (importance of saving, financial security, and general well-being), and report a set of p-values that asymptotically control the Family Wise Error Rate (the probability that any true null is rejected) at $0.05 .{ }^{25}$ Panels B-D report the individual survey questions from which the indices are constructed. Appendix Table A12 reports the effects of randomly assigned matching rates on financial perceptions.

The impact of the default on financial perceptions can be seen in the first two rows of Table 3, Panel A. Default enrollment increased a composite index of the perceived importance of saving by 0.14 standard deviations and a summary measure of perceived financial security by 0.11 standard deviations. Results for each of the survey outcomes that comprise the two composite indices are reported in Panels B and C. Most notably, defaulting employees in substantially raised the share of employees who believed that they were not too financially constrained to save. This might reflect the relaxation of a real constraint, where participation in M-Pasandaz moved employees beyond some minimum threshold of savings to begin to feel comfortable saving every month, or might reflect a realization that their prior perception that they were too constrained to save was inaccurate. ${ }^{26}$ This seems reasonable in the context of a six-month pilot that meaningfully affected short-run finances, but which ended before

\footnotetext{
${ }^{25}$ This practice follows a growing literature on addressing potential Type I error arising from multiple hypothesis testing in experiments (Casey et al., 2012; Bidwell et al., 2016). Romano (2010) provides a review. List et al. (2016) describe a technique that simultaneously controls for several sources of Type I error in field experiments. We control the Family Wise Error Rate for consumption and the three summary indices and then for all of the variables that comprise the indices separately.

${ }^{26}$ In Appendix Table A11, we find the results on the importance of savings are driven primarily by the $0 \%$ matching rate group, consistent with updating prior beliefs about their ability to save without incentives.
} 
more sustained impact could be realized. Modest but significant default effects are likewise observed in employees' attempts to save each month, and in their sense that the M-Pasandaz program itself changed their desire to save. In Panels D and E, we examine a broader set of measures of well-being. In general, we do not find evidence that the M-Pasandaz program impacted measures of food security, happiness, or employment outcomes.

Collectively, these data indicate that the M-Pasandaz program - and default assignment in particular - significantly increased enthusiasm for saving during the 6-month trial, in part by helping employees change their beliefs about how much they could feasibly save. More broadly, these results suggest that use of the product caused employees' savings behaviors to become more consistent with their own stated long-run preferences. Indeed, prior to the study, participants expressed a strong sense that savings was important to them, but that they simply did not have enough money to save. ${ }^{27}$ This is broadly consistent with evidence in more familiar contexts. For instance, Choi et al. (2004) find that many employees report wanting to save more, suggesting that defaults might help them overcome a behavioral issue that is impeding their savings goals. And to the extent that policy makers privilege welfare determined using ex ante preferences (Bernheim et al., 2015), these results suggest that the inducement to save was, on average, welfare improving. This is important in our setting, where $27 \%$ of participants reported that at least one family member went without a meal in the week prior to the baseline survey, and there is a concern that defaults may cause employees to 'over save.'

\section{$5 \quad$ Understanding the Default Effect}

The effect of automatic enrollment - approximately equivalent to a $50 \%$ employer match - is striking, and consistent with evidence on automatic payroll deductions in wealthier nations.Madrian (2013) and Beshears et al. (2009) review common explanations for this large default effect. First, and prominent in the U.S. literature, is the possibility of an 'endorsement' effect: employees may perceive their initial assignment as a recommendation from the employer, leading the employee to defer to the employer's wisdom and remain at the assigned rate. Second, there may be mechanical frictions involved in switching; when this cost exceeds the benefit from switching, employees will remain at their default. Third and related, employees may face large (real or perceived) cognitive costs of forming a financial plan. Fourth, employees may be aware of their contribution and know how to switch, but

\footnotetext{
${ }^{27}$ Only one of the 161 employees defaulted to a $0 \%$ contribution with no matching incentive opted in during the first two pay periods. Under the active decision, which effectively placed all employees in the White plan with no matching incentives, 45 percent of employees chose to contribute.
} 
the decision may not be salient to the employee, or the employee may be inattentive (Karlan et al., 2016b; Mullainathan and Shafir, 2013; Taubinsky, 2013; Mani et al., 2013). A final possibility is that employees with present-biased preferences may procrastinate over the decision to change from the default assignment, repeatedly postponing today what they believe they will do tomorrow (O’Donoghue and Rabin, 1999; Carroll et al., 2009).

To differentiate between these mechanisms, we randomly assigned three additional experimental interventions, conducted a series of behavioral games to elicit employees' time preferences, and asked a battery of pointed questions in our panel surveys. Below, we discuss the extent to which the empirical evidence supports each potential mechanism.

\subsection{Endorsement effects}

A priori, we do not think our context is one in which employer endorsement effects are highly relevant. The nature of the individual randomization, whereby each employee knew he or she had an equal chance to be given a $0 \%$ or $5 \%$ default contribution rate, largely eliminates the potential that employees would perceive that they were given a default rate for any reason other than random chance. ${ }^{28}$

Further evidence of this lack of perceived endorsement can be seen in the fact that only a few employees actively decided to switch to a $5 \%$ contribution rate, which was one of the two rates "endorsed" by the employer. This is most evident in the right-most panel of Figure 2. There, we see that among the population of employees offered $50 \%$ matching incentives, a majority of those initially assigned a default contribution rate of $0 \%$ (the peach colored bars) chose to contribute. However, only one employee increased his contribution rate to the "endorsed" level of 5\%; the vast majority instead chose to opt in at $10 \%$ (which was not a default rate).

Qualitatively too, we found no evidence of a perceived endorsement effect. In focus groups, employees expressed gratitude and surprise at observing the truly random assignment of incentives, since past promotions and bonuses had created an expectation of favoritism. When we asked employees who remained at their default why they did not change their contribution rate, none of the employees mentioned employer endorsement, or any factor

\footnotetext{
${ }^{28}$ Specifically, all employees were informed during the mandatory training sessions that both their matching rate and initial contribution rate would be randomly assigned by the research team. The HR staff carefully explained that matching rates (represented by the three M-Pasandaz plans: White, Blue, and Red) could not be changed, but that the initial contribution rate could be changed at any time by contacting Human Resources. And at the end of each training, each employee was provided a personalized assignment card with his or her name and position, matching plan assignment, initial contribution assignment, and phone number for HR. These personalized cards further reinforced that both matching rate and initial contribution rates were being randomly assigned, and that employees were free to change the contribution rate.
} 
involving their employer, as influencing their decision. ${ }^{29}$ Thus, while endorsement effects are undoubtedly consequential in other settings, we believe that the employees in our study did not perceive such a recommendation from the employer.

\subsection{Mechanical frictions}

We similarly find it unlikely that the default effects were driven by superficial transaction costs involved in switching, such as confusion about how the savings account works, ambiguity about how to switch, or mechanical difficulties in executing a switch. ${ }^{30}$ Roshan went to great lengths to train all employees on the M-Pasandaz account, and each employee was sent a monthly text message on payday to indicate how much of their salary was being direct deposited into their normal M-Paisa account and how much was being put into M-Pasandaz. In follow-up surveys, we also find strong evidence that most employees understood their plan type and understood what was required to change their contribution rate. ${ }^{31}$ We emphasize that this feature of our setting is not particularly novel; switching contributions in many settings is straightforward.

\subsection{Inattention}

Looking closely at Figure 1, there is some evidence that employees may have initially been unaware of their default assignment. Specifically, we observe a modest increase in switches on January 23rd, the day after the first payday. Some of these employees likely received a paycheck that was different from what they expected, and this led them to switch. Subsequently, however, we see no more payday effects (row 4 of Table 4), and by February 28, virtually all switching had ceased. Thus, starting in March 2015, we conducted two experimental interventions to see if increasing the salience of the default assignment would induce employees to change their contribution rate.

\footnotetext{
${ }^{29}$ Specifically, two months after the product launch, we randomly surveyed half of employees about reasons for changing or not changing their contributions $(N=428)$. None of those surveyed mentioned factors involving the employer; rather, the most common reasons for not changing included (i) the inability to save, (ii) not wanting to participate, and (iii) satisfaction with the default.

${ }^{30}$ Prior research on defaults similarly regards such mechanical frictions as an unlikely source of default effects. For instance, DellaVigna (2009) estimates that a worker with a salary of $\$ 40,000$ and a $50 \%$ match rate would forgo $\$ 1,200$ in matching incentives by remaining at the default contribution of $0 \%$. Prima facie, such a large frictional cost seems implausible.

${ }^{31}$ For instance, 285 of 295 (97\%) of employees reached for the financial consultation were fully aware of their match rate and their contribution rate. Similarly, in a phone-based survey taken at midline, $87 \%$ of employees reported fully understanding how the M-Pasandaz product worked, more than $90 \%$ correctly identified their plan assignment, and over $70 \%$ knew that they could change their contribution rate by calling the human resources department.
} 
The first "intervention" was simply a series of monthly phone surveys, in which we asked employees questions about their financial behaviors as well as their understanding of the M-Pasandaz account. While the primary function of these interviews was to collect panel data on employee activities that could not be inferred from the administrative records, we also suspected that the survey itself might impact employee behavior by increasing their awareness of M-Pasandaz and the salience of their financial decisions (cf. Zwane et al., 2011). Panel phone surveys were conducted with a randomly selected half of all employees.

The second intervention was designed to increase awareness and salience by reminding employees how to switch their contribution rate. The treatment consisted of a series of text messages, sent roughly at the halfway point of the study, which reminded the employee of his or her current M-Pasandaz contribution rate, as well as the phone number to call in order to change that rate. These messages were sent in English, Dari, and Pashto, and came from an official Roshan phone number. Messages were sent to a random subset of employees, and were tailored to the current status of the employee. For instance, an example message read, "M-Pasandaz Reminder: Next payday, $5 \%$ of your salary will be deposited in your M-Pasandaz account. If you want to change your contribution, call 079999-3708" (Appendix Figure A2).

Neither of these interventions that were designed to increase the salience of M-Pasandaz had much impact on employee switching behavior. This is visibly apparent in Figure 1 (grey and blue shaded regions), is tabulated in Table 4, and is estimated in the regression results shown in Appendix Table A13. We thus conclude that, after the initial one-month period during which roughly one third of employees switched into a non-default contribution rate, the remaining default effect was not driven by limited attention on the part of the employee. As we discuss below, we believe this is partially due to the fact that many employees appear to be unable to determine what their optimal contribution should be. This stands in contrast to other settings, such as commitment and group savings (Karlan et al., 2016b; Kast et al., 2016), where subjects understand their preferred course of action but need nudges to behave consistently with those preferences.

\subsection{Present Bias and Cognitive costs}

An important insight from O'Donoghue and Rabin (1999) is that when an action involves immediate costs (such as the cognitive cost of determining how much to save) and delayed benefits (such as the payout from M-Pasandaz), then naïve present-biased individuals are likely to procrastinate. Appendix B develops a simple model to situate this insight in our setting, focusing on how present bias might cause individuals to remain at their default 
assignment.

Utility is modeled as:

$$
U^{t}(\tau)= \begin{cases}\beta v_{\tau}-c_{\tau} & \text { if } \tau=t \\ \beta v_{\tau}-\beta c_{\tau} & \text { if } \tau>t\end{cases}
$$

where $\tau$ is the period when the switch is made, $v_{\tau}$ is the reward (which is always delayed, even in the sixth month of the program), and $c_{\tau}$ is the cost. This cost includes both the cognitive cost of determining how much to save, mechanical frictions, and any other cost that must be borne to change one's contribution rate. Individuals can either be exponential discounters $(\beta=1)$, present-biased sophisticates $(\beta<1)$ who have correct beliefs, denoted

as $\hat{\beta}$ about their future preferences $(\hat{\beta}=\beta)$, or present-biased naifs, who incorrectly assume they will not be present-biased in the future $(\hat{\beta}=1)$.

The essential implication, as in O'Donoghue and Rabin (1999), is that while a sophisticate correctly knows that her future self is unlikely to participate (given current nonparticipation), a naif incorrectly believes the participation constraint for her future self will be less onerous, because she underestimates the future cost of switching. An additional implication is that individuals who discount the future more heavily, regardless of whether they are present biased, are less likely to participate at all because participation involves immediate costs and delayed rewards.

This section provides three pieces of evidence which favor this characterization of the default effect. First, an experimental measure of present bias strongly predicts remaining at the default. Second, we find that reducing the cognitive cost of working through alternative contribution scenarios leads to significant switching. Finally, we find that employees procrastinate in accepting a financial consultation (which includes an opportunity to switch), and that this is particularly true for present biased employees. We present each of these results in turn.

\subsubsection{Present Bias Predicts Remaining at the Default}

Table 5 examines whether an experimental measure of present bias predicts remaining at the default. We find that our measure of present bias $(\beta)$ robustly predicts whether an employee remains at the default assignment (column 1), even when controlling for a broad range of other factors including the long run discount factor $\delta$, employee salary, gender, a proxy for intelligence based on "cognitive reflection" (Frederick, 2005), financial sophistication (based on whether the employee has a bank account), salary withdrawal habits, and total baseline 
savings (column 2). ${ }^{32}$ The coefficient indicates that moving from the tenth percentile of $\beta$ in our sample $(\beta=0.67)$ to the 90 th percentile $(\beta=1.36)$ is associated with a 9 percentage point decrease in the probability that the employee remains at his default assignment. This result is robust, and persists when we restrict the analysis to employees who are both at their default and who have never made any withdrawals (columns 3 and 4), and when using a simpler, unincentivized measure of present bias collected at baseline (Appendix Table A14). ${ }^{33}$ The heterogeneity by present bias is evident in both the population defaulted in and defaulted out (Table A15). ${ }^{34}$ Finally, in Appendix Table A16, we check for heterogeneity in our main effects on participation by interacting default enrollment with a range of potentially relevant covariates including present bias, cognitive reflection (intelligence), risk preferences, salary, tenure, gender, education level and banked status. We no evidence of heterogeneity by any factor other than present bias.

It is important to distinguish whether the short run or the long run discount factor more robustly predicts remaining at the default. Procrastination, in the O'Donoghue and Rabin (1999) sense, means explicitly failing to accomplish something at the point in time determined in a previous intertemporal plan. An exponential discounter who chooses not to participate does so according to a fully optimal intertemporal plan. A partially naive present-biased individual, by contrast, experiences a preference reversal, and fails to enroll at a point in time when they had previously decided that they would like to do so. While prior work, including Brown et al. (2016) and Brown and Previtero (2014), correlates individuals' tendency to procrastinate with remaining at a default (in their case, staying in a defined benefit, rather than switching to a defined contribution, plan), it does not allow one to distinguish whether this is due to present-bias, or instead a low exponential discount factor.

\footnotetext{
${ }^{32}$ We trim extreme values of the $\beta$ present bias parameter at the $5 \%$ and $95 \%$ level, and extreme outliers of the $\delta$ discount factor parameter, as these appear to reflect respondents who did not understand the exercises.

${ }^{33}$ The measurement protocol for the present bias parameter used in the regression in Table 5 was a modified version of the time-dated price list method proposed by Andreoni et al. (2015) and described in detail in Appendix D.3. This is an incentivized measure based on actual time-dated monetary payments. One drawback of this approach, especially given recent discussions on the elicitation of present-biased preferences using potentially fungible monetary payments (Cubitt and Read, 2007; Chabris et al., 2008; Andreoni and Sprenger, 2012; Augenblick et al., 2015; Carvalho et al., 2014; Andreoni et al., 2016), is the reliance on monetary payments. Since we had a short window of time to survey each employee, and as surveys were conducted at the employee's place of work, we had limited options for measuring present bias. We also felt that the protocol might be more appropriate in our context, given that a substantial share of our sample is credit constrained. The results reported in Appendix Table A14 and described in Appendix D.3 use an unincentivized measure of present bias, and are qualitatively unchanged. An additional advantage of using the baseline measure to test for treatment effect heterogeneity is that it could not have been affected by treatment.

${ }^{34}$ This provides some evidence against alternative explanations that predict a correlation between $\beta$ and being at the default for only one initial assignment. For example, if having a low $\beta$ is a signal of being highly credit constrained in a way that is not captured by salary or education, then $\beta$ would predict remaining at the default only for employees initially assigned to a $0 \%$ contribution.
} 
By contrast, our setting allows for experimental measures of present bias.

\subsubsection{Are Cognitive Costs the Relevant Friction?}

The financial consultation was designed to help reduce the employee's cognitive cost of developing a financial plan. Specifically, we had a representative from Human Resources call a random subset of employees to offer them customized consultations that would answer questions about the M-Pasandaz product, estimate the employee's payouts under different contribution rates, and allow the employee to change his or her contribution rate immediately. The consultation script is provided in Appendix D.1. Relating this exercise to the model, the consultation was intended to reduce $c_{\tau}$ and help identify which of the costs captured by this parameter constrain switching.

As can be seen in Figure 1 (green shaded regions) and Table 4 (row 7), the consultation led a significant number of employees to switch (11.5\%, vs. no more than $3 \%$ for the other interventions). But what about this consultation - which may have affected employees in several ways - was critical to helping employees switch? In our data, we observe employee response to the consultation at six different stages: (i) whether the consultation offer was accepted and scheduled; (ii) whether the employee answered the phone for the scheduled consultation; (iii) whether she requested a review of the product; (iv) whether she requested a review of her current rate; (v) whether she asked the HR officer to walk her through different contribution scenarios; and (vi) whether she wanted to change her contribution. Importantly, every employee was asked at each distinct stage of the consultation whether he or she would like to skip ahead. This provides scope for exploring which element of the consultation is most strongly associated with switching from the default.

The data indicate that it is the penultimate stage of the consultation (providing assistance with financial calculations) that caused employees to switch their contribution. ${ }^{35}$ For instance, Table 6 uses a regression to determine which stage of the consultation most strongly predicts switching. Of the employees who accepted the financial consultations (columns 3 and 4), it is the "Calculation Assistance" stage that leads to significant switching. This effect is unchanged even after controlling for a broad set of employee characteristics (column 4), and is entirely driven by employees increasing their contribution rates after the consultation. None of the other parts of the consultation correlate significantly with switching. While the

\footnotetext{
${ }^{35} 469$ of the 928 employees still active in our study were assigned to be offered a consultation. Of these, 443 employees answered the first call making the initial offer. Of these 443, 327 employees agreed to a full consultation. Of the 327 employees who accepted the consultation, 295 were reached by the second caller offering the consultation. Of the 295 employees who both accepted and who were reached for a consultation, 95 requested assistance with calculating how much money they would earn in different contribution scenarios. 54 employees switched their contribution rate during the consultation (49 switched up and 5 switched down), of which $47(87 \%)$ had requested calculation assistance.
} 
decision to solicit assistance is endogenous, the robustness of this correlation to several variables which should be relevant for the decision to seek calculation assistance (e.g., financial sophistication and salary), provides some indication that the cognitive cost of switching is a meaningful obstacle. This appears to be particularly true for those assigned a positive default rate and still at their default, as in Appendix Table A17. It may be that for these employees, the loss from not switching is smaller, because they are making some positive contribution.

\subsubsection{Take Up of the Consultation and Present Bias}

An employee may not switch their election for many reasons. In developed countries, this is a very broad set including confusion related to tax concerns, asset mixes, finding time to complete the process, and so on. While the range of potential frictions in our setting is different, we were interested in testing whether the time and mental effort involved in switching acted as a key friction driving procrastination.

Thus, in implementing our consultation experiment, we randomly varied whether employees were offered a consultation immediately, or with a week's delay. This experiment was intended to mimic the experimental tests of present bias that require the completion of some costly task either immediately, or with a delay, as implemented in the lab in Augenblick et al. (2015) and the field in Andreoni et al. (2016). More specifically, when employees were offered this consultation, they were either told that the consultation would occur immediately following the scheduling call, or that the consultation would occur roughly one week after the scheduling call. Whether the offer was for a consultation now or later was randomized, in order to experimentally vary each subject's ability to procrastinate over developing a financial plan. Importantly, however, in our setting the costly task used to test for present bias is specifically the friction that is potentially relevant to driving present bias (i.e., the cost and mental effort required to switch elections).

Table 7 reports results from this experiment. The consultations were very popular, with $73 \%$ of employees accepting when offered an immediate consultation and $79 \%$ accepting when offered a consultation with a week delay. This difference, reported in column 1, suggests slightly more demand for consultations offered with a delay, although this difference is not statistically significant (s.e. $=0.047, \mathrm{p}=0.182$ ). The difference increases slightly when controlling for other employee characteristics (column 2: s.e. $=0.048, \mathrm{p}=0.089$ ), which suggests that procrastination over the time and mental effort required to switch elections may be an obstacle to switching elections. Interestingly, estimates reported in column 3 indicate that for employees with $\beta<1$, the difference is 17.7 percentage points, and is significant at conventional levels. In column 4 , we additionally interact a dummy variable equal to one for 
subjects offered the consultation with a week delay with a measure of their long run discount factor (a dummy equal to one when $\delta<1$ ). There is no evidence of heterogeneity along this dimension. ${ }^{36}$ However, the main interaction of interest loses significance after adding a full set of covariates and their interactions with the consult later treatment dummy (column 5: s.e. $=0.094, \mathrm{p}=0.208)$, though the point estimate remains comparable. ${ }^{37}$ Differential response to the consultation, therefore, should be viewed primarily as a corroboration of our experimental measure of present bias $\beta$. Also, while the financial consultation was the most effective approach to induce employees to switch from their default rate, even this very heavy-handed treatment only moves a small fraction of employees. ${ }^{38}$

Relating this observation back to the potential role for (naive) present bias to create default effects, the consultation - and providing assistance with financial math in particularcan be thought of as removing an important cost to switching. Even for naive and severely present-biased individuals, in the model of O'Donoghue and Rabin (1999), completely eliminating transaction costs will eliminate procrastination. This is empirically what we observe. This also carries a policy implication: if welfare is evaluated using long run preferences, one welfare-enhancing way to eliminate procrastination would be to eliminate switching costs. ${ }^{39}$

The evidence presented thus far indicates that present-biased employees are most likely to remain at their default-assigned contribution rate, that present-biased employees are more likely to accept a financial consultation when it is offered with a week delay, and that the financial consultation - which we believe reduced the mental costs faced by employees when deciding to switch — was the lone experimental intervention that induced a significant share of employees to switch. The sum total of this evidence lead us to believe that much of the default effect we observe can be explained by present bias exacerbating the cognitive cost associated with calculating alternative savings scenarios.

\footnotetext{
${ }^{36}$ There is also no evidence of heterogeneity when interacting the delay dummy only with $\delta$.

${ }^{37}$ In Appendix Table A18 we also find negative effects using the unincentivized baseline measure of present bias, but lack statistical power to reject the null hypothesis.

${ }^{38}$ Appendix Table A19 explicitly compares the effect of the financial consultation with the effect of SMS reminders on the employee's decision to switch. While the effect of the text messages is small and statistically indistinguishable from zero, the offer of the financial consultation has a large and significant effect, particularly for subjects still at their default election (Column 2). Within this subsample, the effect of offering a financial consultation was even larger for those subjects who were enrolled by default, i.e., who were assigned a default contribution rate of $5 \%$ (column 3 of Appendix Table A19).

${ }^{39}$ Of course, the finding that financial consultations reduces the default effect is consistent with alternative explanations. For example, it could just be that an extended consultation is the only action that raises the salience of the decision enough to induce switching. However, such an explanation would be hard to reconcile with other survey-based evidence indicating employees were acutely aware of M-Pasandaz activity. Alternatively, the financial consultation may have influenced employees in other ways as well, for instance by providing information that would help the employee choose an optimal contribution rate. This may be a part of the explanation, but outside of the consultation, very few employees took the initiative to consult an HR representative for such advice.
} 


\subsection{Alternative Explanations}

Before concluding, we address three alternative explanations for the results we have presented. The first two concern the possibility that the individual-level randomization of default and matching rates may have caused employees to behave differently than they would have had all employees been assigned the same default contribution rate and matching incentives. The final point we discuss is the possibility that loss aversion, or a related form of reference-dependent preferences, might explain the default effects.

One might be concerned that in our context, employees might behave strategically if they believe their actions can impact future policy decisions made by the firm. However, we believe such strategic behavior to be unlikely for several reasons. First, as noted in Section 4 (Table 2), the default effect persisted even after all employees were standardized onto a single plan, when employees were asked to decide about future contributions to MPasandaz. At this point in the study, there was no scope for strategic behavior. Second, we have presented robust evidence in Section 5.4.1 that a large share of employees are present biased (roughly $41 \%$ have $\beta<1$ ). The sort of strategic behavior we are concerned with would require making a short-run sacrifice to improve the long-run outcome, which is particularly hard to reconcile with the fact that the company has had very high rates of employee churn: roughly $14 \%$ of all employees left the company in the year between our baseline and endline surveys, and two years after the completion of the study, less than $50 \%$ of employees remained active at the company. Third, while such a motivation could help explain the decision not to opt in among employees who didn't get matching contributions, it does not explain why the employees randomly assigned a $5 \%$ rate did not opt out. Finally, we raised this concern with our partners at Roshan early in the planning stages of the project, and they considered it a highly implausible proposition. Their perception was that most employees lived paycheck-to-paycheck, and would therefore be unlikely to intentionally forgo salary (or matching incentives) to influence policy. Even in the relatively short 6-month window, an employee's contribution decisions had major economic consequences.

Related, it is possible that employees could base their contribution decisions on the plan they were assigned relative to their peers (as in Duflo and Saez, 2003; Banerjee et al., 2013; Bursztyn et al., 2014; Beshears et al., 2015), and that they might make different decisions if all employees were assigned a uniform plan. For instance, an employee with no matching incentives and a default contribution rate of $0 \%$ might choose not to increase his contribution because he feels he got an inferior plan relative to his coworkers who receive a $50 \%$ match on contributions. We were concerned about this possibility from the project's inception, and therefore worked closely with our partners at Roshan to minimize the possibility that employees would react to their co-worker's assignment. Specifically, the M-Pasandaz program 
was introduced to employees during hour-long training sessions that emphasized the private nature of the individually-assigned plan and the importance that each employee make a personal decision about his or her preferred contribution rate. Great care was taken to explain that the study was being run by academic researchers, and that each employee had an equal chance of being assigned to each of the different plans. Plan details were handed out on written information cards, and employees were instructed not to ask their coworkers about the details of their plans. While we do not believe these efforts eliminated information sharing or possible feelings of jealousy, every effort was made to encourage each employee to make a personal financial decision. ${ }^{40}$

A different sort of strategic behavior may arise if employees believe that their M-Pasandaz decisions send a signal to their employer. For example, employees may hope to signal something positive about themselves by saving in their employer-provided savings account. Such an explanation predicts an asymmetry of the default effect, where employees should either remain at their default or increase their saving. However, as can be seen in Figure 2, default effects exist at all levels of matching incentives and at both default rates, and a substantial share of employees switch their contribution to zero, even when the employer is providing a match.

Finally, we address the possibility that the default effects we observe are due in part to loss aversion. While this explanation features less prominently in the literature - see recent reviews by Madrian (2013), Beshears et al. (2009), and DellaVigna (2009) - it is conceivable that the default creates a reference point and employees experience greater disutility from giving up some benefit than the utility they would receive from getting it (Kahneman et al., 1991; Tversky and Kahneman, 1991). In our setting, reference points could be relevant in four ways. First, employees who are assigned a default contribution rate of zero may not increase their contribution because their reference point is their pre-experiment level of consumption. However, this idea is difficult to reconcile with the substantial default effects we observe for those employees who are initially assigned a default contribution rate of $5 \%$ and who receive no matching incentive. This characterization predicts that these employees should withdraw. However, as can be seen in the first panel of Figure 2, 36\% of employees with no matching incentives and a default contribution rate of $5 \%$ still contribute $5 \%$ at the end of the study (a portion that is almost identical to the portion of employees assigned a default contribution rate of $5 \%$ who receive $25 \%$ or $50 \%$ matching incentives). A second possibility is that employees exhibit reference dependence with regard to the amount of the employer

\footnotetext{
${ }^{40}$ In results available upon request, we also test explicitly for evidence of peer effects, looking for evidence that employees are more likely to participate if they had a larger fraction of their social network randomly defaulted in to savings. In short, we find no evidence of such effects.
} 
match that they expect to receive. This, also, is challenging to reconcile with the large default effects we observe for employees who do not receive any employer match. A third explanation is that employees base their reference point on the balance in their M-Pasandaz account. However, the design of the account - which ample evidence suggests that employees fully understood - does not penalize employees for changing contributions. All accrued benefits are retained regardless of contribution rate; the only action that causes employees to forfeit matching incentives is if they make an early withdrawal from their account. If an employee provided with a positive balance values it more than an employee provided no balance, then it is difficult to understand why employees assigned to $5 \%$ would not be more likely to switch up (the opposite of what we observe in the data). A final explanation is that employees simultaneously set reference points in both the consumption and savings domains as soon as they receive their random assignment, and their utility functions are such that any departure would create greater losses in one domain than the gains in the other. This would need to be true independent of the size of the matching incentive. In addition, reference points would need to be set shortly after random assignment. ${ }^{41}$ While the wealth of evidence affirmatively pointing to present bias leads us to believe that is a more likely candidate mechanism behind the default effects we observe, we cannot conclusively rule out this particular form of loss aversion with our data.

\section{Conclusions}

Exploiting the carefully planned launch of a new phone-based savings account, we evaluate the role of defaults and financial incentives on the savings decisions of 949 Afghan employees. Both effects are substantial, and together help employees accumulate meaningful savings, with the average participating employee accumulating an M-Pasandaz balance of 12,615 Afghanis, equal to $38.9 \%$ of the average monthly salary, over the initial 6-month evaluation period. Employees receiving no matching incentive accumulated about $18 \%$ of a month's salary, suggesting automatic enrollment is also potentially cost-effective. In exit interviews with the subjects in our study, we were struck by the extent to which employees embraced the new technology. One employee told us that on payday, all of the neighborhood clothing

\footnotetext{
${ }^{41}$ At the time of writing, understanding the speed with which reference points adapt is an active area of research. For example, in Köszegi and Rabin's (2006) original paper, the authors point out: "Our theory posits that preferences depend on lagged expectations, rather than expectations contemporaneous with the time of consumption. This does not assume that beliefs are slow to adjust to new information or that people are unaware of the choices that they have just made - but that preferences do not instantaneously change when beliefs do. When somebody finds out 5 minutes ahead of time that she will for sure not receive a long-expected $\$ 100$, she would presumably immediately adjust her expectations to the new situation, but she will still 5 minutes later assess not getting the money as a loss."
} 
and cosmetics vendors would be excited to see her because they knew she was out to spend a good chunk of her paycheck. M-Pasandaz helped her precommit to cutting down on that spending, and she was happy with that change.

This paper also adds nuance to our understanding of why defaults affect behavior. In particular, our results support the notion that default effects exist in part because presentbiased employees procrastinate over the task of making a non-default election. Here too the regression results resonate with stories on the ground: one employee in the default-in group, when forced to make the active savings decision at the conclusion of our study, reported that he had been meaning to change his rate for each of the prior six months, but had never managed to find the time to think through how a change would impact his monthly budget.

A key benefit to our study was that our implementing partner committed to a close collaboration from the outset. We believe this example is potentially instructive for models of engagement where these questions are most often studied: in firms in developed countries. Our partner allowed us to work on the design and experimental implementation of the product and to conduct a series of experiments and longitudinal surveys with their employees. This added value for the firm. It provided them evidence on whether the default works, the matching incentive they would need to provide to achieve a similar effect, what matching levels they should consider, and, most importantly, whether and how this product affected the lives of their employees. In addition, because we worked with the phone company, this provided them evidence to determine whether they should add M-Pasandaz to their set of commercial products, which they have done.

Nonetheless, we are still some distance from fully understanding how to characterize the inertia that results from defaults, and in developed countries additional complications arise for instance, regarding taxes and asset mixes. In our view, comparable projects in developed countries could shed substantial insight on key policy questions related to savings.

Indeed, in rich countries, the use of defaults to encourage retirement savings provides, perhaps, the canonical example of applying behavioral insights to policy design. Appropriately, most academic research on the subject uses data from these settings; this is by and large where these programs exist. However, a growing body of research emphasizes the potential for behavioral departures from rationality to be even more damaging in developing countries. The world's poor may face a much greater scarcity of mental resources to think carefully about the long run; they may be credit and resource constrained in ways that exacerbate behavioral tendencies; they often face worse decision environments; and they typically benefit from far fewer institutions for financial protection.

Separately, in our context, Afghanistan, the government faces a rapidly growing financial burden in the form of pension commitments for public sector workers, which is forecasted 
to grow to as much as one-third of the annual budget in coming decades. It may be that transitioning toward automatic enrollment in defined contribution schemes, as has happened in developed countries, could begin to alleviate some of this burden. Our hope in designing and evaluating this product is to provide an example of how policies and innovations designed to overcome these obstacles in wealthy nations can be applied globally. 


\section{Tables and Figures}

Figure 1: Switching behavior over time

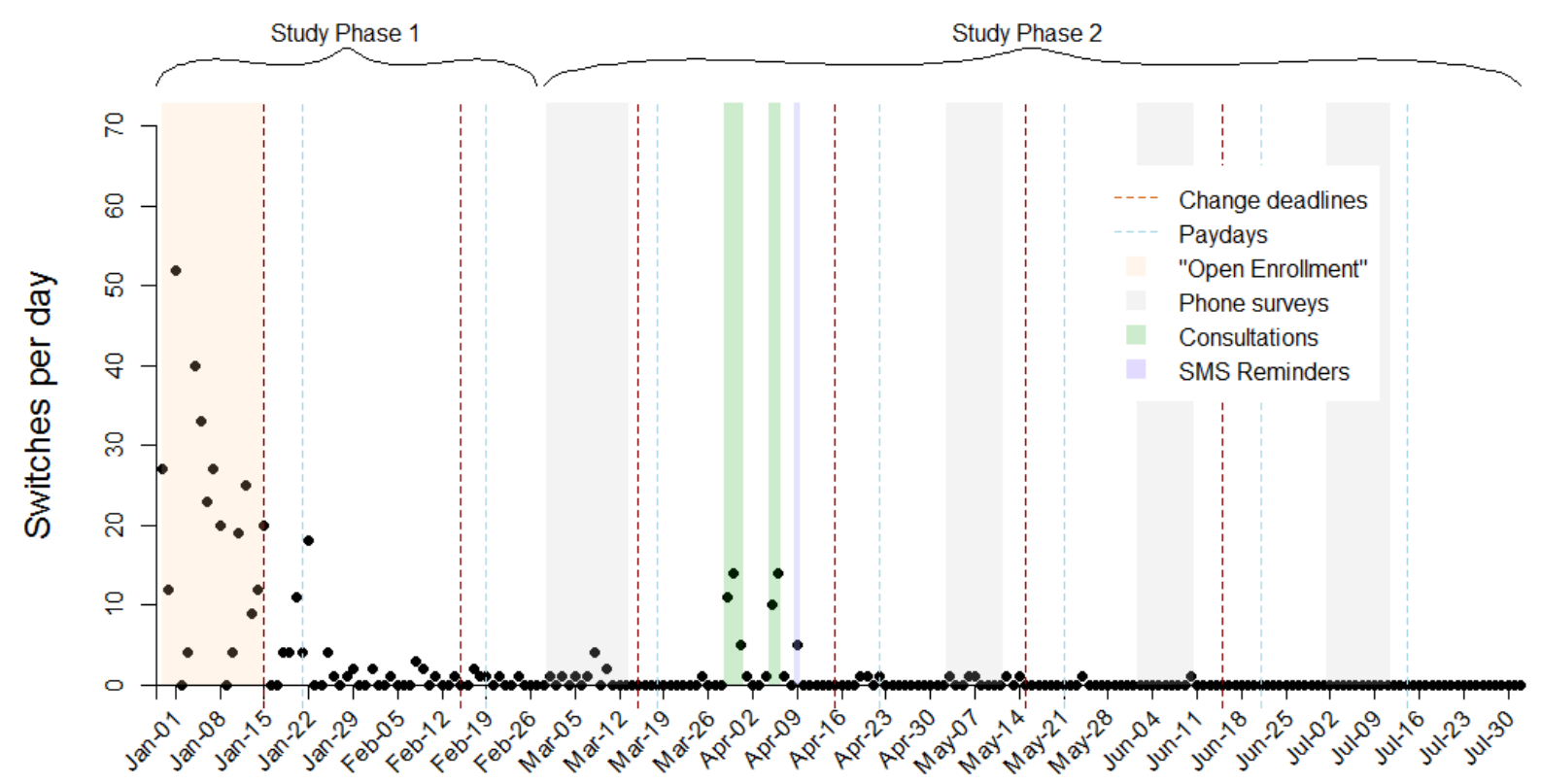

Notes: Black dots indicate the number of employees calling in, on each day of the study, to change their contribution rate. Dashed vertical lines indicate the days when employees receive their salary (dashed blue line), and the deadline to make changes for that pay cycle (dashed red line). Shaded regions indicate the experimental interventions of our study. 
Figure 2: Employee contributions: Initial assignments and final contribution rates
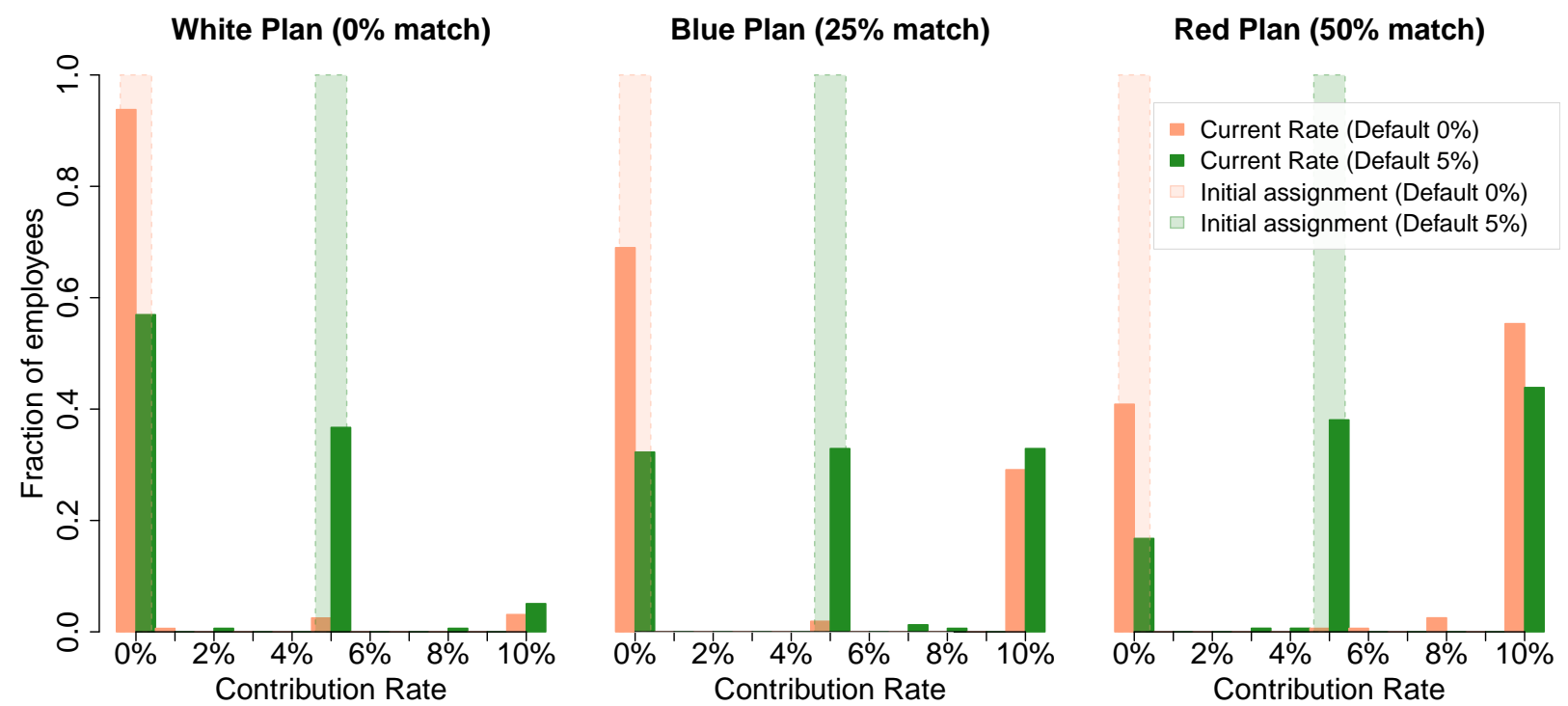

Notes: Distribution of final M-Pasandaz contribution levels in July 2015, as a percentage of monthly salary. Individuals were randomized into either a default $0 \%$ contribution (peach bars, $\mathrm{N}=478$ ) or a default $5 \%$ contribution (green bars, $\mathrm{N}=471$ ). Individuals were further randomized into three different incentive rates: White (0\% match, $\mathrm{N}=319)$, Blue (25\% match, $\mathrm{N}=316)$ and Red (50\% match, $\mathrm{N}=314)$. Semi-transparent bars indicate the original assigned contribution rate, solid bars indicate final contribution rate. 


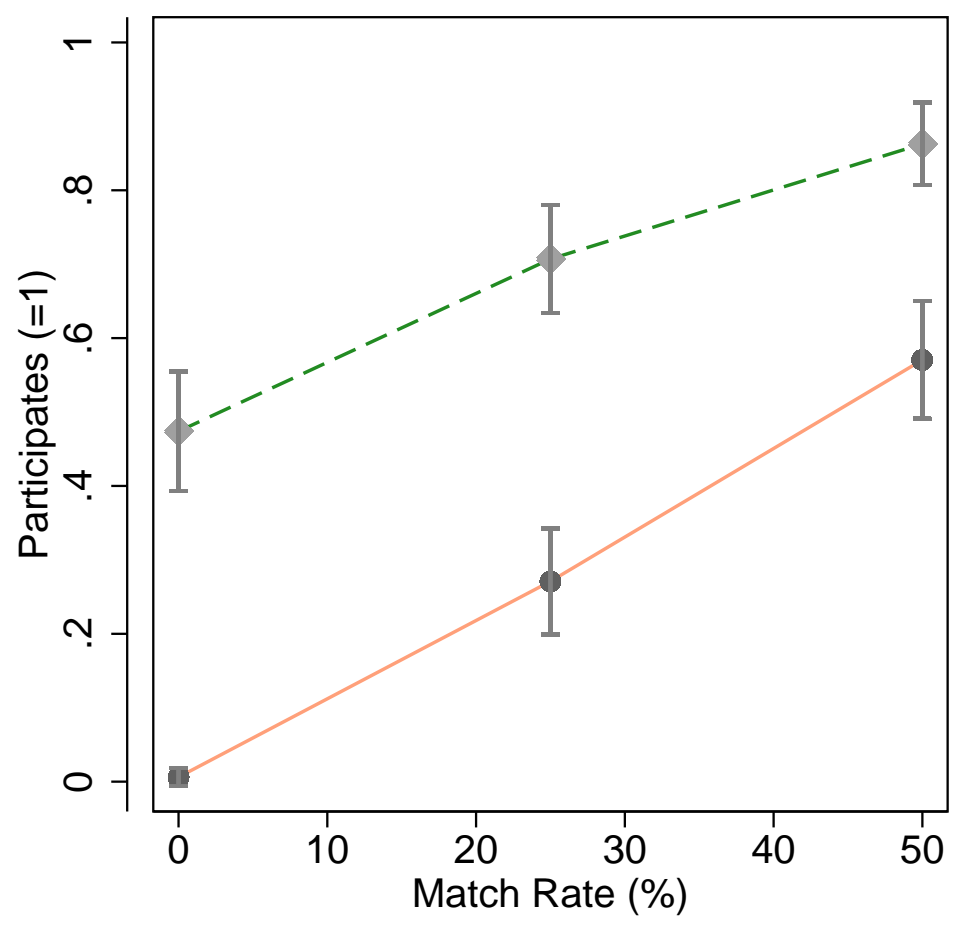

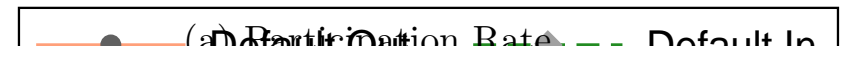

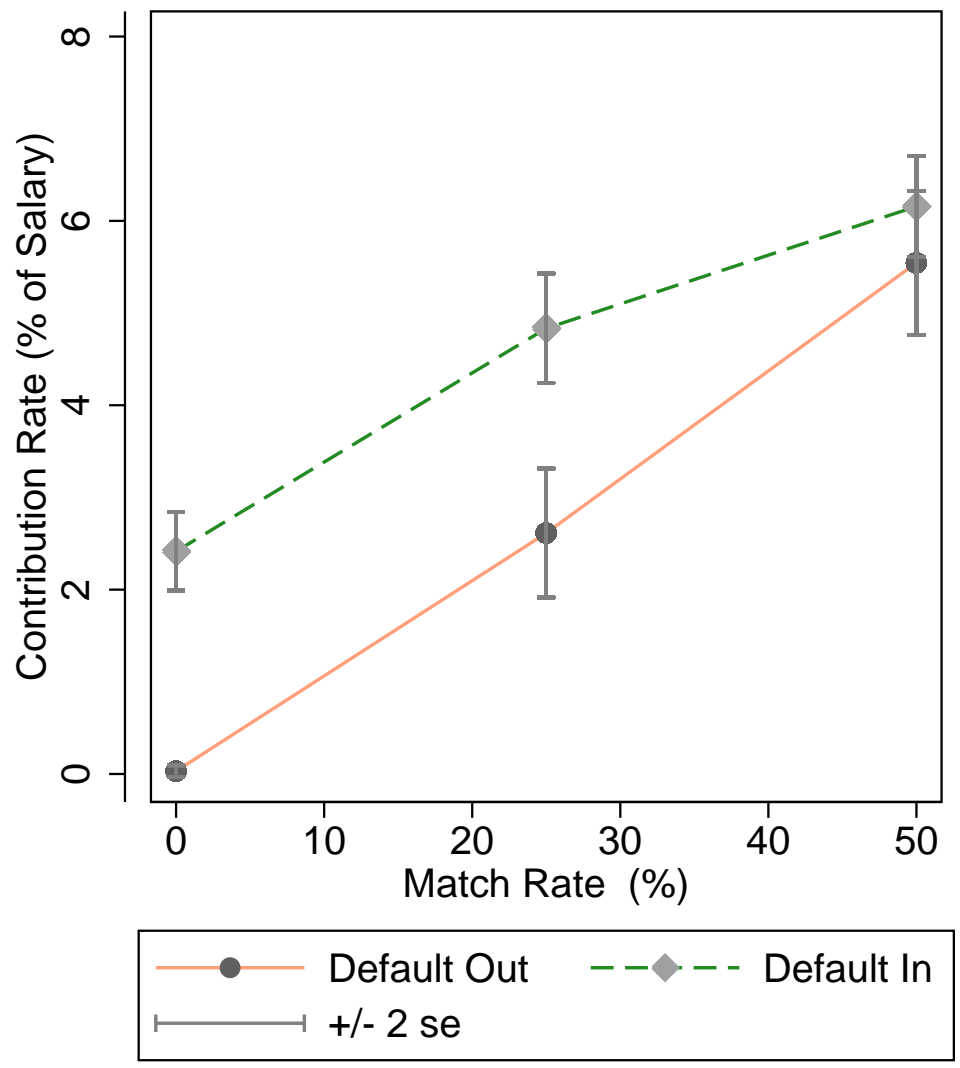

(b) Contribution Rate

Figure 3: Effect of automatic enrollment and matching contributions on (a) participation rates (non-zero contributions), measured on February 28, 2015, following the first two paydays but prior to the rollout of phone surveys or secondary interventions; and (b) contribution rates, as a fraction of the employee's total salary, measured on February 28, 2015. 
Figure 4: M-Pasandaz participation and balance during and after RCT

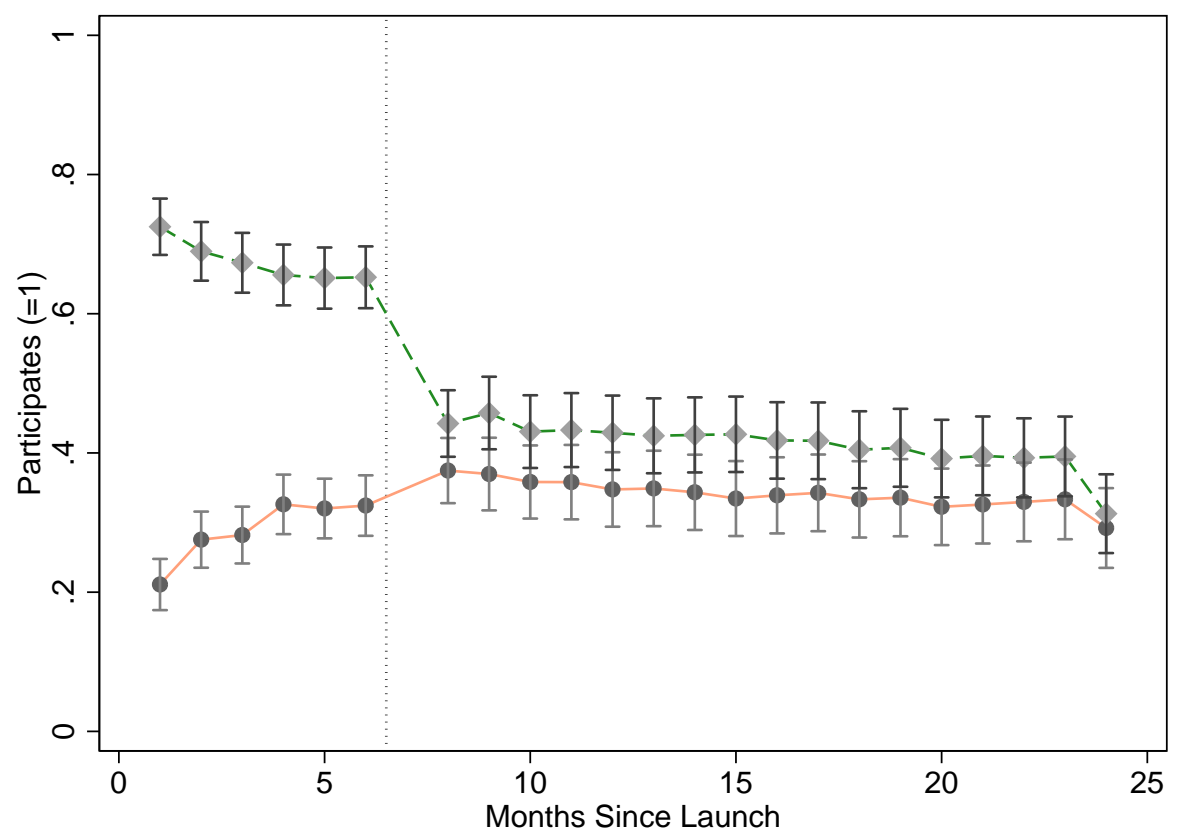

(a) Average Participation Rate (administrative data)

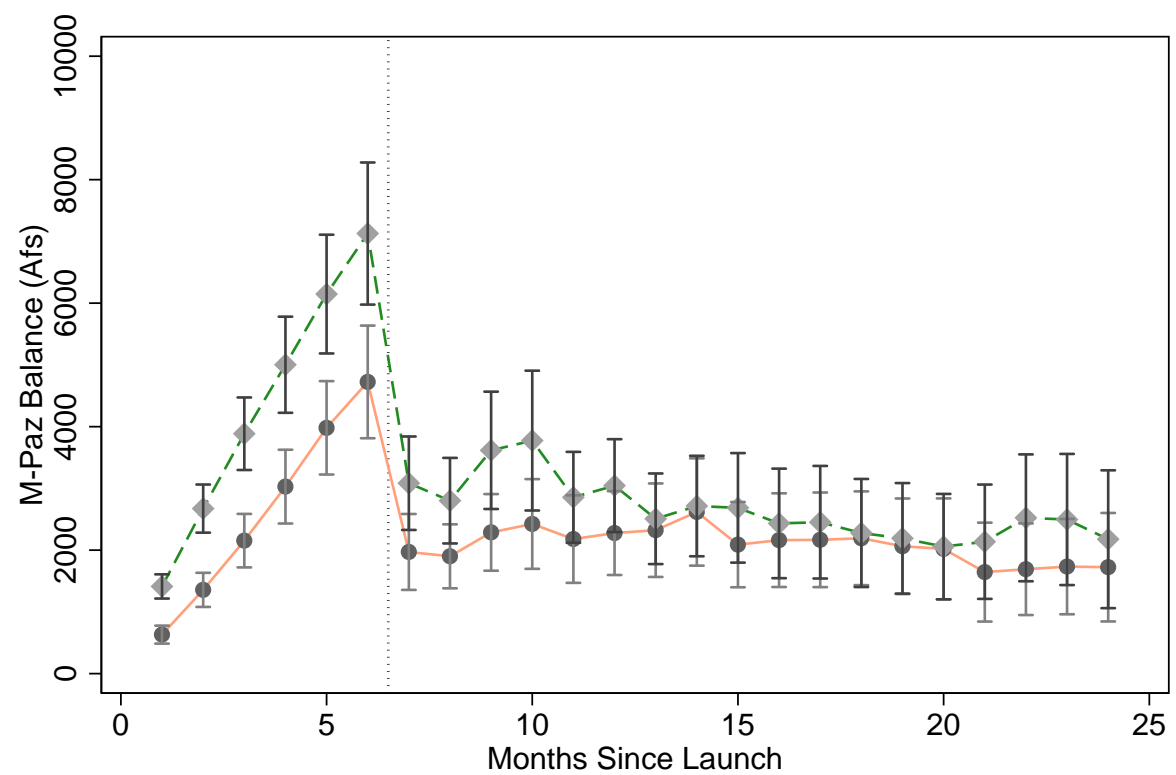

$\longrightarrow$ Default Out ---- Default In $\longmapsto+$ - 2 se

(b) Average M-Pasandaz Balance (administrative data)

Notes: The randomized trial ran from January 2015 (month 1) until July 2015 (month 7), when bonus payments were paid. Average participation and balance are calculated separately for employees assigned a default contribution of $0 \%$ of their salary (Default Out) and those assigned a default contribution of $5 \%$. Participation is coded as missing in July 2015 as no automatic contributions were made while endline surveys took place; deposits resumed in August 2015 based on active savings decisions in the endline survey (see text for details). 
Table 1: The Default Effect on Participation and Contributions

\begin{tabular}{|c|c|c|c|c|}
\hline & (1) & $(2)$ & $(3)$ & $(4)$ \\
\hline \multicolumn{5}{|c|}{ Panel $A$. Dependent Variable $=$ Participates (non-zero contribution rate } \\
\hline \multirow[t]{2}{*}{ Default In $(=1)$} & 0.40 & 0.47 & 0.44 & 0.29 \\
\hline & $(0.03)$ & $(0.04)$ & $(0.05)$ & $(0.05)$ \\
\hline \multirow[t]{2}{*}{ Constant } & 0.28 & 0.01 & 0.27 & 0.57 \\
\hline & $(0.02)$ & $(0.01)$ & $(0.04)$ & $(0.04)$ \\
\hline Sample & Complete & $0 \%$ Match & $25 \%$ Match & $50 \%$ Match \\
\hline \# Observations & 936 & 315 & 312 & 309 \\
\hline R-Squared & 0.161 & 0.304 & 0.190 & 0.105 \\
\hline \multicolumn{5}{|c|}{ Panel B. Dependent Variable $=$ Contribution Rate ( $\%$ of Salary) } \\
\hline \multirow[t]{2}{*}{ Default In $(=1)$} & 1.77 & 2.38 & 2.22 & 0.61 \\
\hline & $(0.26)$ & $(0.21)$ & $(0.46)$ & $(0.48)$ \\
\hline \multirow[t]{2}{*}{ Constant } & 2.70 & 0.03 & 2.61 & 5.54 \\
\hline & $(0.20)$ & $(0.03)$ & $(0.35)$ & $(0.39)$ \\
\hline Sample & Complete & $0 \%$ Match & $25 \%$ Match & $50 \%$ Match \\
\hline \# Observations & 936 & 315 & 312 & 309 \\
\hline R-Squared & 0.046 & 0.293 & 0.071 & 0.005 \\
\hline \multicolumn{5}{|c|}{ Panel C. Dependent Variable $=$ Total M-Pasandaz Contributions (Afs) } \\
\hline \multirow[t]{2}{*}{ Default In $(=1)$} & 2426.40 & 2244.30 & 2996.73 & 2052.39 \\
\hline & $(750.24)$ & $(656.96)$ & $(1335.00)$ & $(1567.93)$ \\
\hline \multirow[t]{2}{*}{ Constant } & 4724.44 & 416.75 & 5015.57 & 8797.03 \\
\hline & $(465.52)$ & $(157.60)$ & $(802.11)$ & $(1040.07)$ \\
\hline Sample & Complete & 0\% Match & $25 \%$ Match & $50 \%$ Match \\
\hline \# Observations & 949 & 319 & 316 & 314 \\
\hline R-Squared & 0.011 & 0.036 & 0.016 & 0.005 \\
\hline
\end{tabular}

Notes: Dependent variable in top panel, Participates $(=1)$, is a binary variable that equals one if the contribution rate is greater than zero, and dependent variable in middle panel, Contribution Rate (\% of Salary), is the monthy contribution rate into M-Pasandaz as a percent of total salary. Participates and Contribution Rate reflect values observed as of February 28, 2015, following the first two paydays but prior to the rollout of phone surveys or secondary interventions. Dependent variable in third panel is total contributions made by the employee to M-Pasandaz, in Afghanis, as observed in administrative data. Value reflects total contributions net of withdrawals as of July 15, 2015, just prior to the disbursement of matching incentives. Value does not include matching contributions made by the employer. Robust standard errors reported in parentheses. 
Table 2: The Default Effect on Active Decision at Trial End

\begin{tabular}{lcccc}
\hline & \multicolumn{4}{c}{ Continued M-Pasandaz After Program (=1) } \\
& $(1)$ & $(2)$ & $(3)$ & $(4)$ \\
\hline Default In (=1) & 0.10 & 0.16 & 0.07 & 0.08 \\
& $(0.03)$ & $(0.06)$ & $(0.06)$ & $(0.06)$ \\
Constant & 0.40 & 0.34 & 0.39 & 0.48 \\
& $(0.02)$ & $(0.04)$ & $(0.04)$ & $(0.04)$ \\
Sample & Complete & $0 \%$ Match & $25 \%$ Match & $50 \%$ Match \\
\# Observations & 811 & 272 & 277 & 262 \\
R-Squared & 0.011 & 0.025 & 0.005 & 0.007 \\
\hline
\end{tabular}

Notes: Dependent variable is a binary indicator that equals one if the employee made an active decision to continued contributing to the M-Pasandaz after the 6 month study ended with no matching incentives offered. Robust standard errors reported in parentheses. 
Table 3: The Default Effect on Savings Behavior, Financial Security, and Well-Being

\begin{tabular}{|c|c|c|c|c|c|}
\hline Outcome: & $\begin{array}{c}\text { Control } \\
\text { Mean }\end{array}$ & $\begin{array}{c}\text { Default } \\
\text { Effect }\end{array}$ & $\begin{array}{c}\text { Naive } \\
\text { p-Value }\end{array}$ & $\begin{array}{l}\text { List et al } \\
\text { p-Value }\end{array}$ & $\begin{array}{c}\text { Bonferonni } \\
\text { p-Value }\end{array}$ \\
\hline \multicolumn{6}{|l|}{ Panel A: Composite Indices } \\
\hline Importance of Saving Index & -0.004 & 0.142 & 0.002 & 0.012 & 0.013 \\
\hline Financial Security Index & 0.002 & 0.111 & 0.005 & 0.019 & 0.033 \\
\hline Well-Being Index & -0.001 & 0.025 & 0.512 & 0.757 & 1.000 \\
\hline \multicolumn{6}{|l|}{ Panel B: Importance of Saving Index Variables: } \\
\hline Savings is Important $(=1)$ & 0.954 & 0.004 & 0.756 & 0.767 & 1.000 \\
\hline Attempts to Save Each Month $(=1)$ & 0.627 & 0.074 & 0.026 & 0.051 & 0.078 \\
\hline M-Paz Changed Desire to Save & 0.539 & 0.092 & 0.009 & 0.032 & 0.034 \\
\hline \multicolumn{6}{|l|}{ Panel C: Financial Security Index Variables: } \\
\hline Not Financially Constrained $(=1)$ & 0.639 & 0.073 & 0.026 & 0.100 & 0.128 \\
\hline Confident Meeting Current Fin. Obligations $(=1)$ & 0.929 & 0.036 & 0.020 & 0.091 & 0.097 \\
\hline Confident Meeting Future Fin. Obligations (=1) & 0.798 & 0.023 & 0.412 & 0.663 & 1.000 \\
\hline Will Retire Someday $(=1)$ & 0.373 & 0.001 & 0.971 & 0.973 & 1.000 \\
\hline Financial Satisfaction $(1-10)$ & 6.443 & 0.323 & 0.027 & 0.083 & 0.142 \\
\hline \multicolumn{6}{|l|}{ Panel D: Well-Being Index Variables: } \\
\hline Nights No One Without Food & 6.616 & 0.042 & 0.518 & 0.892 & 1.000 \\
\hline Happy Overall $(=1)$ & 0.932 & 0.003 & 0.853 & 0.851 & 1.000 \\
\hline Life Satisfaction $(1-10)$ & 7.863 & 0.036 & 0.810 & 0.965 & 1.000 \\
\hline Good Physical Health $(=1)$ & 0.768 & 0.072 & 0.010 & 0.051 & 0.055 \\
\hline Healthy Last Three Months $(=1)$ & 0.968 & 0.010 & 0.441 & 0.902 & 1.000 \\
\hline \multicolumn{6}{|l|}{ Panel E: Other Variables: } \\
\hline Satisfied at Roshan $(=1)$ & 0.771 & 0.017 & 0.548 & 0.799 & 1 \\
\hline Left Roshan $(=1)$ & 0.142 & 0.004 & 0.850 & 0.855 & 1 \\
\hline
\end{tabular}

Notes: This table reports the effects of defaulting employees into the M-Pasandaz automatic salary withdrawal savings account. Indices are created as the covariance-weighted sum of z-scores of the underlying variables, following the technique described in Anderson (2008). List et al. (2016) and Bonferonni P-values are calculated controlling for the Family Wise Error Rate for the first five variables reported in the table, and then for each set of variables underlying the index respectively. Full text of the survey questions used to create indices is available in Appendix D.2. 
Table 4: Contribution rate switches, by default contribution and matching incentives

\begin{tabular}{|c|c|c|c|c|c|c|c|c|c|}
\hline & \multirow[b]{2}{*}{$N$} & \multirow[b]{2}{*}{ Total } & \multirow[b]{2}{*}{$\%$} & \multicolumn{3}{|c|}{ Default Out } & \multicolumn{3}{|c|}{ Default In } \\
\hline & & & & $0 \%$ & $25 \%$ & $50 \%$ & $0 \%$ & $25 \%$ & $50 \%$ \\
\hline Changed In Open Enrollment & 326 & 943 & 34.57 & 0 & 32 & 68 & 75 & 80 & 71 \\
\hline Changed After 1st Payday & 22 & 943 & 2.33 & 0 & 7 & 4 & 3 & 6 & 2 \\
\hline Changed By February 28th & 385 & 936 & 41.13 & 1 & 42 & 89 & 84 & 89 & 80 \\
\hline Changed After Other Payday & 2 & 936 & 0.21 & 0 & 1 & 0 & 0 & 0 & 1 \\
\hline Changed After Survey & 3 & 441 & 0.68 & 0 & 0 & 0 & 1 & 2 & 0 \\
\hline Changed After SMS & 6 & 224 & 2.68 & 0 & 0 & 2 & 2 & 2 & 0 \\
\hline Changed After Consultation & 54 & 469 & 11.51 & 10 & 7 & 6 & 8 & 11 & 12 \\
\hline Changed More Than Once & 14 & 949 & 1.48 & 2 & 2 & 5 & 2 & 3 & 0 \\
\hline Ever Changed Contribution & 459 & 949 & 48.37 & 11 & 49 & 96 & 100 & 107 & 96 \\
\hline Never Changed Contribution & 456 & 890 & 51.24 & 142 & 101 & 57 & 51 & 50 & 55 \\
\hline Observations & & & & 161 & 158 & 159 & 158 & 158 & 155 \\
\hline
\end{tabular}

Notes: " $N$ " indicates the number of unique employees who changed their contribution rate as a result of the action. "Total" indicates the number of participants that were treated by the specified treatment and is adjusted to account for attrition at the time of calculation. For example, "Ever Changed Contribution" row includes all 949 employees, while "Never Changed Contribution" includes only 890 employees still present in final month of study. Payday, Survey, SMS and Consultation switches are recorded if corresponding to the day of the intervention or the day immediately afterwards. 
Table 5: Present Bias and Contribution Changes

\begin{tabular}{|c|c|c|c|c|}
\hline \multirow[t]{2}{*}{ Dependent Variable: } & \multicolumn{2}{|c|}{ Still at Default on February 28} & \multicolumn{2}{|c|}{$\begin{array}{c}\text { Still at Default and } \\
\text { No Withdrawal on Feb. } 28\end{array}$} \\
\hline & (1) & $(2)$ & (3) & (4) \\
\hline Present Bias Parameter $(\beta)$ & $\begin{array}{l}-0.132 \\
(0.051)\end{array}$ & $\begin{array}{l}-0.132 \\
(0.052)\end{array}$ & $\begin{array}{l}-0.088 \\
(0.052)\end{array}$ & $\begin{array}{l}-0.089 \\
(0.052)\end{array}$ \\
\hline Long Run Discount Factor $(\delta)$ & & $\begin{array}{c}0.028 \\
(0.053)\end{array}$ & & $\begin{array}{l}0.029 \\
(0.054)\end{array}$ \\
\hline Cognitive Reflection Test (0-3) & & $\begin{array}{l}-0.060 \\
(0.025)\end{array}$ & & $\begin{array}{l}-0.069 \\
(0.025)\end{array}$ \\
\hline Risk Preference (1-10) & & $\begin{array}{c}0.008 \\
(0.006)\end{array}$ & & $\begin{array}{c}0.009 \\
(0.006)\end{array}$ \\
\hline Salary (1000 Afs) & & $\begin{array}{l}0.000 \\
(0.001)\end{array}$ & & $\begin{array}{l}0.000 \\
(0.001)\end{array}$ \\
\hline Tenure at Roshan (Years) & & $\begin{array}{l}-0.009 \\
(0.007)\end{array}$ & & $\begin{array}{l}-0.004 \\
(0.007)\end{array}$ \\
\hline Male $(=1)$ & & $\begin{array}{l}0.055 \\
(0.055)\end{array}$ & & $\begin{array}{l}0.055 \\
(0.055)\end{array}$ \\
\hline Education Level & & $\begin{array}{l}-0.002 \\
(0.018)\end{array}$ & & $\begin{array}{l}-0.005 \\
(0.018)\end{array}$ \\
\hline Uses a Bank Account (=1) & & $\begin{array}{l}-0.041 \\
(0.041)\end{array}$ & & $\begin{array}{c}-0.037 \\
(0.041)\end{array}$ \\
\hline Withdraws Entire Salary on Payday $(=1)$ & & $\begin{array}{c}0.024 \\
(0.040)\end{array}$ & & $\begin{array}{c}0.026 \\
(0.040)\end{array}$ \\
\hline Capable of Fixing Phone $(=1)$ & & $\begin{array}{c}0.077 \\
(0.039)\end{array}$ & & $\begin{array}{l}0.056 \\
(0.039)\end{array}$ \\
\hline Constant & $\begin{array}{l}0.726 \\
(0.054)\end{array}$ & $\begin{array}{c}0.679 \\
(0.126)\end{array}$ & $\begin{array}{c}0.634 \\
(0.055)\end{array}$ & $\begin{array}{c}0.589 \\
(0.128)\end{array}$ \\
\hline Control Mean & 0.72 & 0.73 & 0.72 & 0.73 \\
\hline R-Squared & 0.009 & 0.032 & 0.004 & 0.026 \\
\hline \# Employees & 702 & 678 & 702 & 678 \\
\hline
\end{tabular}

Notes: This table reports on the variables that predict whether a participant remains at their default election on February 28,2015 , two months after the start of the experiment. $\beta$ is a measure of present bias obtained in an experimental elicitation completed at endline with real stakes (see paper text for details). Cognitive Reflection Test (0-3) is the total of three questions answered correctly using a variant of Frederick (2005)'s cognitive reflection test. The remaining variables are described in Appendix D.2. Robust standard errors reported in parentheses. 


\section{Table 6: Which Element of the Consultation is Associated with Switching?}

\begin{tabular}{|c|c|c|c|c|}
\hline \multirow[t]{2}{*}{ Dependent Variable: } & \multicolumn{4}{|c|}{$\begin{array}{l}\text { Changed Contribution } \\
\text { After February } 28(=1)\end{array}$} \\
\hline & $(1)$ & $(2)$ & $(3)$ & (4) \\
\hline Assigned Consultation $(=1)$ & $\begin{array}{c}0.091 \\
(0.018)\end{array}$ & & & \\
\hline Accepted Consultation $(=1)$ & & $\begin{array}{c}0.154 \\
(0.024)\end{array}$ & & \\
\hline Did Not Delay Consultation $(=1)$ & & & $\begin{array}{l}-0.083 \\
(0.270)\end{array}$ & $\begin{array}{l}-0.090 \\
(0.273)\end{array}$ \\
\hline Asked for Overview of M-Paz $(=1)$ & & & $\begin{array}{c}0.042 \\
(0.047)\end{array}$ & $\begin{array}{c}0.070 \\
(0.051)\end{array}$ \\
\hline Initial Questions about M-Paz (=1) & & & $\begin{array}{c}0.047 \\
(0.049)\end{array}$ & $\begin{array}{c}0.050 \\
(0.052)\end{array}$ \\
\hline Aware of M-Paz Plan and Rate $(=1)$ & & & $\begin{array}{l}-0.139 \\
(0.079)\end{array}$ & $\begin{array}{l}-0.171 \\
(0.088)\end{array}$ \\
\hline Asked to Repeat Projected Balance $(=1)$ & & & $\begin{array}{c}0.124 \\
(0.066)\end{array}$ & $\begin{array}{c}0.114 \\
(0.069)\end{array}$ \\
\hline Calculation Assistance $(=1)$ & & & $\begin{array}{c}0.377 \\
(0.058)\end{array}$ & $\begin{array}{c}0.387 \\
(0.058)\end{array}$ \\
\hline Additional Questions about M-Paz (=1) & & & $\begin{array}{c}0.043 \\
(0.058)\end{array}$ & $\begin{array}{c}0.034 \\
(0.064)\end{array}$ \\
\hline Control Mean & 0.06 & 0.10 & 0.15 & 0.16 \\
\hline Covariates & $\mathrm{NO}$ & $\mathrm{NO}$ & $\mathrm{NO}$ & YES \\
\hline R-squared & 0.027 & 0.040 & 0.312 & 0.332 \\
\hline \# Employees & 927 & 443 & 295 & 287 \\
\hline
\end{tabular}

Notes: This table reports which elements of the financial consultation predict whether an employee switches their contribution. 469 of the 928 employees still active in our study at the time of this intervention were assigned to be offered a consultation, establishing the sample for column (1). Of these, 443 employees answered the call making the initial offer, establishing the sample for column (2). Of these 443, 327 employees agreed to a full consultation. Accepted Consultation is a dummy variable equal to 1 for these employees. Of the 327 employees who accepted the consultation, 295 were reached by the second caller offering the consultation, forming the sample for column (3). Of the 295 employees who both accepted and who were reached for a consultation, all completed the consultation. 291 were able to talk immediately (Did Not Delay Consultation=1), while 4 could not and were reached later. 259 requested an overview of the M-Pasandaz product (Asked for Overview of M-Paz=1), while 36 did not. 91 employees had initial questions about the M-Pasandaz product (Initial Questions about M$\mathrm{Paz}=1$ ), while 204 did not. 285 confirmed that they were aware of their plan and contribution rate (Aware of M-Paz Plan and Rate=1), while 10 were not. All were informed of their projected balance after six months including any potential bonus payments, and 52 employees asked for this information to be repeated (Asked to Repeat Projected Balance=1), while 242 did not. All were offered assistance with calculating how much money they would earn in different contribution scenarios, 95 requested assistance (Calculation Assistance=1), while 200 did not. Requesting assistance was not required to change the level of contribution to M-Pasandaz during the consultation call. 53 employees had additional questions about the M-Pasandaz product (Additional Questions about M-Paz=1), while 242 did not. Sample size in column 1 includes full sample subject to attrition when consultation was offered, column 2 sample includes all employees assigned a consultation, column 3 sample includes all employees who accepted a consultation, and column 4 excludes employees missing covariates. The additional covariates are: cognitive reflection test, risk preference, salary, tenure at Roshan, gender, education level, uses a bank account, withdraws entire salary on payday, and capable of fixing a phone. Robust standard errors are reported in parentheses. 


\section{Table 7: Consultation Offer Results By Present Bias}

\begin{tabular}{|c|c|c|c|c|c|}
\hline & \multicolumn{5}{|c|}{ Accepted Consultation $(=1)$} \\
\hline & (1) & (2) & (3) & (4) & $(5)$ \\
\hline Consult Later & $\begin{array}{c}0.063 \\
(0.047)\end{array}$ & $\begin{array}{c}0.081 \\
(0.048)\end{array}$ & $\begin{array}{c}0.008 \\
(0.065)\end{array}$ & $\begin{array}{l}0.056 \\
(0.126)\end{array}$ & $\begin{array}{c}0.510 \\
(0.271)\end{array}$ \\
\hline Present Biased $(=1)$ & & & $\begin{array}{l}-0.038 \\
(0.071)\end{array}$ & $\begin{array}{l}-0.035 \\
(0.071)\end{array}$ & $\begin{array}{c}0.005 \\
(0.072)\end{array}$ \\
\hline Consult Later x Present Biased & & & $\begin{array}{c}0.177 \\
(0.093)\end{array}$ & $\begin{array}{c}0.168 \\
(0.093)\end{array}$ & $\begin{array}{c}0.119 \\
(0.094)\end{array}$ \\
\hline Impatient $(=1)$ & & & & $\begin{array}{l}0.018 \\
(0.098)\end{array}$ & $\begin{array}{c}0.048 \\
(0.098)\end{array}$ \\
\hline Consult Later x Cognitive Reflection Test & & & & & $\begin{array}{l}-0.054 \\
(0.068)\end{array}$ \\
\hline Consult Later x Risk Preference & & & & & $\begin{array}{l}-0.013 \\
(0.017)\end{array}$ \\
\hline Consult Later x Salary & & & & & $\begin{array}{l}-0.004 \\
(0.002)\end{array}$ \\
\hline Consult Later $\mathrm{x}$ Tenure at Roshan & & & & & $\begin{array}{c}0.003 \\
(0.017)\end{array}$ \\
\hline Consult Later x Male & & & & & $\begin{array}{l}-0.093 \\
(0.153)\end{array}$ \\
\hline Consult Later x Education Level & & & & & $\begin{array}{l}-0.015 \\
(0.038)\end{array}$ \\
\hline Consult Later x Uses a Bank Account & & & & & $\begin{array}{c}0.068 \\
(0.103)\end{array}$ \\
\hline Consult Later x Withdraws Entire Salary on Payday & & & & & $\begin{array}{l}-0.170 \\
(0.097)\end{array}$ \\
\hline Consult Later x Capable of Fixing Phone & & & & & $\begin{array}{l}-0.063 \\
(0.104)\end{array}$ \\
\hline Constant & $\begin{array}{c}0.727 \\
(0.034)\end{array}$ & $\begin{array}{c}0.769 \\
(0.116)\end{array}$ & $\begin{array}{c}0.801 \\
(0.122)\end{array}$ & $\begin{array}{l}0.787 \\
(0.157)\end{array}$ & $\begin{array}{c}0.555 \\
(0.209)\end{array}$ \\
\hline Control Mean & 0.77 & 0.77 & 0.77 & 0.77 & 0.77 \\
\hline Covariates & No & Yes & Yes & Yes & Yes \\
\hline \# Observations & 329 & 329 & 329 & 329 & 329 \\
\hline R-Squared & 0.005 & 0.039 & 0.052 & 0.052 & 0.091 \\
\hline
\end{tabular}

Notes: Accepted Consultation Offer $(=1)$ is a binary variable that equals one if the employee agreed to participation in a financial consultation regarding their participation in the M-Pasandaz program (see paper text for details). Consult Later $(=1)$ is a binary variable that equals zero if the employee was randomly assigned to receive a consultation on the same day as the consultation offer was made, and equals one if the consultation was assigned to take place one week later. Present Biased (=1) is a binary variable that equals one if an employee is identified as having $\beta<1$ in an experimental present bias elicitation completed at endline with real stakes and Impatient $(=1)$ is a binary variable that equals one if an employee is identified as having $\delta<1$ (see paper text for details). Columns (2), (4) and (5) include covariates for cognitive reflection task, risk preference, salary, tenure at Roshan, gender, education level, uses a bank account, withdraws entire salary on payday, and capable of fixing a phone - see Appendix D.2 for questions. Robust standard errors reported in parentheses. 


\section{References}

Abadie, Alberto and Sebastien Gay, "The Impact of Presumed Consent Legislation on Cadaveric Organ Donation: A Cross Country Study," Journal of Health Economics, 2006, 25, 599-620.

Aker, Jenny C and Joshua E Blumenstock, "The Economic Impacts of New Technologies in Africa," in "The Oxford Handbook of Africa and Economics: Policies and Practices" November 2014.

Aker, Jenny C., Rachid Boumnijel, Amanda McClelland, and Niall Tierney, "Payment Mechanisms and Antipoverty Programs: Evidence from a Mobile Money Cash Transfer Experiment in Niger," Economic Development and Cultural Change, August 2016, $65(1), 1-37$.

Anderson, Siwan and Jean-Marie Baland, "The Economics of Roscas and Intrahousehold Allocation," Quarterly Journal of Economics, 2002, 117 (3), 963-995.

Andreoni, James and Charles Sprenger, "Estimating Time Preferences with Convex Budgets," American Economic Review, 2012, 102 (7), 3333-3356.

_, Michael A. Kuhn, and Charles Sprenger, "Measuring Time Preferences: A Comparison of Experimental Methods," Journal of Economic Behavior 83 Organization, 2015, 116.

_, Michael Callen, Karrar Hussain, Muhammad Yasir Khan, and Charles Sprenger, "Using Preference Estimates to Customize Incentives: An Application to Polio Vaccination Drives in Pakistan," 2016.

Ashraf, N., D. Karlan, and W. Yin, "Tying Odysseus to the mast: Evidence from a commitment savings product in the Philippines," The Quarterly Journal of Economics, 2006, $121(2), 635-672$.

Ashraf, Nava, "Spousal Control and Intra-Household Decision Making: An Experimental Study in the Philippines," American Economic Review, 2009, 99 (4), 1245-1277.

Augenblick, Ned, Muriel Niederle, and Charles Sprenger, "Working Over Time: Dynamic Inconsistency in Real Effort Tasks," Quarterly Journal of Economics, 2015, 130 (3), 1067-1115.

Banerjee, Abhijit and Sendhil Mullainathan, "The Shape of Temptation: Implications for the Economic Lives of the Poor," 2010. 
_, Arun G. Chandrasekhar, Esther Duflo, and Matthew O. Jackson, "The Diffusion of Microfinance," Science, 2013, 341 (6144).

Becker, Gary S. and Kevin M. Murphy, "A Theory of Rational Addiction," Journal of Political Economy, 1988, 96 (4), 675-700.

Benjamin, Daniel J, "Does 401(k) eligibility increase saving?: Evidence from propensity score subclassification," Journal of Public Economics, May 2003, 87 (5-6), 1259-1290.

Bernheim, Douglas, Andrey Fradkin, and Igor Popov, "The Welfare Economics of Default Options in 401(k) Plans," American Economic Review, September 2015, 105 (9), $2798-2837$.

Beshears, John, James Choi, David Laibson, and Brigitte Madrian, "The limitations of defaults," Technical Report, National Bureau of Economic Research 2010.

_, James J. Choi, David Laibson, and Brigitte C. Madrian, "The importance of default options for retirement saving outcomes: Evidence from the United States," in "Social security policy in a changing environment," University of Chicago Press, 2009, pp. 167-195.

_ , _ , , and _ , "The Impact of Employer Matching on Savings Plan Participation under Automatic Enrollment," NBER, February 2010, pp. 311-327.

_ , _ , _, _, and Katherine L. Milkman, "The Effect of Providing Peer Information on Retirement Savings Decisions," The Journal of Finance, June 2015, 70 (3), 1161-1201.

_, James J. Choi, David Laibson, Brigitte C. Madrian, and William L. Skimmyhorn, "Borrowing to Save? The Impact of Automatic Enrollment on Debt," 2017.

Bidwell, Kelly, Katherine Casey, and Rachel Glennerster, "Debates: Voting and Expenditure Responses to Political Communication," Technical Report 2016.

Blumenstock, J.E., N. Eagle, and M. Fafchamps, "Airtime Transfers and Mobile Communications: Evidence in the Aftermath of Natural Disasters," Journal of Development Economics, May 2016, 120, 157-181.

Blumenstock, Joshua Evan, Michael Callen, Tarek Ghani, and Lucas Koepke, "Promises and Pitfalls of Mobile Money in Afghanistan: Evidence from a Randomized Control Trial," in "Proceedings of the Fifth ACM/IEEE International Conference on Information and Communication Technologies and Development" ICTD '15 ACM Singapore 2015. 
Breza, Emily, Leora Klapper, and Martin Kanz, "The Real Effects of Electronic Wage Payments: A Field Experiment with Salaried Factory Workers in Bangladesh," In Progress, 2017.

Bronchetti, Erin Todd, Thomas S Dee, David B Huffman, and Ellen Magenheim, "When a nudge isn't enough: defaults and saving among low-income tax filers," Working Paper 16887, National Bureau of Economic Research March 2011.

Brown, Jeffrey R. and Alessandro Previtero, "Procrastination, present-biased preferences, and financial behaviors," Technical Report, National Bureau of Economic Research 2014.

_, Anne M. Farrell, and Scott J. Weisbenner, "Decision-making approaches and the propensity to default: Evidence and implications," Journal of Financial Economics, September 2016, 121 (3), 477-495.

Bruhn, Miriam and David McKenzie, "In Pursuit of Balance: Randomization in Practice in Development Field Experiments," American Economic Journal: Applied Economics, 2009, 1 (4), 200-232.

Brune, Lasse, Xavier Giné, Jessica Goldberg, and Dean Yang, "Savings defaults and payment delays for cash transfers: Field experimental evidence from Malawi," Journal of Development Economics, November 2017, 129, 1-13.

Burgess, Robin and Rohini Pande, "Do Rural Banks Matter? Evidence from the Indian Social Banking Experiment," American Economic Review, 2005, 95 (3), 780-795.

Bursztyn, Leonardo, Florian Ederer, Bruno Ferman, and Noam Yuchtman, "Understanding Mechanisms Underlying Peer Effects: Evidence From a Field Experiment on Financial Decisions," Econometrica, July 2014, 82 (4), 1273-1301.

Callen, Michael, Suresh de Mel, Craig McIntosh, and Christopher Woodruff, "What Are the Headwaters of Formal Savings? Experimental Evidence from Sri Lanka," 2017.

Carroll, Gabriel D., James J. Choi, David Laibson, Brigitte C. Madrian, and Andrew Metrick, "Optimal Defaults and Active Decisions," The Quarterly Journal of Economics, November 2009, 124 (4), 1639-1674.

Carter, Michael R, Rachid Laajaj, and Dean Yang, "Raising Returns, Managing Risk: A Randomized Experiment on Combining Input Subsidies with Financial Services Interventions," mimeo UC Davis, 2015. 
Carvalho, Leandro S., Stephan Meier, and Stephanie W. Wang, "Poverty and Economic Decision-Making: Evidence from Changes in Financial Resources at Payday," Working Paper, 2014.

Casey, Katherine, Rachel Glennerster, and Edward Miguel, "Reshaping Institutions: Evidence on Aid Impacts Using a Pre-Analysis Plan," Quarterly Journal of Economics, 2012, 127 (4), 1755-1812.

Chabris, Christopher F., David Laibson, and Jonathon P. Schuldt, "Intertemporal Choice," in Steven N. Durlauf and Larry Blume, eds., The New Palgrave Dictionary of Economics, London: Palgrave Macmillan, 2008.

Chapman, Gretchen, Meng Li, and Helen Colby, "Opting in vs. Opting Out of Influenza Vaccination," Journal of the American Medical Association, 2010, 304 (1), 4344.

Charness, Gary and Uri Gneezy, "Incentives to Exercise," Econometrica, May 2009, 77 (3), 909-931.

Chetty, Raj, John N. Friedman, Søren Leth-Petersen, Torben Heien Nielsen, and Tore Olsen, "Active vs. Passive Decisions and Crowd-Out in Retirement Savings Accounts: Evidence from Denmark," The Quarterly Journal of Economics, August 2014, $129(3), 1141-1219$.

_, _, Soren Leth-Petersen, Torben Nielsen, and Tore Olsen, "Active vs. Passive Decisions and Crowdout in Retirement Savings Accounts: Evidence from Denmark," Working Paper 18565, National Bureau of Economic Research December 2013.

Chipchase, Jan, Mark Roston, Cara Silver, and Joshua Blumenstock, "In The Hands of God: A Study of Risk and Savings in Afghanistan," Technical Report 2013.

Choi, James J., David Laibson, Brigitte C. Madrian, and Andrew Metrick, "For better or for worse: Default effects and 401 (k) savings behavior," in "Perspectives on the Economics of Aging," University of Chicago Press, 2004, pp. 81-126.

Cole, Shawn, Thomas Sampson, and Bilal Zia, "Prices or Knowledge? What Drives Demand for Financial Services in Emerging Markets?," The Journal of Finance, December 2011, 66 (6), 1933-1967.

Cubitt, Robin P. and Daniel Read, "Can Intertemporal Choice Experiments Elicit Preferences for Consumption?," Experimental Economics, 2007, 10 (4), 369-389. 
DellaVigna, Stefano, "Psychology and Economics: Evidence from the Field," Journal of Economic Literature, June 2009, 47 (2), 315-372.

- and Ulrike Malmendier, "Paying Not to Go to the Gym," American Economic Review, June 2006, 96 (3), 694-719.

Demirguc-Kunt, Asli, Leora Klapper, Dorothe Singer, and Peter Van Oudheusden, "The Global Findex Database 2014: Measuring Financial Inclusion around the World," Technical Report, World Bank, Washington, DC 2015.

Dobrescu, LI, Xiaodong Fan, Hazel Bateman, BR Newell, Andreas Ortmann, and Susan Thorp, "Retirement Savings: A Tale of Decisions and Defaults," The Economic Journal, 2016.

Drexler, Alejandro, Greg Fischer, and Antoinette Schoar, "Keeping It Simple: Financial Literacy and Rules of Thumb," American Economic Journal: Applied Economics, April 2014, 6 (2), 1-31.

Duflo, Esther and Emmanuel Saez, "The Role of Information and Social Interactions in Retirement Plan Decisions: Evidence from a Randomized Experiment," The Quarterly Journal of Economics, August 2003, 118 (3), 815-842.

_, William Gale, Jeffrey Liebman, Peter Orszag, and Emmanuel Saez, "Saving Incentives for Low- and Middle-Income Families: Evidence from a Field Experiment with H\&R Block," The Quarterly Journal of Economics, November 2006, 121 (4), 1311-1346.

Dupas, Pascaline and Jonathan Robinson, "Why Don't the Poor Save More? Evidence from Health Savings Experiments," American Economic Review, 2013, 103 (4), 1138-71.

Engelhardt, Gary V. and Anil Kumar, "Employer matching and 401(k) saving: Evidence from the health and retirement study," Journal of Public Economics, November 2007, 91 (10), 1920-1943.

Frederick, Shane, "Cognitive reflection and decision making," The Journal of Economic Perspectives, 2005, 19 (4), 25-42.

Goda, Gopi Shah and Colleen Flaherty Manchester, "Incorporating employee heterogeneity into default rules for retirement plan selection," Journal of Human Resources, $2013,48(1), 198-235$. 
_, Matthew R. Levy, Colleen Flaherty Manchester, Aaron Sojourner, and Joshua Tasoff, "The Role of Time Preferences and Exponential-Growth Bias in Retirement Savings," Working Paper 21482, National Bureau of Economic Research August 2015.

GSMA, "State of the Industry Report on Mobile Money: Decade Edition," 2017 February 2017.

Hussam, Reshmaan, Atonu Rabbani, Giovanni Reggiani, and Natalia Rigol, "Habit Formation and Rational Addiction: A Field Experiment in Handwashing," 2017.

International Monetary Fund, "Financial Access Survey," 2015.

International Telecommunication Union, "World Telecommunication/ICT Development Report and database," 2015.

Jack, William and Tavneet Suri, "Risk Sharing and Transactions Costs: Evidence from Kenya's Mobile Money Revolution," American Economic Review, 2014, 104 (1), 183-223.

Johnson, Eric J. and Daniel Goldstein, "Do Defaults Save Lives?," Science, November 2003, 302 (5649), 1338-1339.

_, Steven Bellman, and Gerald L. Lohse, "Defaults, Framing and Privacy: Why Opting In-Opting Out1," Marketing Letters, February 2002, 13 (1), 5-15.

Kahneman, Daniel, Jack L. Knetsch, and Richard H. Thaler, "Anomalies: The Endowment Effect, Loss Aversion, and Status Quo Bias," Journal of Economic Perspectives, 1991, 5 (1), 193-206.

Kapsos, Steven and Evangelia Bourmpoula, "Employment and economic class in the developing world," ILO Research Paper 6, International Labor Organization 2013.

Karlan, Dean, Aishwarya Lakshmi Ratan, and Jonathan Zinman, "Savings by and for the Poor: A Research Review and Agenda," Review of Income and Wealth, 2014, 60 (1), 36-78.

_, Jake Kendall, Rebecca Mann, Rohini Pande, Tavneet Suri, and Jonathan Zinman, "Research and Impacts of Digital Financial Services," Working Paper 22633, National Bureau of Economic Research September 2016. DOI: 10.3386/w22633. 
_, Margaret McConnell, Sendhil Mullainathan, and Jonathan Zinman, "Getting to the Top of Mind: How Reminders Increase Saving," Management Science, 2016, 62 (12), 3393-3411.

Kast, Felipe, Stephan Meier, and Dina Pomeranz, "Saving More in Groups: Field Experimental Evidence from Chile," Technical Report 2016. DOI: 10.3386/w18417.

Köszegi, Botond and Matthew Rabin, "A Model of Reference-Dependent Preferences," The Quarterly Journal of Economics, November 2006, 121 (4), 1133-1165.

List, John A., Azeem M. Shaikh, and Yang Xu, "Multiple Hypothesis Testing in Experimental Economics," Technical Report 2016.

Luco, Fernando, "Switching costs and competition in retirement investment," Working Paper, Mimeo, Northwestern University 2013.

Lusardi, Annamaria and Olivia S. Mitchell, "Financial literacy and planning: Implications for retirement wellbeing," Technical Report, National Bureau of Economic Research 2011.

Madrian, Brigitte C., "Matching Contributions and Savings Outcomes: A Behavioral Economics Perspective," in "Matching Contributions for Pensions: A Review of International Experience," World Bank, 2013, pp. 289-310.

_ , "Applying Insights from Behavioral Economics to Policy Design," Annual Review of Economics, 2014, 6, 663-88.

- and Dennis F. Shea, "The Power of Suggestion: Inertia in 401(k) Participation and Savings Behavior," The Quarterly Journal of Economics, November 2001, 116 (4), 11491187.

Mani, Anandi, Sendhil Mullainathan, Eldar Shafir, and Jiaying Zhao, "Poverty Impedes Cognitive Function," Science, August 2013, 341 (6149), 976-980.

Mullainathan, Sendhil and Eldar Shafir, Scarcity: Why having too little means so much, Macmillan, 2013.

Muralidharan, Karthik, Paul Niehaus, and Sandip Sukhtankar, "Building State Capacity: Evidence from Biometric Smartcards in India," American Economic Review, October 2016, 106 (10), 2895-2929. 
O'Donoghue, Ted and Matthew Rabin, "Doing It Now or Later," American Economic Review, 1999, 89 (1), 103-124.

Romano, Joseph P., "Hypothesis Testing in Econometrics," Annual Revview of Economics, 2010, 2, 75-104.

Rosenzweig, Mark R, Kenneth I Wolpin et al., "Credit Market Constraints, Consumption Smoothing, and the Accumulation of Durable Production Assets in Low-Income Countries: Investment in Bullocks in India," Journal of Political Economy, 1993, 101 (2), $223-44$.

Samuelson, William and Richard Zeckhauser, "Status quo bias in decision making," Journal of Risk and Uncertainty, March 1988, 1 (1), 7-59.

Schaner, Simone, "Do Opposites Detract? Intrahousehold Preference Heterogeneity and Inefficient Strategic Savings," American Economic Journal: Applied Economics, 2015, 7 (2), 135-174.

_ , "The Persistent Power of Behavioral Change: Long-Run Impacts of Temporary Savings Subsidies for the Poor," Working Paper 22534, National Bureau of Economic Research August 2016. DOI: 10.3386/w22534.

Schilbach, Frank, "Alcohol and Self-Control: A Field Experiment in India," 2017.

Shah, Anuj, Sendhil Mullainathan, and Eldar Shafir, "Some Consequences of Having Too Little," Science, 2012, 338 (6107), 682-685.

Somville, Vincent and Lore Vandewalle, "Saving by Default: Evidence from a Field Experiment in Rural India," American Economic Journal: Applied Economics, 2017, forthcoming.

Suri, Tavneet and William Jack, "The long-run poverty and gender impacts of mobile money," Science, December 2016, 354 (6317), 1288-1292.

Taubinsky, Dmitry, "From intentions to actions: A model and experimental evidence of inattentive choice," Working Paper, 2013.

Thaler, Richard H., "Mental accounting matters," Journal of Behavioral Decision Making, September 1999, 12 (3), 183-206. 
Tversky, Amos and Daniel Kahneman, "Loss Aversion in Riskless Choice: A ReferenceDependent Model," The Quarterly Journal of Economics, November 1991, 106 (4), 10391061.

Zwane, Alix Peterson, Jonathan Zinman, Eric Van Dusen, William Pariente, Clair Null, Edward Miguel, Michael Kremer, Dean S. Karlan, Richard Hornbeck, Xavier Giné, and others, "Being surveyed can change later behavior and related parameter estimates," Proceedings of the National Academy of Sciences, 2011, 108 (5), $1821-1826$. 


\section{Appendices - For Online Publication}

\section{List of Appendices}

$\begin{array}{ll}\text { A Impacts on Total Savings } & 51\end{array}$

B Present Bias and the Default Effect $\quad 54$

C Additional Tests of Robustness $\quad 56$

C.1 Robustness of Main Effects . . . . . . . . . . . . . . . . . 56

C.2 Measurement Error in Survey Data . . . . . . . . . . . . . . . 56

$\begin{array}{lr}\text { D Experimental Scripts } & 84\end{array}$

D.1 Financial Consultation . . . . . . . . . . . . . . . . . . 84

D.2 Survey instrument (selected questions) $\ldots \ldots \ldots \ldots$

D.3 Present Bias Elicitation . . . . . . . . . . . . . . . . . . . . . . . 92

\section{List of Appendix Figures}

A1 Switching behavior over time . . . . . . . . . . . . . 57

A2 M-Pasandaz reminder message . . . . . . . . . . . . . . . 58

A3 Employee perceptions of M-Pasandaz . . . . . . . . . . . . . . . . . . 59

A4 Employee uses and plans for M-Pasandaz savings . . . . . . . . . . . 60

\section{List of Appendix Tables}

A1 Default Savings Effects in Related Literature . . . . . . . . . . . . . . . 61

A2 Summary Statistics . . . . . . . . . . . . . . . . . . . . . . . 62

A3 Self-reported Reasons for Switching Contribution Rates . . . . . . . . . . 63

A4 The Default Effect on Robustness to Withdrawing to Exit the Account . . . 64

A5 The Default Effect on Participation and Contribution (as of July 15) . . . 65

A6 The Default Effect: Heterogeneity by Salary Quartile . . . . . . . . . . 66

A7 The Default Effect on Household Savings . . . . . . . . . . . . . . . 67

A8 The Default Effect on Asset Ownership . . . . . . . . . . . . . . 68

A9 The Default Effect on Savings, by Matching Rate . . . . . . . . . . . . 69

A10 Long Term Effect of Defaults on M-Paz Balances by Quarter . . . . . . . 70 
A11 The Default Effect on Savings Behaviors and Attitudes, by Match Rate . . . 71

A12 Effect of Matching Incentives on Savings Behavior, Financial Security, and Well-Being . . . . . . . . . . . . . . . . . 72

A13 "Top of the Mind" Treatments . . . . . . . . . . . . . . . . . . . . 73

A14 Present Bias and Contribution Changes (Unincentivized Baseline Measure) . 74

A15 Present Bias and Contribution Changes - Heterogeneity by Default Assign-

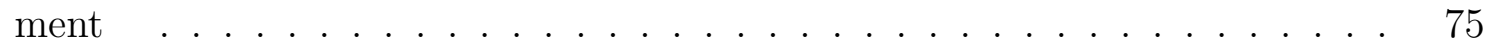

A16 The Default Effect: Additional Heterogeneity . . . . . . . . . . . . 76

A17 Which Element of the Consultation is Associated with Switching: Heterogeneity 77

A18 Consultation Offer and Present Bias (Unincentivized Baseline Measure) . 78

A19 Which Treatments Move Participants From Their Default Contribution? . . . . . 79

B1 The Default Effect on Total Contributions (incl. strata fixed effects) . . . . . 80

B2 The Default Effect on Active Decision at Trial End (incl. strata fixed effects) 81

B3 Which Element of the Consultation is Associated with Switching (incl. strata fixed effects)? . . . . . . . . . . . . . . . . . . . . . . 82

B4 Consultation Offer Results By Present Bias (incl. strata fixed effects) . . . . 83 


\section{A Impacts on Total Savings}

All employees participated in face-to-face baseline (January 2015) and endline (August 2015) surveys. Half of all employees were also randomly selected to participate in higher-frequency phone surveys, which occurred in March, May, June, and July of 2015. As we discuss in greater detail in Section 5.3, only half of all employees were selected for high-frequency surveys out of concern that being surveyed might, by itself, change savings behavior.

To study the effects of default assignment on total savings, we measure savings using monthly panel data, as described in the main manuscript. Our questions regard savings at the household level, since most participants are the primary breadwinner in their household. The monthly surveys captured flows in the five main financial household savings instruments relevant for our sample: (i) the M-Pasandaz wallet; (ii) the M-Paisa wallet; (iii) as cash; (iv) in a bank account; or (v) as loans given to family and friends. We also aggregate these five types of savings to look at a sixth savings measure: total financial savings. Given our sample of urban salaried employees, these measures provide a fairly comprehensive overview of potential savings. ${ }^{42}$ These survey data are likely reported with error, but the fact that we observe M-Pasandaz balances in both the survey and administrative data gives us some insight into potential misreporting. As we discuss in Appendix C.2, there is evidence of confusion by some employees on whether to report stocks (which can be read easily and precisely by looking at the M-Paisa interface) or flows; after correcting for this, we observe a correlation between the survey and administrative measures of $r=0.85$.

Appendix Table A7 examines the impact of defaults on different types of savings. Our base specification uses a difference-in-difference estimator by regressing monthly flows $\left(Y_{i t}\right)$ between individuals assigned a default contribution rate of $5 \%$ (Default $\operatorname{In}_{i}=1$ ) and $0 \%$ (Default $\left.\operatorname{In}_{i}=1\right)$ :

$$
Y_{i t}=\gamma_{1} \text { Default } \text { In }_{i} \cdot \text { Post }_{t}+\eta_{i}+\psi_{t}+\varepsilon_{i t}
$$

Here, Post $_{t}$ is an indicator equal to one in the post-treatment period (survey waves 2 - 5) and $\eta_{i}$ and $\psi_{t}$ are employee and survey wave fixed effects, respectively. We investigate whether

\footnotetext{
${ }^{42}$ While previous development studies have focused on non-financial savings behaviors (cf. Rosenzweig et al., 1993), including jewelry, livestock or durables, these appear to be less relevant in our population of urban wage-earners. At the baseline survey, only $2 \%$ of respondents reported non-traditional savings, and we do not find evidence of default effects on self-reported asset ownership in Appendix Table A8.
} 
the default effect varies depending on the assigned employer match rate by estimating:

$$
\begin{aligned}
Y_{i t}= & \beta_{1} 25 \% \text { Match } \cdot \text { Default Out } \\
& + \text { Post }_{t}+\beta_{2} 50 \% \text { Match } \cdot \text { Default Out } \\
& +\beta_{3} \text {. Post } \text { Po }_{t} \\
& +\beta_{5} 50 \% \text { Match } \cdot \text { Default In } n_{i} \cdot \text { Post }_{t}+\beta_{4} 25 \% \text { Match } \cdot \text { Default } \text { In }_{i} \cdot \text { Post }_{t} \\
&
\end{aligned}
$$

such that each $\beta$ coefficient provides the difference-in-difference estimate of the effect of treatment assignment relative to the omitted category $(0 \%$ employer match and defaulted out). In this latter specification, our power for pairwise tests of differences in means is somewhat limited by the fact that we are comparing 6 different treatment conditions across only 470 employees.

Estimates in Panel A indicate that default enrollment in M-Pasandaz causes a positive but statistically insignificant increase in total savings (Column 1). Across all savings instruments, the only significant effect is an increase in M-Pasandaz savings, which is evident in both the administrative (Column 2) and survey (Column 3) data. We also find positive effects of default enrollment on regular M-Paisa account flows using survey data (Column 4). The remaining columns report somewhat imprecisely measured effects of default assignment on alternative savings instruments (Columns 5-6), loans and transfers made (Column 7) and expenditures (Columns 8-9). ${ }^{43}$ While the estimates are imprecise, in the aggregate, they indicate that both M-Pasandaz and M-Paisa savings are going up, and that may reflect a reduction in cash savings and/or consumption expenditure.

The average default effect masks considerable heterogeneity. In particular, our sample has remarkable variation in salary levels, ranging from about $\$ 150$ USD a month (e.g., guards and janitors) to over $\$ 3,000$ USD a month (senior managers). Consistent with prior work showing that the default is most important for poorer individuals (Madrian and Shea, 2001; Choi et al., 2004; Beshears et al., 2010a), we find large and statistically significant increases in total savings for employees in the lowest salary quartile (Panel B of Appendix Table A7). In this quartile, the net increase in savings is driven by increases in M-Pasandaz and M-Paisa, and is partially offset by a reduction in cash savings. We interpret these results with some caution, however. First, while the 'sources and uses' add up sensibly for the aggregate sample, in the poorest quartile it appears that both savings and consumption are increasing. Logically, this is only possible if employees or their household members are taking on additional outside work, which we did not record as our sample is salaried (though janitors and guards in

\footnotetext{
${ }^{43}$ We might expect the increase in M-Pasandaz savings to crowd out other forms of borrowing (Beshears et al., 2010b). We observe no effect on borrowing, but this may be due to the fact that our population tended to be net lenders - less than $6 \%$ of our population (53/947) reported receiving loans or transfers at baseline, a number that did not change significantly over the course of our study.
} 
the sample certainly could be increasing household labor participation). ${ }^{44}$ We additionally examine whether the M-Pasandaz account assisted subjects in dealing with shocks, but find no empirical evidence that it did so over the 6 months of this study (results available on request).

In addition to the default effects discussed above, the financial incentives offered by MPasandaz led to sizable increases in total savings (see Appendix Table A9), which appear to come from reductions in general expenditures (though food expenditure, specifically, is unaffected). Employees in the 50\% match group, for example, save about 4,000 more AFs per month (about $\$ 60$ USD), independent of default status, than those defaulted out in the $0 \%$ match group. The median monthly salary in our sample is about $\$ 450$ USD, so the M-Pasandaz program increased monthly savings by about $13 \%$ of monthly wages.

Of related interest is how employees perceived these savings and the M-Pasandaz account more generally. M-Pasandaz is a new product, with some features of a mobile money wallet, and some features of a defined contribution savings account. Employees thought M-Pasandaz was most similar to a savings account at a bank (Appendix Figure A3), and generally viewed their accumulated savings as long-term savings. Indeed, of the 349 employees who made contributions to their M-Pasandaz account, only about half $(n=186)$ had made a withdrawal at the time of the endline survey, with the remainder opting to leave the accrued balance untouched. When asked about their plans for this money, the most common response (after "Don't know") was that employees planned to retain their M-Pasandaz balance as savings for the future (Appendix Figure A4).

\footnotetext{
${ }^{44}$ Callen et al. (2017) find that a new savings product increases labor market participation for microentrepreneurs in Sri Lanka. An additional concern with these types of outcomes is that, especially in richer populations, the underlying distributions are fat-tailed, which may mean that substantial samples are required for the sampling distribution of the regression estimates to converge to their limiting distribution. This is potentially less of a concern in the bottom quartile of this sample, where monthly flows are smaller.
} 


\section{B Present Bias and the Default Effect}

Following O'Donoghue and Rabin (1999), it is evident that when an action involves immediate costs and delayed benefits, then naïve present-biased individuals are likely to procrastinate. The decision of whether to undertake the costly action of enrolling in M-Pasandaz today, in order to received the delayed benefits of an employer match, reflect such a decision. This section presents a simple framework to situate this insight in our setting.

Consider an employee who is defaulted out of M-Pasandaz and in the $50 \%$ match group who faces an immediate cost of switching $\kappa$. The employee is deciding whether to enter the program. To simplify, imagine the employee is considering whether to make a $\$ 2$ monthly contribution and if the employee enters, then they will make no further switches. The program runs for six months $t \in\{1,2, \ldots, 6\}$, benefits are paid out in $t=7$ at the conclusion of the trial, and, without loss of generality, that the employee has a one period discount factor $\delta=1$. If the employee starts making contributions in period $t$, they will invest $\$ 2(7-t)$ of principal over the course of the trial and receive back $\$(7-t)$ in employer matches.

Following O'Donoghue and Rabin (1999), assume the employee has utility function:

$$
U^{t}(\tau)= \begin{cases}\beta v_{\tau}-c_{\tau} & \text { if } \tau=t \\ \beta v_{\tau}-\beta c_{\tau} & \text { if } \tau>t\end{cases}
$$

where $\tau$ is the period when the switch is made, $v_{\tau}$ is the reward (which is always delayed, even in the sixth month of the program), and $c_{\tau}$ is the cost. Individuals can either be exponential discounters $(\beta=1)$, present-biased sophisticates $(\beta<1)$ who have correct beliefs, denoted as $\hat{\beta}$ about their future preferences $(\hat{\beta}=\beta)$, or present-biased naifs, who incorrectly assume they will not be present-biased in the future $(\hat{\beta}=1)$. We assume that the payoff for never participating in M-Pasandaz is 0 .

The benefits to participation are therefore $v_{\tau}=3(7-\tau)$, as two dollars in principal plus one dollar in employer match is provided per period of participation, and the costs are $c_{\tau}=\kappa+2+\beta 2(6-\tau)$, reflecting the switching cost and the stream of payments into the account over the life of the trial.

An exponential discounter switches if $(9-\tau)>\kappa+2$. Because this is declining in $\tau$, a basic prediction is that if an exponential discounter is going to switch at all, they do so immediately. This embodies the simple intuition that if participation is worthwhile in one period, then, with no discounting, it is worthwhile in every period, so the employee should take advantage of the full potential employer match.

A present-biased sophisticate displays a similar pattern of equilibrium behavior. In any period, a present-biased sophisticate should switch if $\beta(9-\tau)>\kappa+2$. For a fixed $\kappa$, there 
exist degrees of present bias such that an exponential discounter will enroll and a presentbiased sophisticate will never enroll. Nonetheless, if it is ever worthwhile for a sophisticate to enroll, they should do so in the first period.

A present-biased naif, by contrast, could potentially never enroll, while always incorrectly believing that they will do so in the next period. Consider the simple example of $\beta=1 / 2$ and $\kappa=3$. Then, in period 1 , the employee will not enroll $8 \beta<\kappa+2 \Leftrightarrow 4<5$, as the present discounted benefits are less than the current cost of switching. However, in period 1, they incorrectly believe that they will invest in period 2 if $7>\kappa+2$, which, in this case holds. Yet, when period 2 arrives, they will not invest, as $7 \beta<\kappa+2$.

The essential insight here is that while a sophisticate correctly knows that his future self will only participate if $\beta(9-\tau)>\kappa+2$, a naif incorrectly believes their future self will participate if $9-\tau>\kappa+2$. That is, they think the constraint for their future selfs to participate is less onerous than it will in fact be when the future becomes the present.

An additional, albeit basic, insight that follows is that individuals who discount the future more heavily, regardless of whether they are present biased, are less likely to participate at all because participation involves immediate costs and delayed rewards. For this reason, we also include estimates of the one period discount factor in addition to a separate measure for present bias when trying to predict which of our subjects remain at the default. 


\section{Additional Tests of Robustness}

\section{C.1 Robustness of Main Effects}

Employees assigned a default contribution rate of $5 \%$ could also exit their account by making monthly withdrawals, rather than calling Human Resources and switching their contribution. In Appendix Table A4, we test robustness of the observed default effect when participation is redefined to mean both contributing some portion of salary to the program and never having made a withdrawal. Using this definition, defaulting employees in increases employee participation by 34 percentage points in the white and blue plans, and by 26 percentage points in the red plan, with all three differences being highly statistically significant. In Appendix Table A5, we show the main effects for particiption and contribution rate using the values of these variables at the end of the study on July 15th instead of February 28th, following the series of follow-up interventions. At this time, defaulting employees in increases participation by 33 percentage points, and contribution rates by 1.56 percentage points, with similar patterns by matching rates to Table 1 .

\section{C.2 Measurement Error in Survey Data}

To assess the quality of our panel survey data, we first examine whether survey data on MPasandaz balances, which is potentially subject to measurement error due to inaccurate recall or misreporting, corresponds to our administrative data which is measured without error. For the specific case of the M-Pasandaz balance, however, we can directly compare our survey measure of reported flows into the account with the administrative record. This comparison reveals two systematic problems with the survey measure. First, a subsample of employees appears to respond to the survey question, designed to measure monthly flows, by reporting their current stock. If we adjust the data by replacing the monthly survey flow as the difference between monthly survey responses, the correlation between the administrative and the survey measure rises from 0.51 to 0.71 . Second, all respondents appear to report negative flows as zero. The correlation between the adjusted survey measure and the administrative measure rises to 0.85 if we exclude individuals who report a monthly flow of zero from the data. Appendix Table A7 reports results using both the administrative data and the monthly survey data adjusting the survey response to a monthly flow using the difference between monthly survey responses for those who appear to be reporting their current stock. 
Figure A1: Switching behavior over time
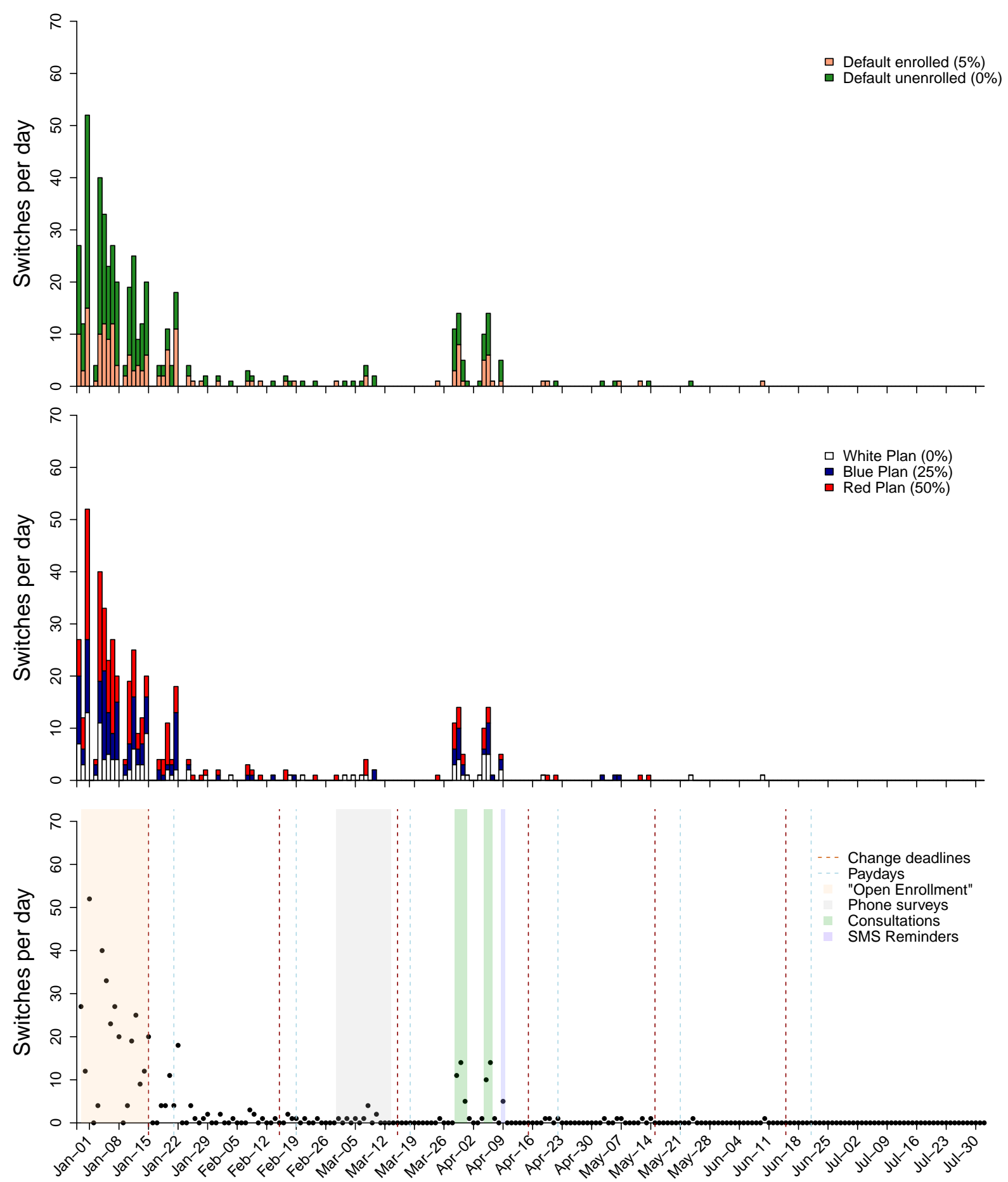

Notes: Dots indicate the number of individuals calling in, on a given day, to change their contribution rate. Top figure shows number of switches by default enrollment status; middle figure shows switches by plan assignment; bottom figure shows these switches in the context of the treatments that were administered to random subsets of the population over the course of the study. 
Figure A2: M-Pasandaz reminder message

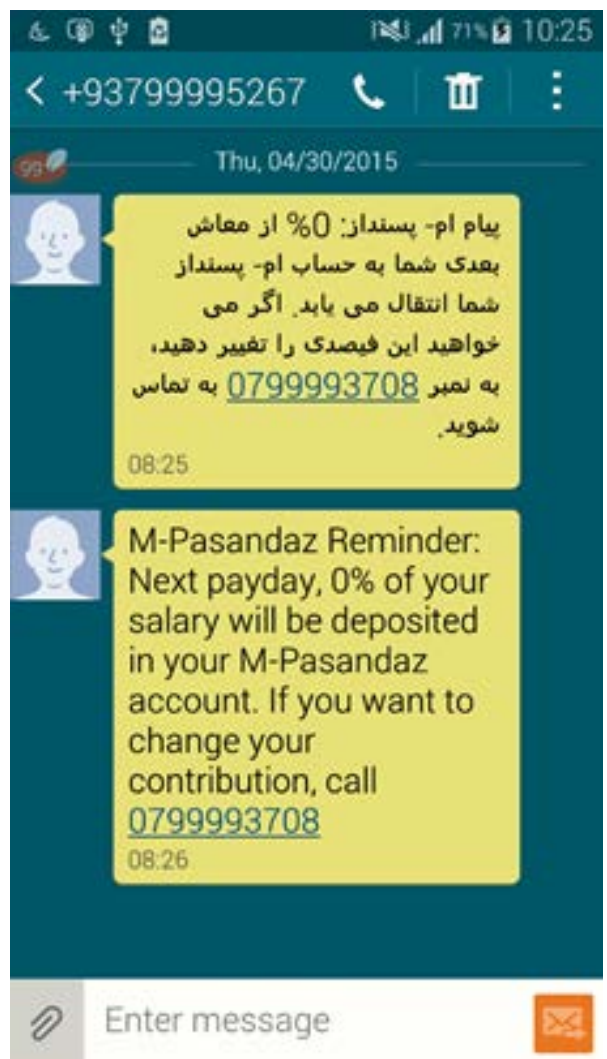


Figure A3: Employee perceptions of M-Pasandaz

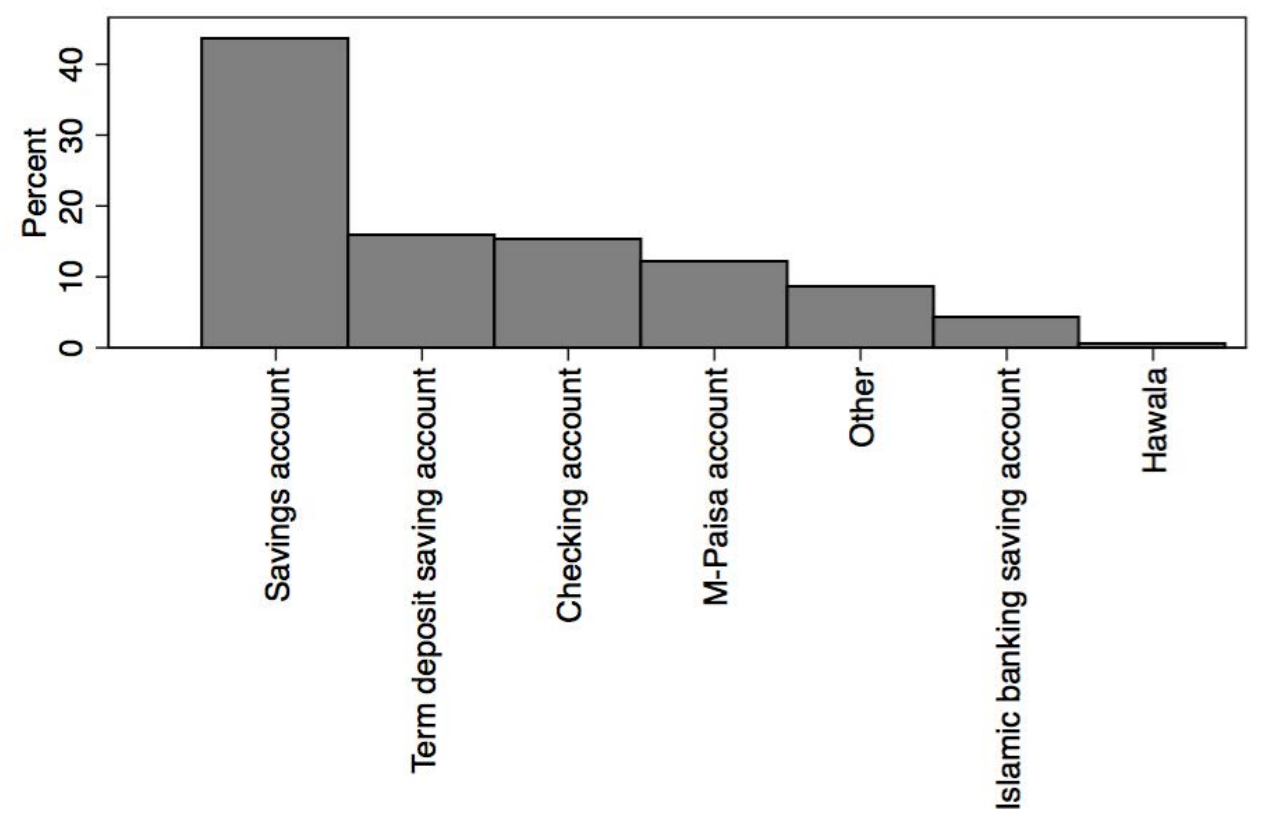

Which type of financial product do you think is most comparable to M-Pasandaz?

Notes: Responses collected in the endline survey, after the termination of the study period. Bars indicate the percent of employees who chose each option. Employees could only choose one option. 
Figure A4: Employee uses and plans for M-Pasandaz savings

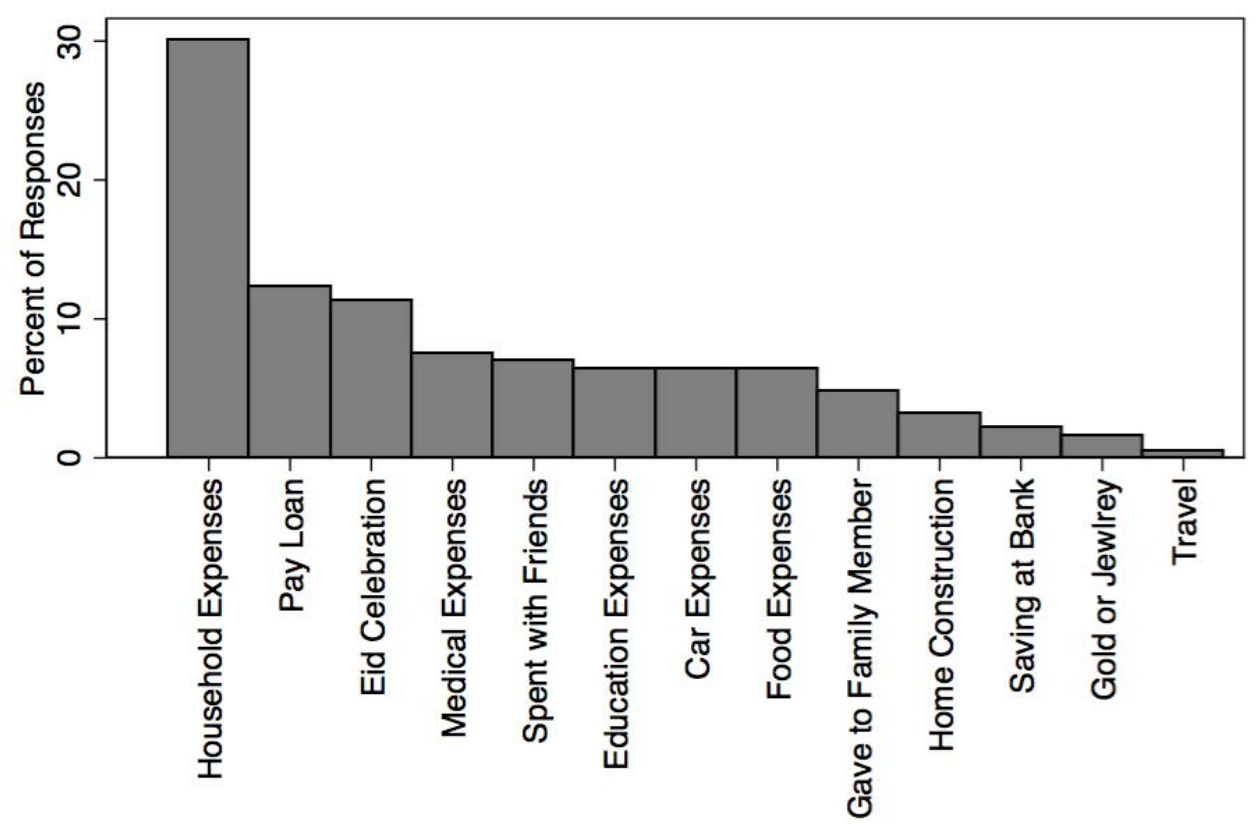

What did you spend the withdrawn (M-Pasandaz) money on?

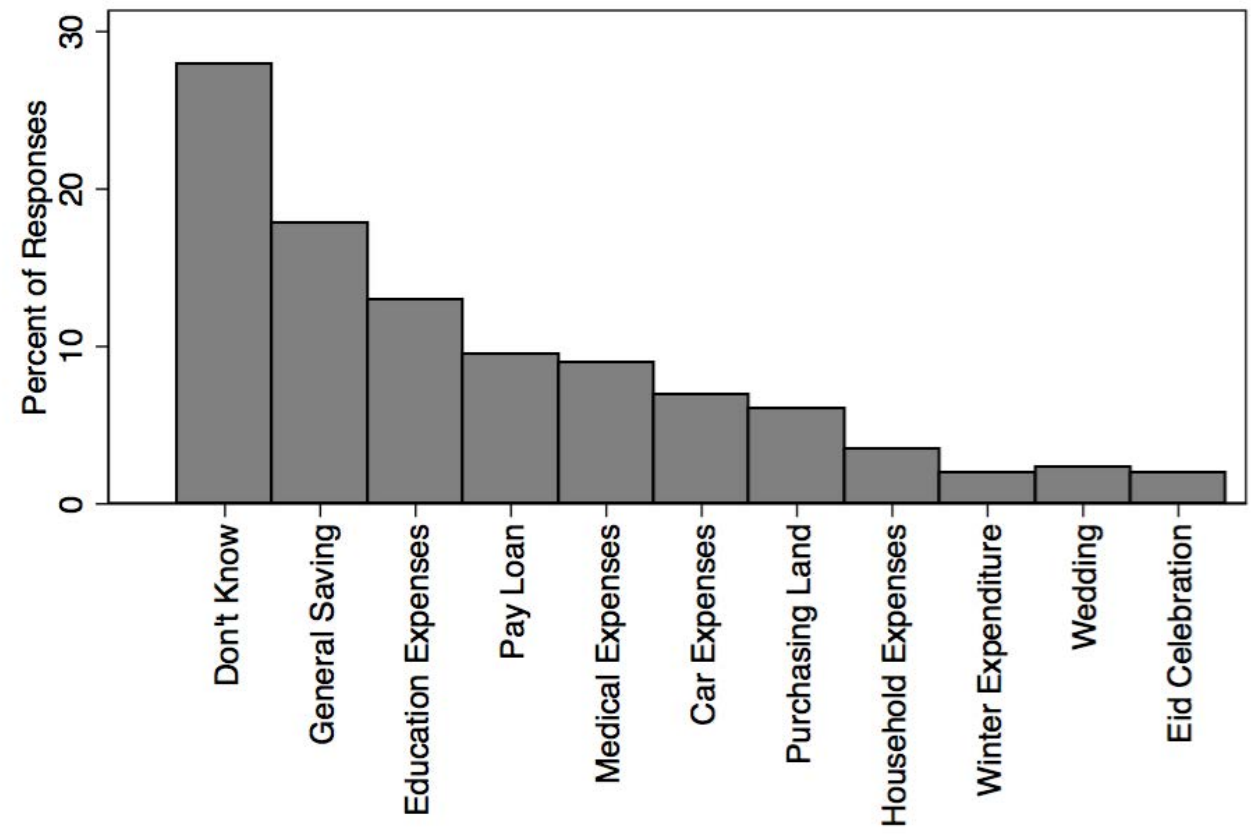

What do you plan on doing with the money in your M-Pasandaz account?

Notes: Responses collected in the endline survey, after the termination of the study period. Employees could give multiple responses to each question. Bars indicate the fraction of all employee responses that were affirmative for each expenditure category. 
Table A1: Default Savings Effects in Related Literature

\begin{tabular}{|c|c|c|}
\hline Reference & Study population & Default Effect Estimate \\
\hline $\begin{array}{l}\text { Bernheim et al. } \\
(2015)\end{array}$ & $\begin{array}{l}\text { Employees across three large } \\
\text { U.S. firms in chemicals, } \\
\text { insurance and food }\end{array}$ & $\begin{array}{l}\text { Estimating a model of costly opt-out in retirement savings } \\
\text { decisions, } 60 \% \text { of workers have positive opt-out costs, and } \\
40 \% \text { act as if opt-out costs are negligible (Table } 3 \text { ). }\end{array}$ \\
\hline $\begin{array}{l}\text { Beshears et al. } \\
(2009)\end{array}$ & $\begin{array}{l}\text { Subset of employees of a } \\
\text { U.S. office equipment firm }\end{array}$ & $\begin{array}{l}\text { When the default contribution rate is increased from } 3 \% \\
\text { to } 6 \% \text {, participation at the default increases from } 28 \% \text { to } \\
49 \% \text {. Participation at or above } 6 \% \text { increases from } 65 \% \text { to } \\
79 \% \text { (Figure } 5.3 \text { ). }\end{array}$ \\
\hline $\begin{array}{l}\text { Beshears et al. } \\
(2010 \mathrm{~b})\end{array}$ & $\begin{array}{l}645 \text { employees at a U.S. } \\
\text { information sector firm }\end{array}$ & $\begin{array}{l}89 \% \text { of employees participated when given a } 25 \% \text { match; } \\
80.7 \% \text { participated with no match. The average } \\
\text { contribution rate also fell from } 3.60 \text { percent to } 2.89 \\
\text { percent (Table } 11.2 \text { ). }\end{array}$ \\
\hline $\begin{array}{l}\text { Bronchetti et } \\
\text { al. (2011) }\end{array}$ & $\begin{array}{l}259 \text { eligible tax filers at } 8 \\
\text { IRS sponsored Volunteer } \\
\text { Income Tax Assistance } \\
\text { (VITA) sites in the U.S. }\end{array}$ & $\begin{array}{l}\text { The treatment raised savings bond participation by no } \\
\text { more than } 8 \text { percentage points (Table } 3 \text { ). }\end{array}$ \\
\hline $\begin{array}{l}\text { Brune et al. } \\
(2017)\end{array}$ & $\begin{array}{l}474 \text { households in } 10 \text { villages } \\
\text { in Malawi }\end{array}$ & $\begin{array}{l}\text { Net deposits are } 2.9 \text { times higher one week later for } \\
\text { treatment households who are given a direct transfer } \\
\text { compared to the control group who receives their transfer } \\
\text { in cash (Table } 4 \text { ). }\end{array}$ \\
\hline $\begin{array}{l}\text { Carroll et al. } \\
(2009)\end{array}$ & $\begin{array}{l}4,580 \text { of } 46,944 \text { employees at } \\
\text { a U.S. financial services firm }\end{array}$ & $\begin{array}{l}\text { Enrollment rates are } 29 \text { percentage points higher when } \\
\text { employees are forced to make an active enrollment } \\
\text { decision }(69 \%) \text { than under a standard enrollment process } \\
\text { with default non-enrollment ( } 41 \% \text { ) (Figure } 1) \text {. }\end{array}$ \\
\hline $\begin{array}{l}\text { Chetty et al. } \\
(2014)\end{array}$ & $\begin{array}{l}4 \text { million individuals with } \\
\text { savings accounts from the } \\
\text { population of Denmark }\end{array}$ & $\begin{array}{l}85 \% \text { of individual savers in Denmark can be described as } \\
\text { passive savers who do not respond to subsidies for } \\
\text { retirement accounts, but are instead influenced by the } \\
\text { automatic contributions made for them (Page 1143). }\end{array}$ \\
\hline $\begin{array}{l}\text { Dobrescu et al. } \\
(2016)\end{array}$ & $\begin{array}{l}16,988 \text { members of an } \\
\text { Australian pension plan }\end{array}$ & $\begin{array}{l}\text { Among highly educated permanent employees, there is a } \\
4.4 \% \text { decreased probability that a default member will opt } \\
\text { out of the voluntary contributions default (Table } 3 \text { ). }\end{array}$ \\
\hline Luco (2013) & $\begin{array}{l}8,888 \text { individuals enrolled in } \\
\text { the Chilean Pension System }\end{array}$ & $\begin{array}{l}55 \% \text { of people in the Chilean fixed pension system did not } \\
\text { switch from the default saving option, despite significant } \\
\text { changes in the economic environment over the period of } \\
\text { fourteen years (Figure } 4 \text { ). }\end{array}$ \\
\hline $\begin{array}{l}\text { Goda and } \\
\text { Manchester } \\
(2013)\end{array}$ & $\begin{array}{l}925 \text { existing union employees } \\
\text { at at U.S. non-profit firm }\end{array}$ & $\begin{array}{l}\text { When an age threshold determines enrollment in defined } \\
\text { benefit (DB) vs. defined contribution (DC), employees } \\
\text { defaulted into DC are } 60 \text { percentage points more likely to } \\
\text { enroll in DC plan than those defaulted into DB (Figure } 1 \text { ). }\end{array}$ \\
\hline $\begin{array}{l}\text { Madrian and } \\
\text { Shea (2001) }\end{array}$ & $\begin{array}{l}\text { 13,355 employees from a U.S } \\
\text { health care insurance firm }\end{array}$ & $\begin{array}{l}61 \text { percent of employees hired under automatic enrollment } \\
\text { do nothing to move away from the employer-set default } \\
\text { rate for their } 401(\mathrm{k}) \text { plan (Table } 8) \text {. }\end{array}$ \\
\hline $\begin{array}{l}\text { Somville and } \\
\text { Vandewalle } \\
(2017)\end{array}$ & $\begin{array}{l}442 \text { villagers in } 18 \text { villages in } \\
\text { rural India }\end{array}$ & $\begin{array}{l}\text { Being paid in bank account instead of cash increases the } \\
\text { account balance by } 420 \text { Rupees ( } 110 \text { percent) after three } \\
\text { months of weekly payments. Villagers paid in cash do not } \\
\text { save more in other assets and rather increase expenditures } \\
\text { on regular consumption by } 402 \text { Rupees (Table } 4) \text {. }\end{array}$ \\
\hline
\end{tabular}


Table A2: Summary Statistics

\begin{tabular}{|c|c|c|c|c|c|c|c|c|}
\hline & & \multicolumn{3}{|c|}{ Default Out } & \multicolumn{3}{|c|}{ Default In } & \multirow[b]{2}{*}{$\begin{array}{l}\text { P-Value } \\
\text { of F-Test }\end{array}$} \\
\hline & All & $\begin{array}{l}0 \% \\
\text { Match }\end{array}$ & $\begin{array}{l}25 \% \\
\text { Match }\end{array}$ & $\begin{array}{l}50 \% \\
\text { Match }\end{array}$ & $\begin{array}{l}0 \% \\
\text { Match }\end{array}$ & $\begin{array}{l}25 \% \\
\text { Match }\end{array}$ & $\begin{array}{l}50 \% \\
\text { Match }\end{array}$ & \\
\hline Gender $($ Male = 1) & $\begin{array}{l}0.85 \\
(0.36)\end{array}$ & $\begin{array}{l}0.85 \\
(0.36)\end{array}$ & $\begin{array}{l}0.87 \\
(0.33)\end{array}$ & $\begin{array}{l}0.85 \\
(0.36)\end{array}$ & $\begin{array}{l}0.84 \\
(0.37)\end{array}$ & $\begin{array}{l}0.81 \\
(0.39)\end{array}$ & $\begin{array}{l}0.88 \\
(0.33)\end{array}$ & 0.59 \\
\hline Married $(=1)$ & $\begin{array}{l}0.64 \\
(0.48)\end{array}$ & $\begin{array}{l}0.66 \\
(0.47)\end{array}$ & $\begin{array}{l}0.64 \\
(0.48)\end{array}$ & $\begin{array}{l}0.62 \\
(0.49)\end{array}$ & $\begin{array}{l}0.66 \\
(0.48)\end{array}$ & $\begin{array}{l}0.64 \\
(0.48)\end{array}$ & $\begin{array}{l}0.65 \\
(0.48)\end{array}$ & 0.98 \\
\hline Age (Years) & $\begin{array}{l}30.39 \\
(7.88)\end{array}$ & $\begin{array}{l}30.30 \\
(7.51)\end{array}$ & $\begin{array}{l}30.13 \\
(7.33)\end{array}$ & $\begin{array}{l}30.58 \\
(8.34)\end{array}$ & $\begin{array}{l}30.51 \\
(8.14)\end{array}$ & $\begin{array}{l}29.98 \\
(7.63)\end{array}$ & $\begin{array}{l}30.87 \\
(8.38)\end{array}$ & 0.94 \\
\hline Cognitive Reflection Task & $\begin{array}{l}0.60 \\
(0.82)\end{array}$ & $\begin{array}{l}0.60 \\
(0.81)\end{array}$ & $\begin{array}{l}0.52 \\
(0.77)\end{array}$ & $\begin{array}{l}0.60 \\
(0.80)\end{array}$ & $\begin{array}{l}0.61 \\
(0.85)\end{array}$ & $\begin{array}{l}0.61 \\
(0.86)\end{array}$ & $\begin{array}{l}0.67 \\
(0.80)\end{array}$ & 0.70 \\
\hline Risk Preference (1-10) & $\begin{array}{l}4.93 \\
(3.05)\end{array}$ & $\begin{array}{l}5.06 \\
(3.17)\end{array}$ & $\begin{array}{l}4.74 \\
(3.18)\end{array}$ & $\begin{array}{l}5.11 \\
(2.96)\end{array}$ & $\begin{array}{l}5.22 \\
(3.04)\end{array}$ & $\begin{array}{l}4.59 \\
(3.02)\end{array}$ & $\begin{array}{l}4.88 \\
(2.92)\end{array}$ & 0.43 \\
\hline Monthly Salary (1000 Afs) & $\begin{array}{l}32.43 \\
(30.79)\end{array}$ & $\begin{array}{l}30.41 \\
(25.01)\end{array}$ & $\begin{array}{l}31.20 \\
(24.12)\end{array}$ & $\begin{array}{l}33.86 \\
(38.68)\end{array}$ & $\begin{array}{l}34.39 \\
(34.84)\end{array}$ & $\begin{array}{l}31.72 \\
(26.25)\end{array}$ & $\begin{array}{l}33.04 \\
(33.27)\end{array}$ & 0.84 \\
\hline Monthly Savings (1000 Afs) & $\begin{array}{l}15.73 \\
(57.96)\end{array}$ & $\begin{array}{l}12.20 \\
(27.70)\end{array}$ & $\begin{array}{l}28.26 \\
(119.05)\end{array}$ & $\begin{array}{l}11.78 \\
(25.90)\end{array}$ & $\begin{array}{l}16.49 \\
(35.77)\end{array}$ & $\begin{array}{l}10.77 \\
(21.11)\end{array}$ & $\begin{array}{l}14.97 \\
(52.61)\end{array}$ & 0.28 \\
\hline Tenure At Roshan (Years) & $\begin{array}{l}5.83 \\
(3.14)\end{array}$ & $\begin{array}{l}5.73 \\
(3.12)\end{array}$ & $\begin{array}{l}6.02 \\
(3.15)\end{array}$ & $\begin{array}{l}5.76 \\
(3.35)\end{array}$ & $\begin{array}{l}6.02 \\
(3.08)\end{array}$ & $\begin{array}{l}5.47 \\
(3.08)\end{array}$ & $\begin{array}{l}6.01 \\
(3.04)\end{array}$ & 0.53 \\
\hline Education Level (1-6) & $\begin{array}{l}4.79 \\
(1.23)\end{array}$ & $\begin{array}{l}4.80 \\
(1.19)\end{array}$ & $\begin{array}{l}4.74 \\
(1.30)\end{array}$ & $\begin{array}{l}4.73 \\
(1.24)\end{array}$ & $\begin{array}{l}4.87 \\
(1.10)\end{array}$ & $\begin{array}{l}4.86 \\
(1.23)\end{array}$ & $\begin{array}{l}4.76 \\
(1.30)\end{array}$ & 0.84 \\
\hline Has Bank Account (=1) & $\begin{array}{l}0.41 \\
(0.49)\end{array}$ & $\begin{array}{l}0.42 \\
(0.49)\end{array}$ & $\begin{array}{l}0.39 \\
(0.49)\end{array}$ & $\begin{array}{l}0.38 \\
(0.49)\end{array}$ & $\begin{array}{l}0.41 \\
(0.49)\end{array}$ & $\begin{array}{l}0.44 \\
(0.50)\end{array}$ & $\begin{array}{l}0.40 \\
(0.49)\end{array}$ & 0.88 \\
\hline Delayed a Bill Payment $(=1)$ & $\begin{array}{l}0.41 \\
(0.49)\end{array}$ & $\begin{array}{l}0.43 \\
(0.50)\end{array}$ & $\begin{array}{l}0.36 \\
(0.48)\end{array}$ & $\begin{array}{l}0.47 \\
(0.50)\end{array}$ & $\begin{array}{l}0.41 \\
(0.49)\end{array}$ & $\begin{array}{l}0.37 \\
(0.48)\end{array}$ & $\begin{array}{l}0.42 \\
(0.50)\end{array}$ & 0.40 \\
\hline Withdraws Entire Salary $(=1)$ & $\begin{array}{l}0.41 \\
(0.49)\end{array}$ & $\begin{array}{l}0.37 \\
(0.48)\end{array}$ & $\begin{array}{l}0.42 \\
(0.49)\end{array}$ & $\begin{array}{l}0.42 \\
(0.50)\end{array}$ & $\begin{array}{l}0.41 \\
(0.49)\end{array}$ & $\begin{array}{l}0.44 \\
(0.50)\end{array}$ & $\begin{array}{l}0.40 \\
(0.49)\end{array}$ & 0.82 \\
\hline Capable of Fixing Phone $(=1)$ & $\begin{array}{l}0.47 \\
(0.50)\end{array}$ & $\begin{array}{l}0.50 \\
(0.50)\end{array}$ & $\begin{array}{l}0.49 \\
(0.50)\end{array}$ & $\begin{array}{l}0.45 \\
(0.50)\end{array}$ & $\begin{array}{l}0.46 \\
(0.50)\end{array}$ & $\begin{array}{l}0.42 \\
(0.49)\end{array}$ & $\begin{array}{l}0.48 \\
(0.50)\end{array}$ & 0.71 \\
\hline Interested in M-Pasandaz (=1) & $\begin{array}{l}0.85 \\
(0.35)\end{array}$ & $\begin{array}{l}0.85 \\
(0.36)\end{array}$ & $\begin{array}{l}0.87 \\
(0.33)\end{array}$ & $\begin{array}{l}0.84 \\
(0.37)\end{array}$ & $\begin{array}{l}0.83 \\
(0.38)\end{array}$ & $\begin{array}{l}0.89 \\
(0.31)\end{array}$ & $\begin{array}{l}0.84 \\
(0.37)\end{array}$ & 0.63 \\
\hline Present Biased Baseline $(=1)$ & $\begin{array}{l}0.32 \\
(0.47)\end{array}$ & $\begin{array}{l}0.25 \\
(0.43)\end{array}$ & $\begin{array}{l}0.36 \\
(0.48)\end{array}$ & $\begin{array}{l}0.31 \\
(0.46)\end{array}$ & $\begin{array}{l}0.35 \\
(0.48)\end{array}$ & $\begin{array}{l}0.30 \\
(0.46)\end{array}$ & $\begin{array}{l}0.33 \\
(0.47)\end{array}$ & 0.30 \\
\hline Present Biased Endline $(=1)$ & $\begin{array}{l}0.41 \\
(0.49)\end{array}$ & $\begin{array}{l}0.44 \\
(0.50)\end{array}$ & $\begin{array}{l}0.43 \\
(0.50)\end{array}$ & $\begin{array}{l}0.34 \\
(0.48)\end{array}$ & $\begin{array}{l}0.41 \\
(0.49)\end{array}$ & $\begin{array}{l}0.42 \\
(0.49)\end{array}$ & $\begin{array}{l}0.44 \\
(0.50)\end{array}$ & 0.61 \\
\hline Observations & 949 & 161 & 158 & 159 & 158 & 158 & 155 & \\
\hline
\end{tabular}

Notes: Standard deviations reported in parentheses. See Appendix D.2 for covariate questions. Present Biased Baseline $(=1)$ is a binary variable that equals one if an employee is identified as having $\beta<1$ in an unincentivized present bias elicitation completed at baseline, and Present Biased Endline $(=1)$ is a binary variable that equals one if an employee is identified as having $\beta<1$ in an experimental present bias elicitation completed at endline with real stakes (see paper text for details). 
Table A3: Self-reported Reasons for Switching Contribution Rates

\begin{tabular}{|c|c|c|c|c|c|c|c|c|c|}
\hline & \multirow[b]{2}{*}{$N$} & \multirow[b]{2}{*}{ Total } & \multirow[b]{2}{*}{$\%$} & \multicolumn{3}{|c|}{ Default Out } & \multicolumn{3}{|c|}{ Default In } \\
\hline & & & & $0 \%$ & $25 \%$ & $50 \%$ & $0 \%$ & $25 \%$ & $50 \%$ \\
\hline \multicolumn{10}{|c|}{ Panel A: Reasons for increasing contribution rate } \\
\hline Increased - Savings Important & 189 & 285 & 66.32 & 7 & 32 & 59 & 9 & 36 & 46 \\
\hline Increased - Wanted Incentives & 107 & 285 & 37.54 & 0 & 15 & 46 & 0 & 18 & 28 \\
\hline Increased - Support Roshan & 10 & 285 & 3.51 & 1 & 1 & 1 & 1 & 3 & 3 \\
\hline Increased - Demand Commitment & 8 & 285 & 2.81 & 0 & 3 & 3 & 0 & 2 & 0 \\
\hline Increased - Thought Automatic & 5 & 285 & 1.75 & 0 & 3 & 2 & 0 & 0 & 0 \\
\hline \multicolumn{10}{|c|}{ Panel B: Reasons for decreasing contribution rate } \\
\hline Decreased - Salary Too Low & 52 & 170 & 30.59 & 0 & 0 & 0 & 22 & 17 & 13 \\
\hline Decreased - Incentives Too Low & 49 & 170 & 28.82 & 0 & 0 & 0 & 48 & 0 & 1 \\
\hline Decreased - Expenses Too High & 35 & 170 & 20.59 & 0 & 0 & 0 & 10 & 19 & 6 \\
\hline Decreased - Un-Islamic Product & 24 & 170 & 14.12 & 0 & 0 & 0 & 5 & 10 & 9 \\
\hline Decreased - Better Options & 4 & 170 & 2.35 & 0 & 0 & 0 & 3 & 1 & 0 \\
\hline \multicolumn{10}{|c|}{$\begin{array}{l}\text { Notes: Total in column } 2 \text { reports number of participants that either decreased their contribution rate (rows 1-5) or } \\
\text { increased their contribution rate (rows 6-10). Reasons were not mutually exclusive and respondents were asked to } \\
\text { report all relevant reasons for changing their contribution. "Decreased - Salary Too Low" indicates that respondents } \\
\text { felt their salary was not sufficiently large to allow for savings. "Decreased - Incentives Too Low" indicates that } \\
\text { respondents felt the incentives were not sufficiently high for savings. "Decreased - Expenses Too High" indicates } \\
\text { that respondents felt their other expenses were too high for savings. "Decreased - Un-Islamic Product" indicates } \\
\text { that respondents felt the M-Pasandaz product did not conform with Islamic practices. "Decreased - Better Op- } \\
\text { tions" indicates that respondents reported having better alternative savings options available. "Increased - Savings } \\
\text { Important" indicates that respondents said savings was an important goal for them. "Increased - Wanted Incen- } \\
\text { tives" indicates that respondents mentioned the incentives as important to their decision. "Increased - Support } \\
\text { Roshan" indicates that respondents mentioned wanting to support Roshan's development of a new product. "In- } \\
\text { creased - Demand Commitment" indicates that respondents mentioned needing commitment devices to help save. } \\
\text { "Increased - Thought Automatic" indicates that respondents mentioned thinking they were automatically enrolled } \\
\text { in the program when they were not. }\end{array}$} \\
\hline
\end{tabular}


Table A4: The Default Effect on Robustness to Withdrawing to Exit the Account

\begin{tabular}{lcccc}
\hline Dependent Variable: & \multicolumn{4}{c}{ Participates and No Withdrawal $(=1)$} \\
\cline { 2 - 5 } & $(1)$ & $(2)$ & $(3)$ & $(4)$ \\
\hline Default In (=1) & 0.33 & 0.33 & 0.25 & 0.31 \\
& $(0.04)$ & $(0.05)$ & $(0.05)$ & $(0.03)$ \\
Constant & 0.01 & 0.26 & 0.55 & 0.27 \\
& $(0.01)$ & $(0.04)$ & $(0.04)$ & $(0.02)$ \\
Sample & $0 \%$ Match & $25 \%$ Match & $50 \%$ Match & Full Sample \\
\# Observations & 316 & 313 & 309 & 938 \\
R-Squared & 0.194 & 0.111 & 0.073 & 0.096 \\
\hline
\end{tabular}

Notes: Participates and No Withdrawal $(=1)$ is a binary variable that equals one if the contribution rate is greater than zero and the employee never withdrew from their account. The dependent variable reflect employees' status as of February 28, 2015, following the first two paydays but prior to the rollout of phone surveys or secondary interventions. Robust standard errors reported in parentheses. 
Table A5: The Default Effect on Participation and Contribution (as of July 15)

\begin{tabular}{lcccc}
\hline Panel A: The effect on participation \\
Dependent Variable: & \multicolumn{4}{c}{ Participates $(=1)$} \\
\cline { 2 - 5 } & $(1)$ & $(2)$ & $(3)$ & $(4)$ \\
Default In (=1) & 0.33 & 0.36 & 0.38 & 0.23 \\
& $(0.03)$ & $(0.05)$ & $(0.05)$ & $(0.05)$ \\
Constant & 0.32 & 0.07 & 0.32 & 0.60 \\
& $(0.02)$ & $(0.02)$ & $(0.04)$ & $(0.04)$ \\
\hline \multirow{2}{*}{ Sample } & Complete & $0 \%$ Match & $25 \%$ Match & $50 \%$ Match \\
\# Observations & 890 & 298 & 299 & 293 \\
R-Squared & 0.108 & 0.174 & 0.148 & 0.064 \\
\hline \multirow{2}{*}{ Panel B: The effect on contribution rate } & & \\
Dependent Variable: & \multicolumn{4}{c}{ Contribution Rate $(\%$ of Salary $)$} \\
\cline { 2 - 5 } & $(5)$ & $(6)$ & $(7)$ & $(8)$ \\
Default In (=1) & 1.56 & 1.89 & 2.20 & 0.42 \\
& $(0.29)$ & $(0.29)$ & $(0.50)$ & $(0.50)$ \\
Constant & 3.11 & 0.46 & 3.07 & 5.92 \\
& $(0.22)$ & $(0.16)$ & $(0.38)$ & $(0.40)$ \\
\hline Sample & Complete & $0 \%$ Match & $25 \%$ Match & $50 \%$ Match \\
\# Observations & 890 & 298 & 299 & 293 \\
R-Squared & 0.032 & 0.125 & 0.062 & 0.002 \\
\hline
\end{tabular}

Notes: Participates $(=1)$ is a binary variable that equals one if the contribution rate is greater than zero, Contribution (\% of Salary) is the monthy contribution rate into MPasandaz as a percent of total salary, and an observation is an employee. Variables reflect contribution rate values observed as of July 15, 2015, just prior to the disbursement of matching incentives. Robust standard errors reported in parentheses. 
Table A6: The Default Effect: Heterogeneity by Salary Quartile

\begin{tabular}{|c|c|c|c|c|}
\hline & $(1)$ & $(2)$ & $(3)$ & $(4)$ \\
\hline \multicolumn{5}{|c|}{ Panel $A$. Dependent Variable $=$ Participates (non-zero contribution rate) } \\
\hline \multirow[t]{2}{*}{ Default In $(=1)$} & 0.45 & 0.37 & 0.42 & 0.37 \\
\hline & $(0.06)$ & $(0.06)$ & $(0.06)$ & $(0.06)$ \\
\hline \multirow[t]{2}{*}{ Constant } & 0.24 & 0.32 & 0.28 & 0.28 \\
\hline & $(0.04)$ & $(0.04)$ & $(0.04)$ & $(0.04)$ \\
\hline \multirow{3}{*}{$\begin{array}{l}\text { Salary Quartile Sample } \\
\text { \# Observations } \\
\text { R-Squared }\end{array}$} & $1 \mathrm{st}$ & 2nd & $3 \mathrm{rd}$ & 4 th \\
\hline & 239 & 227 & 236 & 234 \\
\hline & 0.200 & 0.134 & 0.173 & 0.141 \\
\hline \multicolumn{5}{|c|}{ Panel B. Dependent Variable = Contribution Rate ( $\%$ of Salary) } \\
\hline \multirow[t]{2}{*}{ Default In $(=1)$} & 1.69 & 1.59 & 2.16 & 1.61 \\
\hline & $(0.48)$ & $(0.54)$ & $(0.53)$ & $(0.54)$ \\
\hline \multirow[t]{2}{*}{ Constant } & 2.34 & 3.00 & 2.63 & 2.83 \\
\hline & $(0.38)$ & $(0.41)$ & $(0.41)$ & $(0.41)$ \\
\hline \multirow{3}{*}{$\begin{array}{l}\text { Salary Quartile Sample } \\
\text { \# Observations } \\
\text { R-Squared }\end{array}$} & $1 \mathrm{st}$ & 2nd & $3 r d$ & 4 th \\
\hline & 239 & 227 & 236 & 234 \\
\hline & 0.049 & 0.036 & 0.066 & 0.036 \\
\hline \multicolumn{5}{|c|}{ Panel C. Dependent Variable = Total M-Pasandaz Contributions (Afs) } \\
\hline \multirow[t]{2}{*}{ Default In $(=1)$} & 734.38 & 260.73 & 2871.54 & 5995.37 \\
\hline & $(362.10)$ & $(602.29)$ & $(934.56)$ & $(2546.34)$ \\
\hline \multirow[t]{2}{*}{ Constant } & 1501.72 & 3291.68 & 4138.81 & 9939.97 \\
\hline & $(263.60)$ & $(439.28)$ & $(656.27)$ & $(1546.56)$ \\
\hline \multirow{3}{*}{$\begin{array}{l}\text { Salary Quartile Sample } \\
\text { \# Observations } \\
\text { R-Squared }\end{array}$} & $1 \mathrm{st}$ & 2nd & $3 \mathrm{rd}$ & 4 th \\
\hline & 244 & 231 & 237 & 237 \\
\hline & 0.017 & 0.001 & 0.038 & 0.023 \\
\hline
\end{tabular}

Notes: Dependent variable in top panel, Participates $(=1)$, is a binary variable that equals one if the contribution rate is greater than zero, and dependent variable in middle panel, Contribution Rate (\% of Salary), is the monthy contribution rate into M-Pasandaz as a percent of total salary. Participates and Contribution Rate reflect values observed as of February 28, 2015, following the first two paydays but prior to the rollout of phone surveys or secondary interventions. Dependent variable in third panel is total contributions made by the employee to M-Pasandaz, in Afghanis, as observed in administrative data. Value reflects total contributions net of withdrawals as of July 15, 2015, just prior to the disbursement of matching incentives. Value does not include matching contributions made by the employer. Robust standard errors reported in parentheses. 


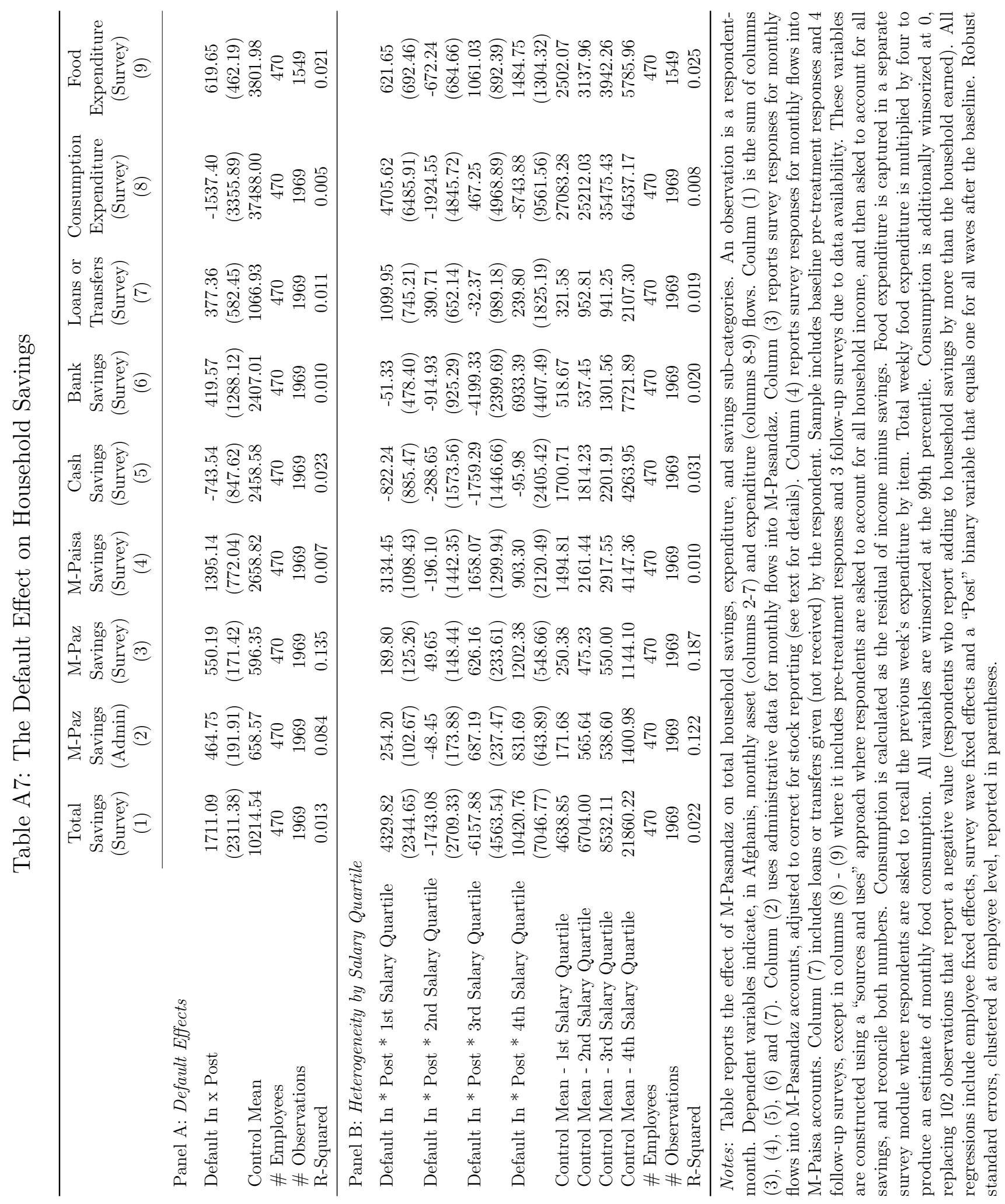


Table A8: The Default Effect on Asset Ownership

\begin{tabular}{|c|c|c|c|c|c|c|}
\hline & \multicolumn{2}{|c|}{ Baseline } & \multicolumn{2}{|c|}{ Endline } & \multirow[b]{2}{*}{$\begin{array}{l}\text { Mean } \\
\text { Difference }\end{array}$} & \multirow[b]{2}{*}{$\begin{array}{l}\text { Difference in } \\
\text { Difference }\end{array}$} \\
\hline & $\begin{array}{l}\text { Default } \\
\text { Out }\end{array}$ & $\begin{array}{l}\text { Default } \\
\text { In }\end{array}$ & $\begin{array}{l}\text { Default } \\
\text { Out }\end{array}$ & $\begin{array}{l}\text { Default } \\
\text { In }\end{array}$ & & \\
\hline Asset Index & $\begin{array}{l}0.04 \\
{[2.25]}\end{array}$ & $\begin{array}{l}-0.04 \\
{[2.18]}\end{array}$ & $\begin{array}{l}0.01 \\
{[2.25]}\end{array}$ & $\begin{array}{l}-0.01 \\
{[2.27]}\end{array}$ & $\begin{array}{l}0.03 \\
(0.16)\end{array}$ & $\begin{array}{l}0.05 \\
(0.13)\end{array}$ \\
\hline Rooms (\#) & $\begin{array}{l}3.31 \\
{[2.08]}\end{array}$ & $\begin{array}{l}3.23 \\
{[1.98]}\end{array}$ & $\begin{array}{l}3.74 \\
{[2.23]}\end{array}$ & $\begin{array}{l}3.58 \\
{[1.77]}\end{array}$ & $\begin{array}{l}0.16 \\
(0.14)\end{array}$ & $\begin{array}{l}-0.09 \\
(0.15)\end{array}$ \\
\hline Beds $(\#)$ & $\begin{array}{l}0.81 \\
{[1.16]}\end{array}$ & $\begin{array}{l}0.77 \\
{[1.17]}\end{array}$ & $\begin{array}{l}0.80 \\
{[1.24]}\end{array}$ & $\begin{array}{l}0.92 \\
{[1.32]}\end{array}$ & $\begin{array}{l}-0.11 \\
(0.09)\end{array}$ & $\begin{array}{l}0.15 \\
(0.09)\end{array}$ \\
\hline Air Conditioners (\#) & $\begin{array}{l}0.21 \\
{[0.80]}\end{array}$ & $\begin{array}{l}0.19 \\
{[0.63]}\end{array}$ & $\begin{array}{l}0.33 \\
{[0.82]}\end{array}$ & $\begin{array}{l}0.38 \\
{[0.85]}\end{array}$ & $\begin{array}{l}-0.05 \\
(0.06)\end{array}$ & $\begin{array}{l}0.08 \\
(0.06)\end{array}$ \\
\hline Heaters $(\#)$ & $\begin{array}{l}1.31 \\
{[1.38]}\end{array}$ & $\begin{array}{l}1.25 \\
{[1.17]}\end{array}$ & $\begin{array}{l}1.21 \\
{[1.15]}\end{array}$ & $\begin{array}{l}1.32 \\
{[1.30]}\end{array}$ & $\begin{array}{l}-0.11 \\
(0.09)\end{array}$ & $\begin{array}{l}0.16 \\
(0.09)\end{array}$ \\
\hline Stoves $(\#)$ & $\begin{array}{l}1.38 \\
{[0.89]}\end{array}$ & $\begin{array}{l}1.39 \\
{[0.99]}\end{array}$ & $\begin{array}{l}1.35 \\
{[1.04]}\end{array}$ & $\begin{array}{l}1.41 \\
{[0.87]}\end{array}$ & $\begin{array}{l}-0.05 \\
(0.07)\end{array}$ & $\begin{array}{l}0.10 \\
(0.08)\end{array}$ \\
\hline Washing Machines (\#) & $\begin{array}{l}1.05 \\
{[0.62]}\end{array}$ & $\begin{array}{l}1.02 \\
{[0.55]}\end{array}$ & $\begin{array}{l}1.10 \\
{[0.72]}\end{array}$ & $\begin{array}{l}1.09 \\
{[0.59]}\end{array}$ & $\begin{array}{l}0.01 \\
(0.05)\end{array}$ & $\begin{array}{l}0.03 \\
(0.04)\end{array}$ \\
\hline Refrigerators (\#) & $\begin{array}{l}0.86 \\
{[0.66]}\end{array}$ & $\begin{array}{l}0.87 \\
{[0.59]}\end{array}$ & $\begin{array}{l}1.00 \\
{[0.60]}\end{array}$ & $\begin{array}{l}0.94 \\
{[0.59]}\end{array}$ & $\begin{array}{l}0.06 \\
(0.04)\end{array}$ & $\begin{array}{l}-0.08 \\
(0.04)\end{array}$ \\
\hline Sewing Machines (\#) & $\begin{array}{l}1.10 \\
{[0.77]}\end{array}$ & $\begin{array}{l}1.07 \\
{[0.77]}\end{array}$ & $\begin{array}{l}1.09 \\
{[0.85]}\end{array}$ & $\begin{array}{l}1.09 \\
{[0.67]}\end{array}$ & $\begin{array}{l}-0.00 \\
(0.05)\end{array}$ & $\begin{array}{l}0.01 \\
(0.05)\end{array}$ \\
\hline Televisions (\#) & $\begin{array}{l}1.76 \\
{[1.07]}\end{array}$ & $\begin{array}{l}1.76 \\
{[1.11]}\end{array}$ & $\begin{array}{l}1.88 \\
{[1.25]}\end{array}$ & $\begin{array}{l}1.87 \\
{[1.17]}\end{array}$ & $\begin{array}{l}0.01 \\
(0.08)\end{array}$ & $\begin{array}{l}-0.01 \\
(0.07)\end{array}$ \\
\hline VCR/DVD Players (\#) & $\begin{array}{l}0.61 \\
{[0.86]}\end{array}$ & $\begin{array}{l}0.66 \\
{[0.86]}\end{array}$ & $\begin{array}{l}0.64 \\
{[0.93]}\end{array}$ & $\begin{array}{l}0.66 \\
{[0.89]}\end{array}$ & $\begin{array}{l}-0.01 \\
(0.06)\end{array}$ & $\begin{array}{l}-0.03 \\
(0.07)\end{array}$ \\
\hline Mobile Phones (\#) & $\begin{array}{l}4.97 \\
{[2.59]}\end{array}$ & $\begin{array}{l}4.85 \\
{[2.91]}\end{array}$ & $\begin{array}{l}4.70 \\
{[2.77]}\end{array}$ & $\begin{array}{l}4.49 \\
{[2.79]}\end{array}$ & $\begin{array}{l}0.21 \\
(0.20)\end{array}$ & $\begin{array}{l}-0.07 \\
(0.18)\end{array}$ \\
\hline Computers (\#) & $\begin{array}{l}1.40 \\
{[1.17]}\end{array}$ & $\begin{array}{l}1.36 \\
{[1.08]}\end{array}$ & $\begin{array}{l}1.38 \\
{[1.11]}\end{array}$ & $\begin{array}{l}1.42 \\
{[1.14]}\end{array}$ & $\begin{array}{l}-0.04 \\
(0.08)\end{array}$ & $\begin{array}{l}0.09 \\
(0.07)\end{array}$ \\
\hline Bicycles (\#) & $\begin{array}{l}0.82 \\
{[0.91]}\end{array}$ & $\begin{array}{l}0.76 \\
{[0.96]}\end{array}$ & $\begin{array}{l}0.86 \\
{[0.95]}\end{array}$ & $\begin{array}{l}0.77 \\
{[0.92]}\end{array}$ & $\begin{array}{l}0.09 \\
(0.07)\end{array}$ & $\begin{array}{l}-0.01 \\
(0.06)\end{array}$ \\
\hline Motorcycles (\#) & $\begin{array}{l}0.17 \\
{[0.51]}\end{array}$ & $\begin{array}{l}0.21 \\
{[0.51]}\end{array}$ & $\begin{array}{l}0.16 \\
{[0.50]}\end{array}$ & $\begin{array}{l}0.18 \\
{[0.46]}\end{array}$ & $\begin{array}{l}-0.02 \\
(0.03)\end{array}$ & $\begin{array}{l}-0.01 \\
(0.03)\end{array}$ \\
\hline Automobiles (\#) & $\begin{array}{l}0.41 \\
{[0.56]}\end{array}$ & $\begin{array}{l}0.41 \\
{[0.62]}\end{array}$ & $\begin{array}{l}0.45 \\
{[0.61]}\end{array}$ & $\begin{array}{l}0.43 \\
{[0.64]}\end{array}$ & $\begin{array}{l}0.02 \\
(0.04)\end{array}$ & $\begin{array}{l}-0.03 \\
(0.04)\end{array}$ \\
\hline Livestock (\#) & $\begin{array}{l}0.54 \\
{[2.78]}\end{array}$ & $\begin{array}{l}0.52 \\
{[2.86]}\end{array}$ & $\begin{array}{l}0.60 \\
{[2.24]}\end{array}$ & $\begin{array}{l}0.34 \\
{[1.39]}\end{array}$ & $\begin{array}{l}0.27 \\
(0.13)\end{array}$ & $\begin{array}{l}-0.28 \\
(0.22)\end{array}$ \\
\hline Observations & 473 & 467 & 409 & 404 & & \\
\hline
\end{tabular}

Notes: Standard deviations reported in brackets and standard errors reported in parentheses. Asset Index is the first principal component of the full set of asset variables below. Columns (1) and (2) report mean values during the baseline survey in October 2014 for default out and default in groups, respectively. Columns (3) and (4) report mean values during the endline survey in August 2015 for default out and default in groups, respectively. Column (5) reports the difference in means and standard error from a t-test comparing default out and default in groups at endline, while Column (6) reports the coefficient and standard errors from a difference-in-difference estimate comparing default out and default in groups between endline and baseline. 


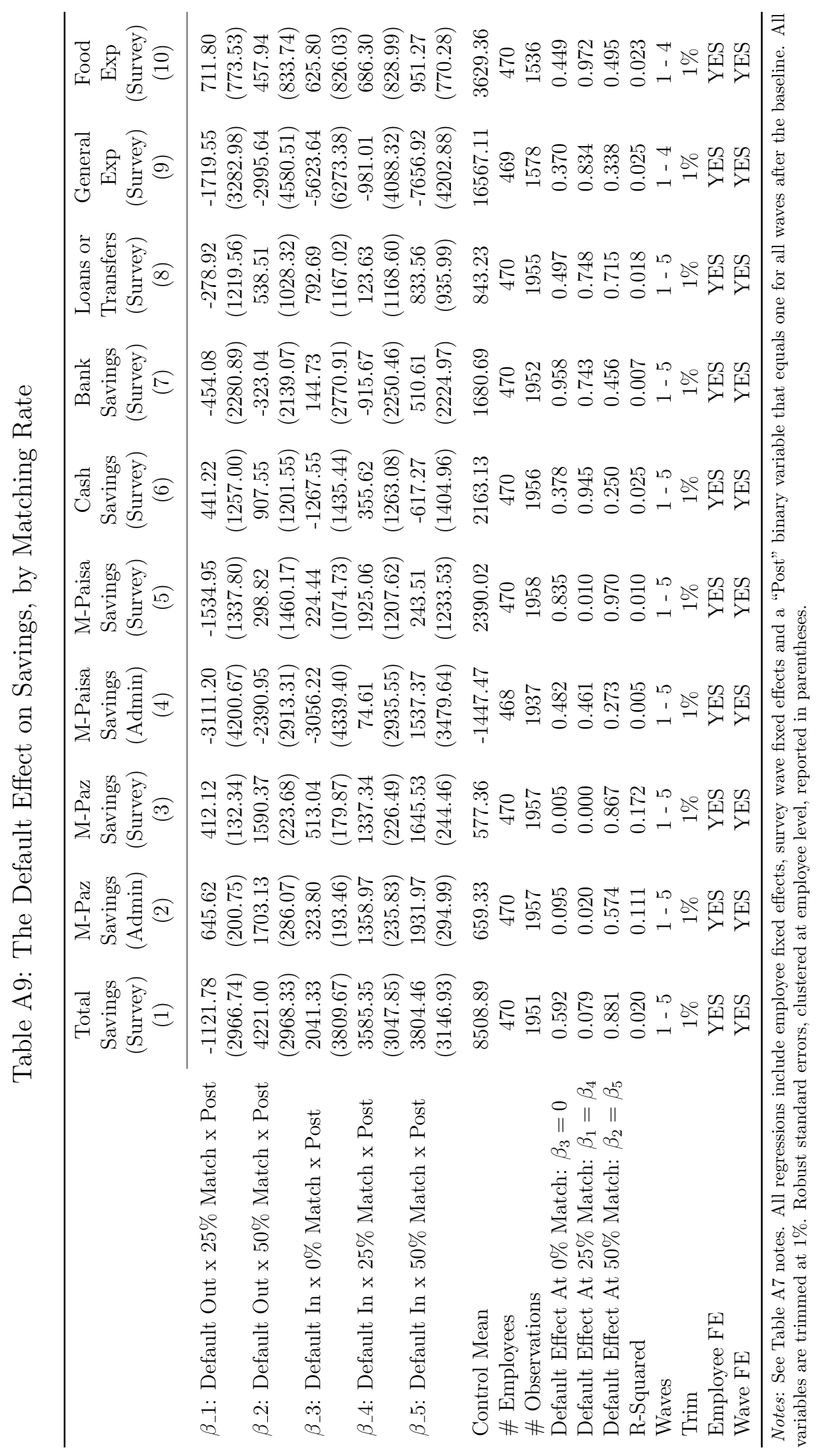


Table A10: Long Term Effect of Defaults on M-Paz Balances by Quarter

\begin{tabular}{|c|c|c|c|c|}
\hline & $(1)$ & $(2)$ & $(3)$ & $(4)$ \\
\hline \multicolumn{5}{|c|}{ Panel A. Dependent Variable = M-Pazandaz Monthly Participation $(=1)$} \\
\hline \multirow[t]{2}{*}{ Defaulted In X 2015:Q1 (During Study) } & 0.440 & 0.495 & 0.472 & 0.346 \\
\hline & $(0.028)$ & $(0.039)$ & $(0.048)$ & $(0.046)$ \\
\hline \multirow[t]{2}{*}{ Defaulted In X 2015:Q2 (During Study) } & 0.330 & 0.366 & 0.374 & 0.234 \\
\hline & $(0.031)$ & $(0.045)$ & $(0.053)$ & $(0.050)$ \\
\hline \multirow[t]{2}{*}{ Defaulted In X 2015:Q3 (Post Study) } & 0.077 & 0.114 & 0.047 & 0.064 \\
\hline & $(0.035)$ & $(0.059)$ & $(0.059)$ & $(0.062)$ \\
\hline \multirow[t]{2}{*}{ Defaulted In X 2015:Q4 (Post Study) } & 0.076 & 0.108 & 0.063 & 0.052 \\
\hline & $(0.038)$ & $(0.065)$ & $(0.064)$ & $(0.068)$ \\
\hline \multirow[t]{2}{*}{ Defaulted In X 2016:Q1 (Post Study) } & 0.083 & 0.098 & 0.088 & 0.062 \\
\hline & $(0.039)$ & $(0.067)$ & $(0.066)$ & $(0.069)$ \\
\hline \multirow{2}{*}{ Defaulted In X 2016:Q2 (Post Study) } & 0.075 & 0.099 & 0.084 & 0.040 \\
\hline & $(0.039)$ & $(0.067)$ & $(0.067)$ & $(0.070)$ \\
\hline \multirow[t]{2}{*}{ Defaulted In X 2016:Q3 (Post Study) } & 0.070 & 0.105 & 0.072 & 0.031 \\
\hline & $(0.040)$ & $(0.068)$ & $(0.067)$ & $(0.072)$ \\
\hline \multirow[t]{2}{*}{ Defaulted In X 2016:Q4 (Post Study) } & 0.049 & 0.066 & 0.055 & 0.027 \\
\hline & $(0.040)$ & $(0.068)$ & $(0.067)$ & $(0.071)$ \\
\hline Employer Match & Complete & $0 \%$ & $25 \%$ & $50 \%$ \\
\hline Month FE & YES & YES & YES & YES \\
\hline Employee FE & YES & YES & YES & YES \\
\hline \# Employees & 943 & 318 & 315 & 310 \\
\hline \# Observations & 15932 & 5297 & 5436 & 5199 \\
\hline R-Squared & 0.07 & 0.10 & 0.08 & 0.11 \\
\hline \multicolumn{5}{|c|}{ Panel B. Dependent Variable = M-Pazandaz Monthly Balance (AFs) } \\
\hline & $(1)$ & $(2)$ & $(3)$ & $(4)$ \\
\hline \multirow[t]{2}{*}{ Defaulted In X 2015:Q1 (During Study) } & 1276.151 & 1451.145 & 1232.411 & 1149.819 \\
\hline & $(243.711)$ & $(266.035)$ & $(426.033)$ & $(497.305)$ \\
\hline \multirow{2}{*}{ Defaulted In X 2015:Q2 (During Study) } & 2181.255 & 2328.027 & 2548.884 & 1676.520 \\
\hline & $(619.173)$ & $(558.224)$ & $(1103.583)$ & $(1289.838)$ \\
\hline \multirow[t]{2}{*}{ Defaulted In X 2015:Q3 (Post Study) } & 1101.753 & 437.328 & 1910.186 & 854.693 \\
\hline & $(424.186)$ & $(319.477)$ & $(884.962)$ & $(830.137)$ \\
\hline \multirow{2}{*}{ Defaulted In X 2015:Q4 (Post Study) } & 937.288 & 62.507 & 2298.533 & 251.866 \\
\hline & $(508.617)$ & $(770.410)$ & $(883.006)$ & $(963.910)$ \\
\hline \multirow[t]{2}{*}{ Defaulted In X 2016:Q1 (Post Study) } & 291.542 & -101.046 & 481.555 & 437.174 \\
\hline & $(542.742)$ & $(875.935)$ & $(801.500)$ & $(1129.017)$ \\
\hline \multirow[t]{2}{*}{ Defaulted In X 2016:Q2 (Post Study) } & 214.531 & 733.462 & -103.568 & 1.781 \\
\hline & $(569.544)$ & $(1043.831)$ & $(909.243)$ & $(1035.179)$ \\
\hline \multirow[t]{2}{*}{ Defaulted In X 2016:Q3 (Post Study) } & 216.215 & 1122.238 & -57.349 & -427.992 \\
\hline & $(577.237)$ & $(1173.663)$ & $(905.239)$ & $(941.989)$ \\
\hline \multirow[t]{2}{*}{ Defaulted In X 2016:Q4 (Post Study) } & 689.448 & 1390.079 & 662.317 & 9.217 \\
\hline & $(660.593)$ & $(1254.212)$ & $(1112.137)$ & $(1078.826)$ \\
\hline Employer Match & Complete & $0 \%$ & $25 \%$ & $50 \%$ \\
\hline Month FE & YES & YES & YES & YES \\
\hline Employee FE & YES & YES & YES & YES \\
\hline \# Employees & 949 & 319 & 316 & 314 \\
\hline \# Observations & 17051 & 5672 & 5805 & 5574 \\
\hline R-Squared & 0.03 & 0.02 & 0.04 & 0.07 \\
\hline
\end{tabular}

Notes: Dependent variable in top panel is the monthly participation decision to contribute to the M-Pasandaz account, and in the bottom panel is the M-Pasandaz balance at the end of each month (in Afghanis, or AFs). Each observation is a respondent-month. All regressions include employee fixed effects and month fixed effects. Robust standard errors, clustered at employee level, reported in parentheses. 
Table A11: The Default Effect on Savings Behaviors and Attitudes, by Match Rate

\begin{tabular}{lccccc}
\hline Outcome: & $\begin{array}{c}\text { Control } \\
\text { Mean }\end{array}$ & $\begin{array}{c}\text { Default } \\
\text { Effect }\end{array}$ & $\begin{array}{c}\text { Naive } \\
\text { p-Value }\end{array}$ & $\begin{array}{c}\text { List et al } \\
\text { p-Value }\end{array}$ & $\begin{array}{c}\text { Bonferonni } \\
\text { p-Value }\end{array}$ \\
\hline Panel A: Composite Indices (0\% Match) & & & & & \\
$\quad$ Importance of Saving Index & -0.143 & 0.259 & 0.003 & 0.006 & 0.007 \\
Financial Security Index & -0.007 & 0.118 & 0.080 & 0.147 & 0.235 \\
Well-Being Index & 0.091 & 0.021 & 0.727 & 0.732 & 1 \\
Panel B: Composite Indices (25\% Match) & & & & & \\
Importance of Saving Index & 0.056 & 0.003 & 0.966 & 0.966 & 1 \\
Financial Security Index & -0.002 & 0.110 & 0.120 & 0.297 & 0.347 \\
$\quad$ Well-Being Index & -0.018 & 0.038 & 0.557 & 0.801 & 1 \\
Panel C: Composite Indices (50\% Match) & & & & & \\
Importance of Saving Index & 0.071 & 0.147 & 0.044 & 0.103 & 0.112 \\
Financial Security Index & 0.022 & 0.091 & 0.190 & 0.332 & 0.566 \\
$\quad$ Well-Being Index & -0.032 & 0.004 & 0.949 & 0.946 & 1 \\
\hline
\end{tabular}

Notes: See Table 3 notes. 


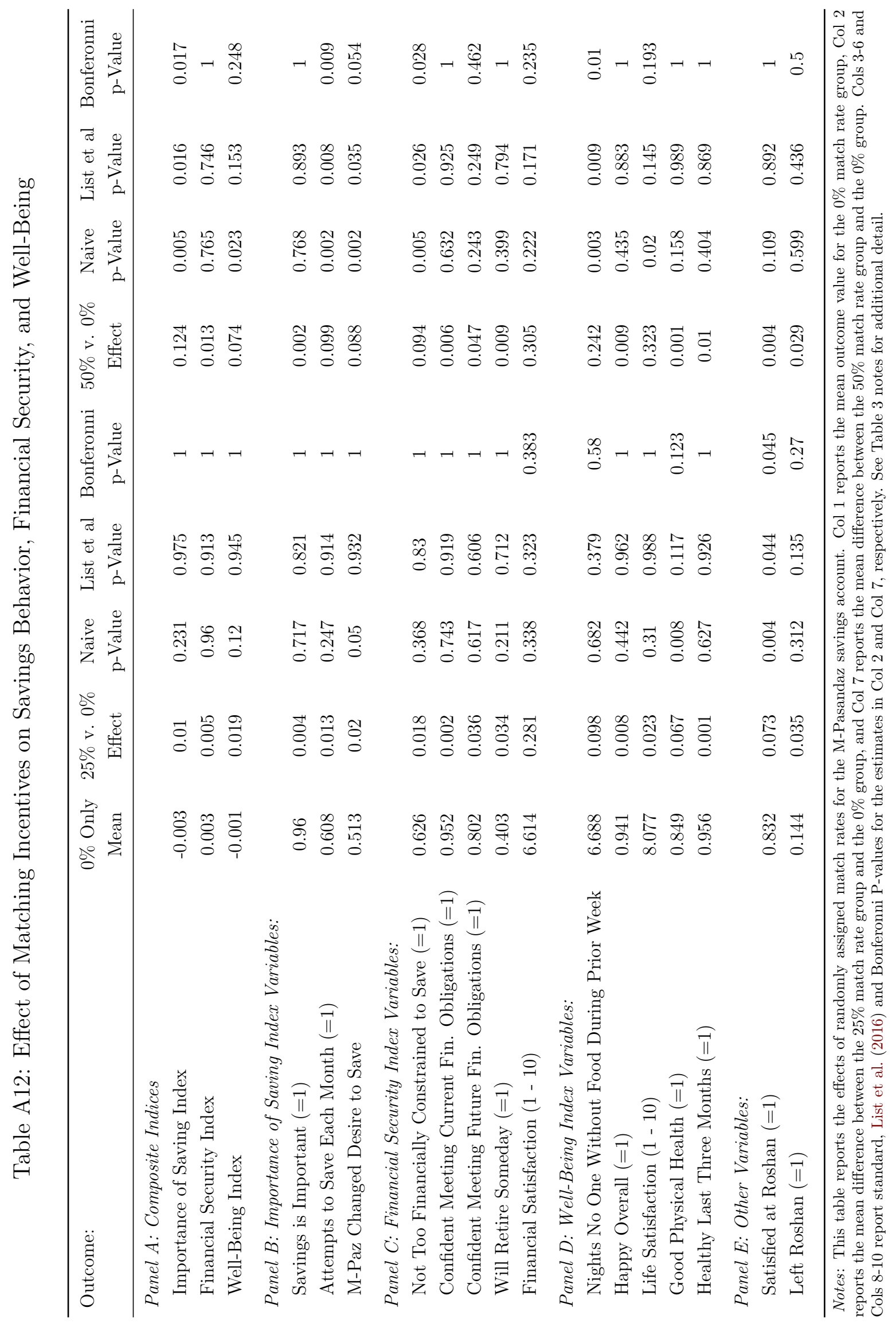




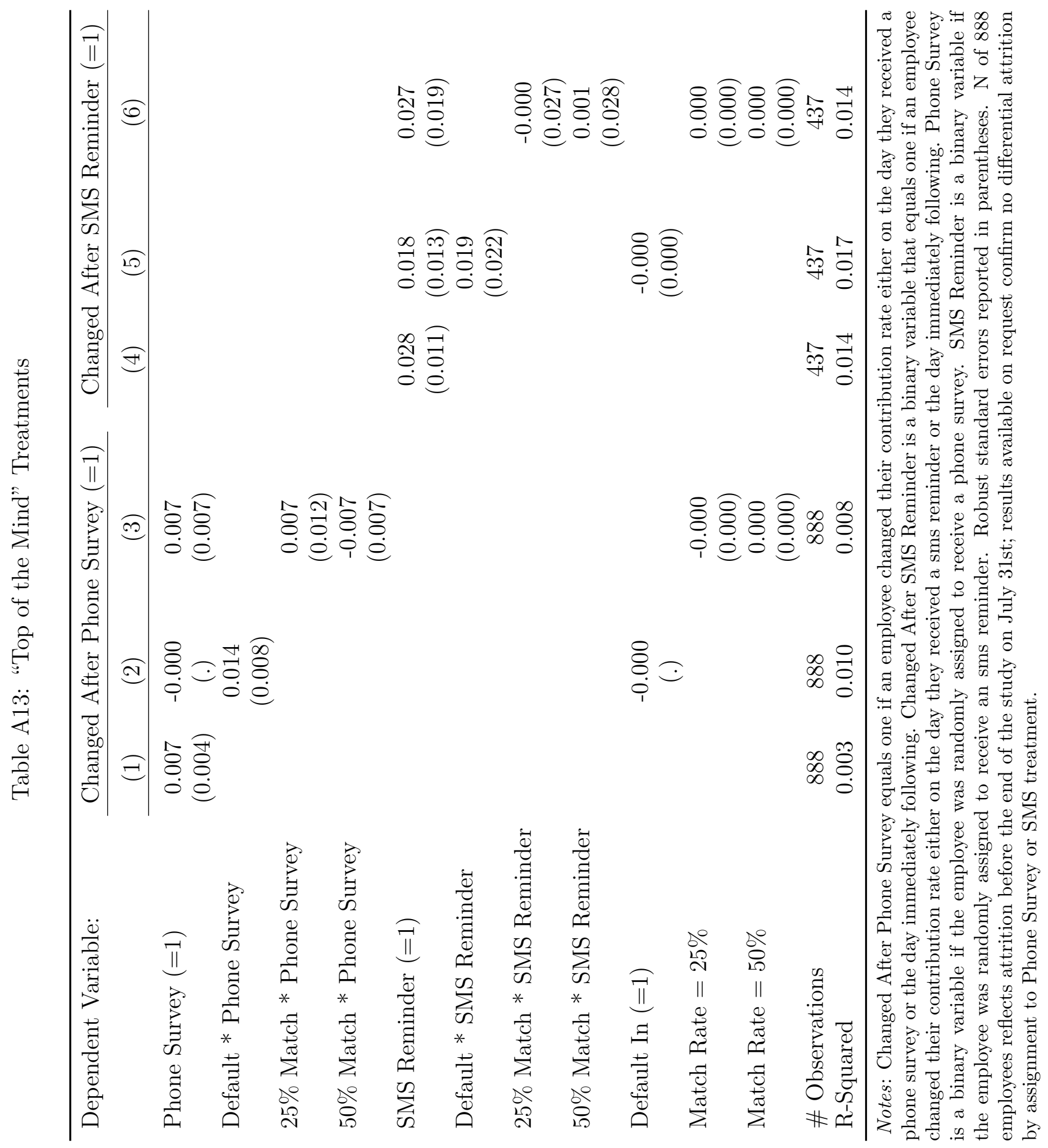


Table A14: Present Bias and Contribution Changes (Unincentivized Baseline Measure)

\begin{tabular}{|c|c|c|c|c|}
\hline \multirow[t]{2}{*}{ Dependent Variable: } & \multicolumn{2}{|c|}{ Still at Default on February 28} & \multicolumn{2}{|c|}{$\begin{array}{c}\text { Still at Default and } \\
\text { No Withdrawal on Feb. } 28\end{array}$} \\
\hline & (1) & (2) & $(3)$ & (4) \\
\hline Present Bias Parameter $(\beta)$ & $\begin{array}{l}-0.510 \\
(0.161)\end{array}$ & $\begin{array}{l}-0.460 \\
(0.170)\end{array}$ & $\begin{array}{l}-0.457 \\
(0.169)\end{array}$ & $\begin{array}{l}-0.407 \\
(0.179)\end{array}$ \\
\hline Long Run Discount Factor $(\delta)$ & & $\begin{array}{l}-0.147 \\
(0.288)\end{array}$ & & $\begin{array}{l}-0.146 \\
(0.294)\end{array}$ \\
\hline Cognitive Reflection Test (0-3) & & $\begin{array}{l}-0.051 \\
(0.023)\end{array}$ & & $\begin{array}{l}-0.049 \\
(0.022)\end{array}$ \\
\hline Risk Preference (1-10) & & $\begin{array}{c}0.002 \\
(0.006)\end{array}$ & & $\begin{array}{l}0.003 \\
(0.006)\end{array}$ \\
\hline Salary (1000 Afs) & & $\begin{array}{c}0.001 \\
(0.001)\end{array}$ & & $\begin{array}{c}0.001 \\
(0.001)\end{array}$ \\
\hline Tenure at Roshan (Years) & & $\begin{array}{l}-0.013 \\
(0.006)\end{array}$ & & $\begin{array}{l}-0.009 \\
(0.006)\end{array}$ \\
\hline Male $(=1)$ & & $\begin{array}{l}0.025 \\
(0.052)\end{array}$ & & $\begin{array}{c}0.033 \\
(0.052)\end{array}$ \\
\hline Education Level & & $\begin{array}{l}-0.001 \\
(0.017)\end{array}$ & & $\begin{array}{l}-0.007 \\
(0.017)\end{array}$ \\
\hline Uses a Bank Account $(=1)$ & & $\begin{array}{l}-0.041 \\
(0.037)\end{array}$ & & $\begin{array}{l}-0.045 \\
(0.038)\end{array}$ \\
\hline Withdraws Entire Salary on Payday $(=1)$ & & $\begin{array}{c}0.008 \\
(0.037)\end{array}$ & & $\begin{array}{l}0.006 \\
(0.037)\end{array}$ \\
\hline Capable of Fixing Phone $(=1)$ & & $\begin{array}{c}0.051 \\
(0.035)\end{array}$ & & $\begin{array}{c}0.039 \\
(0.036)\end{array}$ \\
\hline Constant & $\begin{array}{c}1.075 \\
(0.156)\end{array}$ & $\begin{array}{l}1.210 \\
(0.309)\end{array}$ & $\begin{array}{c}0.977 \\
(0.164)\end{array}$ & $\begin{array}{l}1.120 \\
(0.319)\end{array}$ \\
\hline $\begin{array}{l}\text { R-Squared } \\
\text { \# Employees }\end{array}$ & $\begin{array}{c}0.010 \\
829\end{array}$ & $\begin{array}{c}0.025 \\
804\end{array}$ & $\begin{array}{c}0.008 \\
829\end{array}$ & $\begin{array}{c}0.020 \\
804\end{array}$ \\
\hline
\end{tabular}

Notes: This table reports on the variables that predict whether a participant remains at their default election on February 28 , 2015 , two months after the start of the experiment. $\beta$ is a measure of present bias obtained using a hypothetical price list at baseline. The remaining variables are described in Appendix D.2. Robust standard errors reported in parentheses. 
Table A15: Present Bias and Contribution Changes - Heterogeneity by Default Assignment

\begin{tabular}{|c|c|c|c|c|}
\hline \multirow[t]{2}{*}{ Dependent Variable: } & \multicolumn{2}{|c|}{ Still at Default on February 28} & \multicolumn{2}{|c|}{$\begin{array}{c}\text { Still at Default and } \\
\text { No Withdrawal on Feb. } 28\end{array}$} \\
\hline & (1) & $(2)$ & $(3)$ & $(4)$ \\
\hline Present Bias Parameter $(\beta)$ & $\begin{array}{l}-0.143 \\
(0.064)\end{array}$ & $\begin{array}{l}-0.163 \\
(0.064)\end{array}$ & $\begin{array}{l}-0.143 \\
(0.064)\end{array}$ & $\begin{array}{l}-0.163 \\
(0.064)\end{array}$ \\
\hline Default In $\mathrm{x} \beta$ & $\begin{array}{l}-0.003 \\
(0.103)\end{array}$ & $\begin{array}{c}0.037 \\
(0.102)\end{array}$ & $\begin{array}{c}0.094 \\
(0.103)\end{array}$ & $\begin{array}{c}0.132 \\
(0.102)\end{array}$ \\
\hline Defaulted In $(=1)$ & $\begin{array}{l}-0.263 \\
(0.109)\end{array}$ & $\begin{array}{l}-0.057 \\
(0.243)\end{array}$ & $\begin{array}{l}-0.454 \\
(0.109)\end{array}$ & $\begin{array}{l}-0.234 \\
(0.242)\end{array}$ \\
\hline Default In $\mathrm{x} \delta$ & & $\begin{array}{c}0.035 \\
(0.106)\end{array}$ & & $\begin{array}{c}0.043 \\
(0.111)\end{array}$ \\
\hline Long Run Discount Factor $(\delta)$ & & $\begin{array}{l}-0.004 \\
(0.072)\end{array}$ & & $\begin{array}{l}-0.004 \\
(0.072)\end{array}$ \\
\hline Default In x Cognitive Reflection Test & & $\begin{array}{c}0.009 \\
(0.050)\end{array}$ & & $\begin{array}{l}-0.001 \\
(0.046)\end{array}$ \\
\hline Cognitive Reflection Test (0-3) & & $\begin{array}{l}-0.050 \\
(0.034)\end{array}$ & & $\begin{array}{l}-0.050 \\
(0.034)\end{array}$ \\
\hline Default In x Risk Preference & & $\begin{array}{c}0.025 \\
(0.012)\end{array}$ & & $\begin{array}{c}0.028 \\
(0.011)\end{array}$ \\
\hline Risk Preference (1-10) & & $\begin{array}{l}-0.002 \\
(0.007)\end{array}$ & & $\begin{array}{l}-0.002 \\
(0.007)\end{array}$ \\
\hline Default In x Salary & & $\begin{array}{c}0.000 \\
(0.002)\end{array}$ & & $\begin{array}{c}0.000 \\
(0.002)\end{array}$ \\
\hline Salary (1000 Afs) & & $\begin{array}{c}0.000 \\
(0.001)\end{array}$ & & $\begin{array}{c}0.000 \\
(0.001)\end{array}$ \\
\hline Default In x Tenure at Roshan & & $\begin{array}{l}-0.015 \\
(0.014)\end{array}$ & & $\begin{array}{l}-0.008 \\
(0.013)\end{array}$ \\
\hline Tenure at Roshan (Years) & & $\begin{array}{l}-0.004 \\
(0.009)\end{array}$ & & $\begin{array}{l}-0.004 \\
(0.009)\end{array}$ \\
\hline Default In x Male & & $\begin{array}{l}-0.127 \\
(0.110)\end{array}$ & & $\begin{array}{l}-0.142 \\
(0.109)\end{array}$ \\
\hline Male (=1) & & $\begin{array}{c}0.095 \\
(0.080)\end{array}$ & & $\begin{array}{c}0.095 \\
(0.080)\end{array}$ \\
\hline Default In x Education Level & & $\begin{array}{l}-0.047 \\
(0.035)\end{array}$ & & $\begin{array}{l}-0.053 \\
(0.034)\end{array}$ \\
\hline Education Level & & $\begin{array}{c}0.022 \\
(0.024)\end{array}$ & & $\begin{array}{c}0.022 \\
(0.024)\end{array}$ \\
\hline Default In x Uses a Bank Account & & $\begin{array}{c}0.002 \\
(0.079)\end{array}$ & & $\begin{array}{c}0.007 \\
(0.079)\end{array}$ \\
\hline Uses a Bank Account $(=1)$ & & $\begin{array}{l}-0.036 \\
(0.053)\end{array}$ & & $\begin{array}{l}-0.036 \\
(0.053)\end{array}$ \\
\hline Default In x Withdraws Entire Salary on Payday & & $\begin{array}{l}-0.084 \\
(0.077)\end{array}$ & & $\begin{array}{l}-0.064 \\
(0.076)\end{array}$ \\
\hline Withdraws Entire Salary on Payday $(=1)$ & & $\begin{array}{c}0.072 \\
(0.052)\end{array}$ & & $\begin{array}{c}0.072 \\
(0.052)\end{array}$ \\
\hline Default In x Capable of Fixing Phone & & $\begin{array}{c}0.061 \\
(0.075)\end{array}$ & & $\begin{array}{c}0.003 \\
(0.074)\end{array}$ \\
\hline Capable of Fixing Phone $(=1)$ & & $\begin{array}{c}0.030 \\
(0.051)\end{array}$ & & $\begin{array}{c}0.030 \\
(0.051)\end{array}$ \\
\hline Constant & $\begin{array}{c}0.870 \\
(0.068)\end{array}$ & $\begin{array}{c}0.738 \\
(0.165)\end{array}$ & $\begin{array}{c}0.870 \\
(0.068)\end{array}$ & $\begin{array}{c}0.738 \\
(0.165)\end{array}$ \\
\hline $\begin{array}{l}\text { Control Mean } \\
\text { \# Employees } \\
\text { R-Squared }\end{array}$ & $\begin{array}{c}0.72 \\
702 \\
0.082\end{array}$ & $\begin{array}{c}0.73 \\
678 \\
0.121\end{array}$ & $\begin{array}{c}0.72 \\
702 \\
0.135\end{array}$ & $\begin{array}{c}0.73 \\
678 \\
0.169\end{array}$ \\
\hline
\end{tabular}

Notes: See Table 5 notes. Robust standard errors reported in parentheses. 
Table A16: The Default Effect: Additional Heterogeneity

\begin{tabular}{|c|c|c|c|c|c|c|c|c|c|c|c|c|c|}
\hline & & & & & & Part & icipates ( & $=1)$ & & & & & \\
\hline & (1) & (2) & (3) & (4) & (5) & (6) & (7) & (8) & (9) & (10) & (11) & (12) & (13) \\
\hline Default In $(=1)$ & $\begin{array}{c}0.413 \\
(0.034)\end{array}$ & $\begin{array}{c}0.365 \\
(0.046)\end{array}$ & $\begin{array}{l}0.495 \\
(0.076)\end{array}$ & $\begin{array}{c}0.439 \\
(0.043)\end{array}$ & $\begin{array}{c}0.448 \\
(0.063)\end{array}$ & $\begin{array}{c}0.410 \\
(0.050)\end{array}$ & $\begin{array}{c}0.435 \\
(0.072)\end{array}$ & $\begin{array}{l}0.399 \\
(0.088)\end{array}$ & $\begin{array}{c}0.416 \\
(0.135)\end{array}$ & $\begin{array}{c}0.392 \\
(0.045)\end{array}$ & $\begin{array}{c}0.413 \\
(0.045)\end{array}$ & $\begin{array}{c}0.372 \\
(0.048)\end{array}$ & $\begin{array}{c}0.565 \\
(0.213)\end{array}$ \\
\hline Default In x Present Biased & & $\begin{array}{c}0.117 \\
(0.069)\end{array}$ & & & & & & & & & & & $\begin{array}{c}0.095 \\
(0.074)\end{array}$ \\
\hline Default In x Impatient & & & $\begin{array}{l}-0.099 \\
(0.085)\end{array}$ & & & & & & & & & & $\begin{array}{l}-0.107 \\
(0.089)\end{array}$ \\
\hline Default In x Cognitive Reflection Test & & & & $\begin{array}{l}-0.049 \\
(0.045)\end{array}$ & & & & & & & & & $\begin{array}{l}-0.037 \\
(0.050)\end{array}$ \\
\hline Default In x Risk Preference & & & & & $\begin{array}{l}-0.007 \\
(0.011)\end{array}$ & & & & & & & & $\begin{array}{l}-0.005 \\
(0.011)\end{array}$ \\
\hline Default In x Salary & & & & & & $\begin{array}{c}0.000 \\
(0.000)\end{array}$ & & & & & & & $\begin{array}{c}0.000 \\
(0.000)\end{array}$ \\
\hline Default In x Tenure at Roshan & & & & & & & $\begin{array}{l}-0.004 \\
(0.011)\end{array}$ & & & & & & $\begin{array}{l}-0.009 \\
(0.013)\end{array}$ \\
\hline Default In x Male & & & & & & & & $\begin{array}{c}0.013 \\
(0.096)\end{array}$ & & & & & $\begin{array}{l}-0.045 \\
(0.102)\end{array}$ \\
\hline Default In x Education Level & & & & & & & & & $\begin{array}{l}0.000 \\
(0.027)\end{array}$ & & & & $\begin{array}{l}-0.016 \\
(0.032)\end{array}$ \\
\hline Default In x Uses a Bank Account & & & & & & & & & & $\begin{array}{c}0.048 \\
(0.070)\end{array}$ & & & $\begin{array}{l}0.020 \\
(0.075)\end{array}$ \\
\hline Default In x Withdraws Entire Salary on Payday & & & & & & & & & & & $\begin{array}{l}-0.002 \\
(0.070)\end{array}$ & & $\begin{array}{c}0.027 \\
(0.074)\end{array}$ \\
\hline Default In x Capable of Fixing Phone & & & & & & & & & & & & $\begin{array}{c}0.092 \\
(0.069)\end{array}$ & $\begin{array}{c}0.119 \\
(0.072)\end{array}$ \\
\hline Present Biased (=1) & & $\begin{array}{c}-0.083 \\
(0.048)\end{array}$ & & & & & & & & & & & $\begin{array}{l}-0.085 \\
(0.049)\end{array}$ \\
\hline Impatient $(=1)$ & & & $\begin{array}{c}0.021 \\
(0.057)\end{array}$ & & & & & & & & & & $\begin{array}{l}-0.009 \\
(0.059)\end{array}$ \\
\hline Cognitive Reflection Test (0-3) & & & & $\begin{array}{c}0.052 \\
(0.032)\end{array}$ & & & & & & & & & $\begin{array}{c}0.052 \\
(0.034)\end{array}$ \\
\hline Risk Preference (1-10) & & & & & $\begin{array}{c}0.004 \\
(0.007)\end{array}$ & & & & & & & & $\begin{array}{c}0.002 \\
(0.007)\end{array}$ \\
\hline Salary & & & & & & $\begin{array}{c}0.000 \\
(0.000)\end{array}$ & & & & & & & $\begin{array}{c}0.000 \\
(0.000)\end{array}$ \\
\hline Tenure at Roshan (Years) & & & & & & & $\begin{array}{c}0.003 \\
(0.008)\end{array}$ & & & & & & $\begin{array}{c}0.002 \\
(0.009)\end{array}$ \\
\hline Male $(=1)$ & & & & & & & & $\begin{array}{l}-0.106 \\
(0.074)\end{array}$ & & & & & $\begin{array}{l}-0.087 \\
(0.079)\end{array}$ \\
\hline Education Level & & & & & & & & & $\begin{array}{l}-0.017 \\
(0.019)\end{array}$ & & & & $\begin{array}{c}-0.024 \\
(0.024)\end{array}$ \\
\hline Uses a Bank Account & & & & & & & & & & $\begin{array}{c}0.014 \\
(0.049)\end{array}$ & & & $\begin{array}{l}0.036 \\
(0.054)\end{array}$ \\
\hline Withdraws Entire Salary on Payday & & & & & & & & & & & $\begin{array}{c}-0.036 \\
(0.048)\end{array}$ & & $\begin{array}{l}-0.058 \\
(0.052)\end{array}$ \\
\hline Capable of Fixing Phone & & & & & & & & & & & & $\begin{array}{c}-0.016 \\
(0.048)\end{array}$ & $\begin{array}{c}-0.033 \\
(0.050)\end{array}$ \\
\hline Constant & $\begin{array}{c}0.276 \\
(0.024)\end{array}$ & $\begin{array}{c}0.310 \\
(0.032)\end{array}$ & $\begin{array}{c}0.260 \\
(0.050)\end{array}$ & $\begin{array}{c}0.248 \\
(0.029)\end{array}$ & $\begin{array}{c}0.259 \\
(0.041)\end{array}$ & $\begin{array}{c}0.263 \\
(0.038)\end{array}$ & $\begin{array}{c}0.258 \\
(0.050)\end{array}$ & $\begin{array}{c}0.367 \\
(0.069)\end{array}$ & $\begin{array}{c}0.352 \\
(0.094)\end{array}$ & $\begin{array}{c}0.271 \\
(0.030)\end{array}$ & $\begin{array}{c}0.291 \\
(0.032)\end{array}$ & $\begin{array}{c}0.284 \\
(0.033)\end{array}$ & $\begin{array}{c}0.480 \\
(0.151)\end{array}$ \\
\hline \# Observations & 702 & 702 & 702 & 693 & 701 & 702 & 689 & 702 & 701 & 702 & 702 & 702 & 678 \\
\hline R-Squared & 0.171 & 0.175 & 0.173 & 0.173 & 0.171 & 0.172 & 0.169 & 0.176 & 0.174 & 0.173 & 0.172 & 0.174 & 0.197 \\
\hline
\end{tabular}


Table A17: Which Element of the Consultation is Associated with Switching: Heterogeneity

\begin{tabular}{|c|c|c|c|c|}
\hline \multirow[t]{2}{*}{ Dependent Variable: } & \multicolumn{4}{|c|}{$\begin{array}{c}\text { Changed Contribution } \\
\text { After February } 28(=1)\end{array}$} \\
\hline & $(1)$ & $(2)$ & $(3)$ & $(4)$ \\
\hline \multicolumn{5}{|l|}{ Panel A: Assigned Consultation } \\
\hline Assigned Consultation $(=1)$ & $\begin{array}{c}0.091 \\
(0.018)\end{array}$ & $\begin{array}{l}-0.006 \\
(0.015)\end{array}$ & $\begin{array}{c}0.061 \\
(0.021)\end{array}$ & $\begin{array}{c}0.039 \\
(0.034)\end{array}$ \\
\hline Assigned Consultation x Still at Default & & $\begin{array}{c}0.165 \\
(0.027)\end{array}$ & & $\begin{array}{c}0.031 \\
(0.040)\end{array}$ \\
\hline Assigned Consultation x Defaulted In & & & $\begin{array}{c}0.060 \\
(0.031)\end{array}$ & $\begin{array}{l}-0.068 \\
(0.034)\end{array}$ \\
\hline Assigned Consultation x Still at Default x Defaulted In & & & & $\begin{array}{c}0.298 \\
(0.062)\end{array}$ \\
\hline Constant & $\begin{array}{c}0.037 \\
(0.009)\end{array}$ & $\begin{array}{c}0.037 \\
(0.009)\end{array}$ & $\begin{array}{c}0.037 \\
(0.009)\end{array}$ & $\begin{array}{c}0.037 \\
(0.009)\end{array}$ \\
\hline R-squared & 0.027 & 0.071 & 0.033 & 0.123 \\
\hline \# Employees & 927 & 927 & 927 & 927 \\
\hline \multicolumn{5}{|l|}{ Panel B: Accepted Consultation } \\
\hline Accepted Consultation $(=1)$ & $\begin{array}{c}0.154 \\
(0.024)\end{array}$ & $\begin{array}{c}0.028 \\
(0.022)\end{array}$ & $\begin{array}{c}0.124 \\
(0.030)\end{array}$ & $\begin{array}{c}0.079 \\
(0.043)\end{array}$ \\
\hline Accepted Consultation x Still at Default & & $\begin{array}{c}0.214 \\
(0.036)\end{array}$ & & $\begin{array}{c}0.066 \\
(0.054)\end{array}$ \\
\hline Accepted Consultation x Defaulted In & & & $\begin{array}{c}0.060 \\
(0.042)\end{array}$ & $\begin{array}{l}-0.084 \\
(0.043)\end{array}$ \\
\hline Accepted Consultation x Still at Default x Defaulted In & & & & $\begin{array}{c}0.312 \\
(0.078)\end{array}$ \\
\hline Constant & $\begin{array}{c}0.017 \\
(0.012)\end{array}$ & $\begin{array}{c}0.017 \\
(0.012)\end{array}$ & $\begin{array}{c}0.017 \\
(0.012)\end{array}$ & $\begin{array}{c}0.017 \\
(0.012)\end{array}$ \\
\hline R-squared & 0.040 & 0.112 & 0.046 & 0.165 \\
\hline \# Employees & 443 & 443 & 443 & 443 \\
\hline \multicolumn{5}{|l|}{ Panel C: Calculation Assistance } \\
\hline Calculation Assistance $(=1)$ & $\begin{array}{c}0.439 \\
(0.054)\end{array}$ & $\begin{array}{c}0.143 \\
(0.071)\end{array}$ & $\begin{array}{c}0.362 \\
(0.069)\end{array}$ & $\begin{array}{c}0.193 \\
(0.095)\end{array}$ \\
\hline Calculation Assistance x Still at Default & & $\begin{array}{c}0.447 \\
(0.092)\end{array}$ & & $\begin{array}{c}0.277 \\
(0.128)\end{array}$ \\
\hline Calculation Assistance x Defaulted In & & & $\begin{array}{c}0.178 \\
(0.102)\end{array}$ & $\begin{array}{l}-0.147 \\
(0.128)\end{array}$ \\
\hline Calculation Assistance x Still at Default x Defaulted In & & & & $\begin{array}{c}0.399 \\
(0.174)\end{array}$ \\
\hline Constant & $\begin{array}{c}0.045 \\
(0.015)\end{array}$ & $\begin{array}{c}0.045 \\
(0.015)\end{array}$ & $\begin{array}{c}0.045 \\
(0.015)\end{array}$ & $\begin{array}{c}0.045 \\
(0.015)\end{array}$ \\
\hline R-squared & 0.278 & 0.373 & 0.294 & 0.398 \\
\hline \# Employees & 295 & 295 & 295 & 295 \\
\hline
\end{tabular}

Notes: See Table 6 notes. This table reports which elements of the financial consultation predict whether an employee switches their contribution. Robust standard errors are reported in parentheses. 
Table A18: Consultation Offer and Present Bias (Unincentivized Baseline Measure)

\begin{tabular}{|c|c|c|c|c|c|}
\hline & \multicolumn{5}{|c|}{ Accepted Consultation $(=1)$} \\
\hline & $(1)$ & $(2)$ & $(3)$ & $(4)$ & $(5)$ \\
\hline Consult Later & $\begin{array}{c}0.063 \\
(0.045)\end{array}$ & $\begin{array}{c}0.067 \\
(0.045)\end{array}$ & $\begin{array}{c}0.064 \\
(0.053)\end{array}$ & $\begin{array}{c}0.042 \\
(0.064)\end{array}$ & $\begin{array}{c}0.395 \\
(0.251)\end{array}$ \\
\hline Present Biased $(=1)$ & & & $\begin{array}{l}-0.048 \\
(0.074)\end{array}$ & $\begin{array}{l}-0.051 \\
(0.076)\end{array}$ & $\begin{array}{l}-0.058 \\
(0.077)\end{array}$ \\
\hline Consult Later x Present Biased & & & $\begin{array}{c}0.018 \\
(0.100)\end{array}$ & $\begin{array}{l}-0.002 \\
(0.101)\end{array}$ & $\begin{array}{c}0.015 \\
(0.103)\end{array}$ \\
\hline Impatient $(=1)$ & & & & $\begin{array}{c}0.009 \\
(0.070)\end{array}$ & $\begin{array}{c}0.008 \\
(0.071)\end{array}$ \\
\hline Consult Later x Cognitive Reflection Test & & & & & $\begin{array}{l}-0.022 \\
(0.058)\end{array}$ \\
\hline Consult Later x Risk Preference & & & & & $\begin{array}{c}0.001 \\
(0.016)\end{array}$ \\
\hline Consult Later x Salary & & & & & $\begin{array}{l}-0.003 \\
(0.002)\end{array}$ \\
\hline Consult Later x Tenure at Roshan & & & & & $\begin{array}{l}-0.004 \\
(0.017)\end{array}$ \\
\hline Consult Later x Male & & & & & $\begin{array}{l}-0.214 \\
(0.148)\end{array}$ \\
\hline Consult Later x Education Level & & & & & $\begin{array}{l}-0.014 \\
(0.042)\end{array}$ \\
\hline Consult Later x Uses a Bank Account & & & & & $\begin{array}{c}0.094 \\
(0.096)\end{array}$ \\
\hline Consult Later x Withdraws Entire Salary on Payday & & & & & $\begin{array}{l}-0.042 \\
(0.096)\end{array}$ \\
\hline Consult Later x Capable of Fixing Phone & & & & & $\begin{array}{l}-0.005 \\
(0.097)\end{array}$ \\
\hline Constant & $\begin{array}{c}0.716 \\
(0.032)\end{array}$ & $\begin{array}{c}0.820 \\
(0.120)\end{array}$ & $\begin{array}{c}0.829 \\
(0.122)\end{array}$ & $\begin{array}{c}0.827 \\
(0.122)\end{array}$ & $\begin{array}{c}0.631 \\
(0.174)\end{array}$ \\
\hline Control Mean & 0.76 & 0.76 & 0.76 & 0.76 & 0.76 \\
\hline Covariates & No & Yes & Yes & Yes & Yes \\
\hline \# Observations & 380 & 380 & 380 & 380 & 380 \\
\hline R-Squared & 0.005 & 0.036 & 0.038 & 0.041 & 0.063 \\
\hline
\end{tabular}

Notes: Accepted Consultation Offer $(=1)$ is a binary variable that equals one if the employee agreed to participation in a financial consultation regarding their participation in the M-Pasandaz program (see paper text for details). Consult Later $(=1)$ is a binary variable that equals zero if the employee was randomly assigned to receive a consultation on the same day as the consultation offer was made, and equals one if the consultation was assigned to take place one week later. Present Biased (=1) is a binary variable that equals one if an employee is identified as having $\beta<1$ in an unincentivized present bias elicitation completed at baseline and Impatient $(=1)$ is a binary variable that equals one if an employee is identified as having $\delta<1$ (see paper text for details). Columns (2), (4) and (5) include covariates for cognitive reflection task, risk preference, salary, tenure at Roshan, gender, education level, uses a bank account, withdraws entire salary on payday, and capable of fixing a phone - see Appendix D.2 for questions. Robust standard errors reported in parentheses. 
Table A19: Which Treatments Move Participants From Their Default Contribution?

\begin{tabular}{|c|c|c|c|}
\hline \multirow[t]{2}{*}{ Dependent Variable: } & \multicolumn{3}{|c|}{$\begin{array}{c}\text { Changed Contribution } \\
\text { After Feb. } 28(=1)\end{array}$} \\
\hline & (1) & $(2)$ & $(3)$ \\
\hline Financial Consultation $(=1)$ & $\begin{array}{c}0.097 \\
(0.020)\end{array}$ & $\begin{array}{c}0.033 \\
(0.013)\end{array}$ & $\begin{array}{c}0.066 \\
(0.033)\end{array}$ \\
\hline Financial Consultation x Still at Default & & $\begin{array}{c}0.109 \\
(0.034)\end{array}$ & \\
\hline Financial Consultation x Defaulted In & & & $\begin{array}{c}0.195 \\
(0.068)\end{array}$ \\
\hline SMS Reminder $(=1)$ & $\begin{array}{c}0.014 \\
(0.019)\end{array}$ & $\begin{array}{c}0.011 \\
(0.011)\end{array}$ & $\begin{array}{l}-0.002 \\
(0.030)\end{array}$ \\
\hline SMS x Still at Default & & $\begin{array}{c}0.006 \\
(0.032)\end{array}$ & \\
\hline SMS x Defaulted In & & & $\begin{array}{c}0.060 \\
(0.070)\end{array}$ \\
\hline Still at Default $(=1)$ & & $\begin{array}{c}0.053 \\
(0.020)\end{array}$ & \\
\hline Defaulted In $(=1)$ & & & $\begin{array}{c}0.037 \\
(0.043)\end{array}$ \\
\hline Constant & $\begin{array}{c}0.032 \\
(0.012)\end{array}$ & $\begin{array}{c}0.000 \\
(0.000)\end{array}$ & $\begin{array}{c}0.038 \\
(0.022)\end{array}$ \\
\hline R-squared & 0.026 & 0.073 & 0.103 \\
\hline \# Employees & 888 & 888 & 526 \\
\hline Sample & Full & Full & $\begin{array}{l}\text { Still } \\
\text { at Default }\end{array}$ \\
\hline
\end{tabular}

Notes: This table reports the comparative effectiveness of different treatments designed to move participants from their default election. SMS Reminder is a dummy variable equal to one for participants receiving an SMS reminder message, Consultation is dummy equal to one for subjects receiving an offer of a financial consultation, Still at Default is a dummy variable equal to one for participants who have not moved from their default election, and $\beta$ is a measure of present-bias obtained from a hypothetical price list experiment at baseline. $\mathrm{N}$ of 888 employees reflects attrition before the end of the study on July 31st; results available on request confirm no differential attrition by assignment to Consultation or SMS treatment. Robust standard errors reported in parentheses. 
Table B1: The Default Effect on Total Contributions (incl. strata fixed effects)

\begin{tabular}{|c|c|c|c|c|}
\hline & (1) & $(2)$ & (3) & (4) \\
\hline \multicolumn{5}{|c|}{ Panel A. Dependent Variable $=$ Participates (non-zero contribution rate } \\
\hline \multirow[t]{2}{*}{ Default In $(=1)$} & 0.41 & 0.47 & 0.45 & 0.30 \\
\hline & $(0.03)$ & $(0.04)$ & $(0.05)$ & $(0.05)$ \\
\hline \multirow[t]{2}{*}{ Constant } & 0.24 & -0.01 & 0.22 & 0.52 \\
\hline & $(0.04)$ & $(0.05)$ & $(0.07)$ & $(0.08)$ \\
\hline Sample & Complete & $0 \%$ Match & $25 \%$ Match & $50 \%$ Match \\
\hline \# Observations & 935 & 315 & 311 & 309 \\
\hline R-Squared & 0.193 & 0.377 & 0.280 & 0.246 \\
\hline \multicolumn{5}{|c|}{ Panel B. Dependent Variable = Contribution Rate $(\%$ of Salary $)$} \\
\hline \multirow[t]{2}{*}{ Default In $(=1)$} & 1.80 & 2.39 & 2.33 & 0.64 \\
\hline & $(0.26)$ & $(0.22)$ & $(0.47)$ & $(0.47)$ \\
\hline \multirow[t]{2}{*}{ Constant } & 2.33 & -0.06 & 1.94 & 5.25 \\
\hline & $(0.37)$ & $(0.26)$ & $(0.63)$ & $(0.76)$ \\
\hline Sample & Complete & $0 \%$ Match & 25\% Match & $50 \%$ Match \\
\hline \# Observations & 935 & 315 & 311 & 309 \\
\hline R-Squared & 0.091 & 0.369 & 0.194 & 0.164 \\
\hline \multicolumn{5}{|c|}{ Panel C. Dependent Variable $=$ Total M-Pasandaz Contributions (Afs) } \\
\hline \multirow[t]{2}{*}{ Default In $(=1)$} & 2578.78 & 2230.65 & 3291.81 & 2377.44 \\
\hline & $(707.45)$ & $(662.61)$ & $(1299.58)$ & $(1368.33)$ \\
\hline \multirow[t]{2}{*}{ Constant } & 790.86 & -542.47 & 313.46 & 2558.15 \\
\hline & $(454.77)$ & $(392.81)$ & $(819.92)$ & $(910.81)$ \\
\hline Sample & Complete & $0 \%$ Match & $25 \%$ Match & $50 \%$ Match \\
\hline \# Observations & 948 & 319 & 315 & 314 \\
\hline R-Squared & 0.168 & 0.118 & 0.236 & 0.332 \\
\hline
\end{tabular}

Notes: Dependent variable in top panel, Participates $(=1)$, is a binary variable that equals one if the contribution rate is greater than zero, and dependent variable in middle panel, Contribution Rate (\% of Salary), is the monthy contribution rate into M-Pasandaz as a percent of total salary. Participates and Contribution Rate reflect values observed as of February 28, 2015, following the first two paydays but prior to the rollout of phone surveys or secondary interventions. Dependent variable in third panel is total contributions made by the employee to M-Pasandaz, in Afghanis, as observed in administrative data. Value reflects total contributions net of withdrawals as of July 15, 2015, just prior to the disbursement of matching incentives. Value does not include matching contributions made by the employer. Stratum fixed effects are included. Robust standard errors reported in parentheses. 
Table B2: The Default Effect on Active Decision at Trial End (incl. strata fixed effects)

\begin{tabular}{lcccc}
\hline & \multicolumn{4}{c}{ Continued M-Pasandaz After Program $(=1)$} \\
& $(1)$ & $(2)$ & $(3)$ & $(4)$ \\
\hline Default In (=1) & 0.10 & 0.16 & 0.07 & 0.10 \\
& $(0.03)$ & $(0.06)$ & $(0.06)$ & $(0.06)$ \\
Constant & 0.34 & 0.20 & 0.38 & 0.45 \\
& $(0.05)$ & $(0.08)$ & $(0.09)$ & $(0.10)$ \\
Sample & Complete & $0 \%$ Match & $25 \%$ Match & $50 \%$ Match \\
\# Observations & 810 & 272 & 276 & 262 \\
R-Squared & 0.081 & 0.110 & 0.136 & 0.103 \\
\hline
\end{tabular}

Notes: Dependent variable is a binary indicator that equals one if the employee made an active decision to continued contributing to the M-Pasandaz after the 6 month study ended with no matching incentives offered. Stratum fixed effects are included. Robust standard errors reported in parentheses. 
Table B3: Which Element of the Consultation is Associated with Switching (incl. strata fixed effects)?

\begin{tabular}{|c|c|c|c|c|}
\hline \multirow[t]{2}{*}{ Dependent Variable: } & \multicolumn{4}{|c|}{$\begin{array}{l}\text { Changed Contribution } \\
\text { After February } 28(=1)\end{array}$} \\
\hline & (1) & $(2)$ & $(3)$ & (4) \\
\hline Assigned Consultation $(=1)$ & $\begin{array}{c}0.091 \\
(0.018)\end{array}$ & & & \\
\hline Accepted Consultation $(=1)$ & & $\begin{array}{c}0.157 \\
(0.025)\end{array}$ & & \\
\hline Did Not Delay Consultation $(=1)$ & & & $\begin{array}{l}-0.098 \\
(0.260)\end{array}$ & $\begin{array}{l}-0.097 \\
(0.264)\end{array}$ \\
\hline Asked for Overview of M-Paz $(=1)$ & & & $\begin{array}{c}0.050 \\
(0.047)\end{array}$ & $\begin{array}{c}0.072 \\
(0.052)\end{array}$ \\
\hline Initial Questions about M-Paz $(=1)$ & & & $\begin{array}{c}0.052 \\
(0.050)\end{array}$ & $\begin{array}{c}0.057 \\
(0.055)\end{array}$ \\
\hline Aware of M-Paz Plan and Rate $(=1)$ & & & $\begin{array}{l}-0.146 \\
(0.092)\end{array}$ & $\begin{array}{l}-0.166 \\
(0.106)\end{array}$ \\
\hline Asked to Repeat Projected Balance $(=1)$ & & & $\begin{array}{c}0.128 \\
(0.066)\end{array}$ & $\begin{array}{c}0.124 \\
(0.071)\end{array}$ \\
\hline Calculation Assistance $(=1)$ & & & $\begin{array}{c}0.394 \\
(0.059)\end{array}$ & $\begin{array}{c}0.408 \\
(0.060)\end{array}$ \\
\hline Additional Questions about M-Paz (=1) & & & $\begin{array}{c}0.036 \\
(0.059)\end{array}$ & $\begin{array}{c}0.019 \\
(0.066)\end{array}$ \\
\hline Control Mean & 0.06 & 0.10 & 0.15 & 0.16 \\
\hline Covariates & $\mathrm{NO}$ & $\mathrm{NO}$ & $\mathrm{NO}$ & YES \\
\hline R-squared & 0.036 & 0.057 & 0.347 & 0.365 \\
\hline \# Employees & 927 & 443 & 295 & 287 \\
\hline
\end{tabular}

Notes: This table reports which elements of the financial consultation predict whether an employee switches their contribution. 469 of the 928 employees still active in our study at the time of this intervention were assigned to be offered a consultation, establishing the sample for column (1). Of these, 443 employees answered the call making the initial offer, establishing the sample for column (2). Of these 443, 327 employees agreed to a full consultation. Accepted Consultation is a dummy variable equal to 1 for these employees. Of the 327 employees who accepted the consultation, 295 were reached by the second caller offering the consultation, forming the sample for column (3). Of the 295 employees who both accepted and who were reached for a consultation, all completed the consultation. 291 were able to talk immediately (Did Not Delay Consultation=1), while 4 could not and were reached later. 259 requested an overview of the M-Pasandaz product (Asked for Overview of M-Paz=1), while 36 did not. 91 employees had initial questions about the M-Pasandaz product (Initial Questions about M$\mathrm{Paz}=1$ ), while 204 did not. 285 confirmed that they were aware of their plan and contribution rate (Aware of M-Paz Plan and Rate=1), while 10 were not. All were informed of their projected balance after six months including any potential bonus payments, and 52 employees asked for this information to be repeated (Asked to Repeat Projected Balance=1), while 242 did not. All were offered assistance with calculating how much money they would earn in different contribution scenarios, 95 requested assistance (Calculation Assistance=1), while 200 did not. Requesting assistance was not required to change the level of contribution to M-Pasandaz during the consultation call. 53 employees had additional questions about the M-Pasandaz product (Additional Questions about M-Paz=1), while 242 did not. Sample size in column 1 includes full sample subject to attrition when consultation was offered, column 2 sample includes all employees assigned a consultation, column 3 sample includes all employees who accepted a consultation, and column 4 excludes employees missing covariates. The additional covariates are: cognitive reflection test, risk preference, salary, tenure at Roshan, gender, education level, uses a bank account, withdraws entire salary on payday, and capable of fixing a phone. Stratum fixed effects are included. Robust standard errors are reported in parentheses. 


\section{Table B4: Consultation Offer Results By Present Bias (incl. strata fixed effects)}

\begin{tabular}{|c|c|c|c|c|c|}
\hline & \multicolumn{5}{|c|}{ Accepted Consultation $(=1)$} \\
\hline & (1) & $(2)$ & (3) & (4) & $(5)$ \\
\hline Consult Later & $\begin{array}{c}0.078 \\
(0.049)\end{array}$ & $\begin{array}{c}0.079 \\
(0.049)\end{array}$ & $\begin{array}{l}-0.012 \\
(0.067)\end{array}$ & $\begin{array}{c}0.026 \\
(0.133)\end{array}$ & $\begin{array}{c}0.458 \\
(0.274)\end{array}$ \\
\hline Present Biased $(=1)$ & $\begin{array}{c}0.053 \\
(0.048)\end{array}$ & & $\begin{array}{l}-0.050 \\
(0.069)\end{array}$ & $\begin{array}{l}-0.047 \\
(0.070)\end{array}$ & $\begin{array}{l}-0.008 \\
(0.071)\end{array}$ \\
\hline Consult Later x Present Biased & & & $\begin{array}{l}0.218 \\
(0.097)\end{array}$ & $\begin{array}{c}0.211 \\
(0.097)\end{array}$ & $\begin{array}{c}0.162 \\
(0.099)\end{array}$ \\
\hline Impatient $(=1)$ & & & & $\begin{array}{c}0.022 \\
(0.098)\end{array}$ & $\begin{array}{c}0.051 \\
(0.099)\end{array}$ \\
\hline Consult Later x Cognitive Reflection Test & & & & & $\begin{array}{l}-0.048 \\
(0.070)\end{array}$ \\
\hline Consult Later x Risk Preference & & & & & $\begin{array}{l}-0.012 \\
(0.018)\end{array}$ \\
\hline Consult Later x Salary & & & & & $\begin{array}{l}-0.004 \\
(0.002)\end{array}$ \\
\hline Consult Later $\mathrm{x}$ Tenure at Roshan & & & & & $\begin{array}{c}0.005 \\
(0.017)\end{array}$ \\
\hline Consult Later x Male & & & & & $\begin{array}{l}-0.108 \\
(0.156)\end{array}$ \\
\hline Consult Later x Education Level & & & & & $\begin{array}{l}-0.015 \\
(0.040)\end{array}$ \\
\hline Consult Later x Uses a Bank Account & & & & & $\begin{array}{c}0.087 \\
(0.104)\end{array}$ \\
\hline Consult Later x Withdraws Entire Salary on Payday & & & & & $\begin{array}{l}-0.160 \\
(0.098)\end{array}$ \\
\hline Consult Later x Capable of Fixing Phone & & & & & $\begin{array}{l}-0.051 \\
(0.106)\end{array}$ \\
\hline Constant & $\begin{array}{c}0.768 \\
(0.150)\end{array}$ & $\begin{array}{l}0.785 \\
(0.149)\end{array}$ & $\begin{array}{c}0.839 \\
(0.154)\end{array}$ & $\begin{array}{l}0.818 \\
(0.186)\end{array}$ & $\begin{array}{c}0.595 \\
(0.237)\end{array}$ \\
\hline Control Mean & 0.77 & 0.77 & 0.77 & 0.77 & 0.77 \\
\hline Covariates & No & Yes & Yes & Yes & Yes \\
\hline \# Observations & 329 & 329 & 329 & 329 & 329 \\
\hline R-Squared & 0.069 & 0.066 & 0.084 & 0.084 & 0.121 \\
\hline
\end{tabular}

Notes: Accepted Consultation Offer $(=1)$ is a binary variable that equals one if the employee agreed to participation in a financial consultation regarding their participation in the M-Pasandaz program (see paper text for details). Consult Later $(=1)$ is a binary variable that equals zero if the employee was randomly assigned to receive a consultation on the same day as the consultation offer was made, and equals one if the consultation was assigned to take place one week later. Present Biased (=1) is a binary variable that equals one if an employee is identified as having $\beta<1$ in an experimental present bias elicitation completed at endline with real stakes and Impatient $(=1)$ is a binary variable that equals one if an employee is identified as having $\delta<1$ (see paper text for details). Columns (2), (4) and (5) include covariates for cognitive reflection task, risk preference, salary, tenure at Roshan, gender, education level, uses a bank account, withdraws entire salary on payday, and capable of fixing a phone - see Appendix D.2 for questions. Stratum fixed effects are included. Robust standard errors reported in parentheses. 


\section{Experimental Scripts}

\section{D.1 Financial Consultation}

Hello XXX. I am calling on behalf of the M-Pasandaz research team department. I am calling because you recently requested that a representative call you to provide you with additional information about M-Pasandaz, and determine how to use M-Pasandaz in the way that is best for you. This consultation will last roughly 5-10 minutes. Are you able to speak to me now? [RECORD RESPONSE]

Thank you for taking the time to speak with me. As you know, M-Pasandaz is a new benefit that is being offered to Roshan employees. In this call, you will have the opportunity to ask questions about M-Pasandaz. I will provide information about how much savings you would have for different levels of monthly contribution. At the end of the call, you will also have the opportunity to change the level of your contribution if you would like.

First of all, would you like me to give you a brief overview of the M-Pasandaz account? [YES/NO]

If YES: M-Pasandaz is a new benefit for all Roshan employees that was designed to help increase your savings. It is a mobile savings account that is linked to your M-Paisa account. A portion of your monthly salary - up to a maximum of $10 \%$ - can be automatically deposited into your M-Pasandaz account each month. Participating in the M-Pasandaz account is voluntary and you may receive benefits from Roshan to encourage you to save for the future. You can access the money in your M-Pasandaz account at any time, but if you contribute and dont make any withdrawals for 6 months, you may be eligible for a bonus from Roshan as a reward for savings.

To begin, we would like to ask if there are any questions we might answer about MPasandaz. [YES/NO]

Now, since every person has a different situation, I would like to explain several different scenarios, to help you understand how different levels of M-Pasandaz contributions would work for you. According to our records, you are in the [WHITE/BLUE/RED] plan, and you currently have a monthly contribution rate of [XX\%]. Were you aware that this was your plan and contribution rate? [YES/NO]

According to our records, you have a monthly salary of XXX. Since you are in the [WHITE/BLUE/RED] plan, you are eligible to receive a matching contribution Roshan of [0/25/50] percent for all money that you save in your M-Pasandaz account. Our records also show that you [HAVE/HAVE NOT] made a withdrawal from your M-Pasandaz account, meaning that you [ARE NOT/ARE] still eligible to receive your matching contribution. Therefore, if you continue to contribute at your current rate and make no withdrawals, at 
the end of the trial period in July, you would have a total value of MMM in your M-Pasandaz account. This reflects both your contribution and the contribution of Roshan to the account on your behalf. Would you like me to repeat this information for you? [YES/NO]

Thank you. Of course, you are always free to change your monthly contribution rate. If you like, I can explain to you exactly what would happen if you decided to change your match to a different amount. Would you like me assist you by explaining what would happen if you changed your contribution rate to a different amount? [YES/NO]

If YES: What scenario would you like me to explain? The contribution rate can be anywhere between $0 \%$ and $10 \%$ of your monthly salary. [RECORD ANSWER]

Do you have any additional questions about how M-Pasandaz works, or can I provide any additional information that can help you determine how to use M-Pasandaz in the way that is best for you? [YES/NO]

Thank you. Now, I would like to offer you the opportunity to change your contribution rate. If you wish, you can tell me your preferred rate, and I will change it for you. Alternatively, you always have the opportunity to call $\mathrm{HR}$ at a later date and change the contribution. Would you like me to change your contribution rate? [YES/NO]

If YES: What would you like your new rate to be: [RECORD RESPONSE]

Thank you very much for your time. Goodbye. 
D.2 Survey instrument (selected questions) 


\section{Endline survey questions (savings behavior, financial security, and wellbeing)}

Roshan leadership is reviewing the results of the M-Pasandaz pilot program, and will be making a decision in the next few months about its future. In the meantime, we would like to offer you the opportunity to continue to have a portion of your salary deposited automatically in the $\mathrm{M}$ -

Pasandaz account each month. For deposits made starting in August there will be no matching incentive paid, but you are welcome to continue to have part of your salary deducted and placed in savings if you find this useful. For these deposits, you will be free to make withdrawals at any time without penalty.

\begin{tabular}{|c|c|c|c|}
\hline & & \multicolumn{2}{|c|}{$\begin{array}{l}\text { Would you enroll now to have part of your salary deposited each month starting in } \\
\text { August? }\end{array}$} \\
\hline 1 & Yes & 98 & Don't Know \\
\hline 2 & No & 99 & Refuse to Answer \\
\hline
\end{tabular}

\begin{tabular}{|l|l|r|l|}
\hline \multicolumn{2}{|c|}{$\begin{array}{l}\text { How important do you think savings is - extremely important, very important, somewhat } \\
\text { important, not very important, not at all important? }\end{array}$} \\
\hline 1 & $\begin{array}{l}\text { Extremely important } \\
\text { Very } \\
\text { important }\end{array}$ & 4 & Not very important \\
\cline { 1 - 1 } 2 & 5 & Not at all important \\
\hline 3 & Somewhat important & \multicolumn{3}{|c|}{} \\
\hline
\end{tabular}

\begin{tabular}{|l|l|l|l|}
\hline \multicolumn{3}{|c|}{ Do you attempt to save money each month? } \\
\hline 1 & Yes & 98 & Don't Know \\
\cline { 3 - 3 } 2 & No & 98 & Refuse to Answer \\
\hline
\end{tabular}

\begin{tabular}{|l|l|}
\hline \multicolumn{2}{|c|}{$\begin{array}{l}\text { If "1" means you are completely dissatisfied on this scale, and "10" means you are } \\
\text { completely satisfied, where would you put your satisfaction with your household's } \\
\text { financial situation? }\end{array}$} \\
\hline \multicolumn{2}{|c|}{} \\
\hline 99 & Refuse to Answer \\
\hline
\end{tabular}

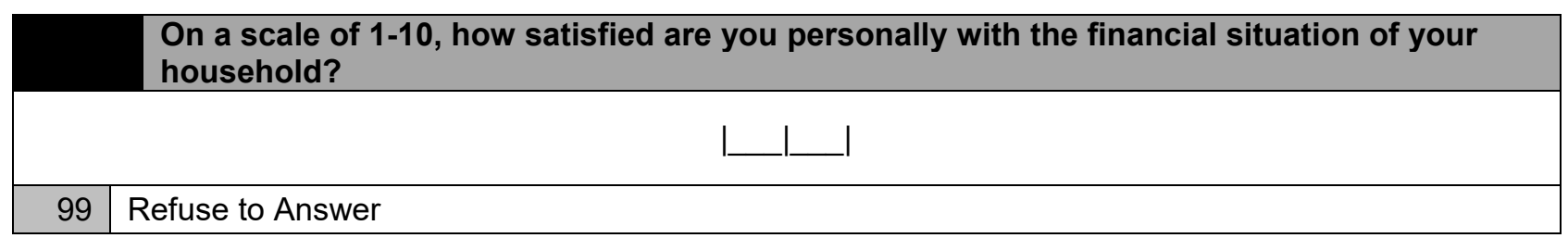




\begin{tabular}{|c|l|r|l|}
\hline & \multicolumn{3}{|l|}{$\begin{array}{l}\text { How confident do you feel that you will be able to meet your financial obligations (pay } \\
\text { your bills, buy food/clothes) during the coming month: Highly confident, somewhat } \\
\text { confident, Somewhat not confident, Not confident at all? }\end{array}$} \\
\hline 1 & $\begin{array}{l}\text { Highly } \\
\text { confident } \\
\text { Somewhat } \\
\text { confident }\end{array}$ & 3 & Some What not confident \\
\cline { 2 - 2 } & 4 & Not confident at all \\
\hline
\end{tabular}

\begin{tabular}{|c|c|c|c|}
\hline & \multicolumn{3}{|c|}{$\begin{array}{l}\text { How confident do you feel that you will be able to meet your financial obligations } 1 \text { year } \\
\text { from now: Highly confident, somewhat confident, Somewhat not confident, Not confident at } \\
\text { all? }\end{array}$} \\
\hline 1 & Highly confident & 3 & Some What not confident \\
\hline 2 & Somewhat confident & 4 & Not confident at all \\
\hline
\end{tabular}

Do you feel that you will be able to someday retire, stop working, and live off of your
accumulated savings?

\begin{tabular}{|l|l|l|l|}
\hline $\begin{array}{l}\text { What prevents you from saving? (not important, too many expenses, benefits are too small, } \\
\text { no place to save, etc) }\end{array}$ \\
\hline 1 & Not important & 3 & Benefits too small \\
\cline { 3 - 4 } & 4 & No place to save \\
\hline 5 & Ooo many expenses & \multicolumn{3}{|l}{} \\
\hline
\end{tabular}

During the last seven days how many times did one or more people in your household not receive a regular daily meal? 
Taking all things together, do you think you are, Very happy, Somewhat happy, little happy or Not at all Happy:

\begin{tabular}{|l|l|l|l|}
\hline 1 & Very happy & 3 & little happy \\
\cline { 3 - 3 } 2 & Somewhat happy & Not at all happy \\
\hline 99 & Refuse to Answer & \multicolumn{2}{|l|}{} \\
\hline
\end{tabular}

All things considered, how satisfied are you with life as a whole? Please tell me your answer on a 10 point scale, where 1 represents Most Dissatisfied, 10 represents Most Satisfied."

\section{0 point scale: $10=$ Satisfied; $1=$ Dissatisfied}

99 Refuse to Answer

\begin{tabular}{|c|c|c|c|}
\hline & \multicolumn{3}{|c|}{$\begin{array}{l}\text { All in all, how would you describe your state of physical health these days? Would you say } \\
\text { it is...? }\end{array}$} \\
\hline 1 & Very good & 4 & Poor \\
\hline 2 & Good & 98 & Don't Know \\
\hline 3 & Fair & & \\
\hline
\end{tabular}

\begin{tabular}{|c|c|c|}
\hline \multicolumn{3}{|c|}{$\begin{array}{l}\text { Over the past } 3 \text { months were you unable to perform normal activities for at least } 7 \text { days due } \\
\text { to an illness/injury? }\end{array}$} \\
\hline Yes & 2 & No \\
\hline
\end{tabular}

\begin{tabular}{|l|l|l|l|}
\hline \multicolumn{3}{|c|}{ Has your participation in M-Pasandaz changed your desire to save? } \\
\hline 1 & Yes & 98 & Don't Know \\
\hline 2 & No & 99 & Refuse to Answer \\
\hline
\end{tabular}




\section{Baseline survey questions (intelligence, risk, preferences)}

If it takes five machines five minutes to make five widgets, how long does it take 100 machines to make 100 widgets?

In a lake, there is a patch of lily pads. Every day, the patch doubles in size. If it takes $\mathbf{4 8}$ days for the patch to cover the entire lake, how long would it take for the patch to cover half of the lake?

Suppose Ahmad earns a salary of 1000 dollars a month. He obtains a ten percent raise this year and a ten percent raise next year. How much exactly will his income be after the second raise?

\begin{tabular}{|l|l|l|l|}
\hline 98 & $\begin{array}{l}\text { Don't } \\
\text { Know }\end{array}$ & 99 & Refuse to Answer \\
\hline
\end{tabular}

There are many decisions we make in life that could lead to a range of outcomes. For example, when we make a business investment, we are not sure that the business will be successful. This phenomenon is called risk. Many decisions involve risk. For example, if you decide to sell a new type of product or service, how much profit will you earn? We are interested in understanding more about how business owners think about risk.

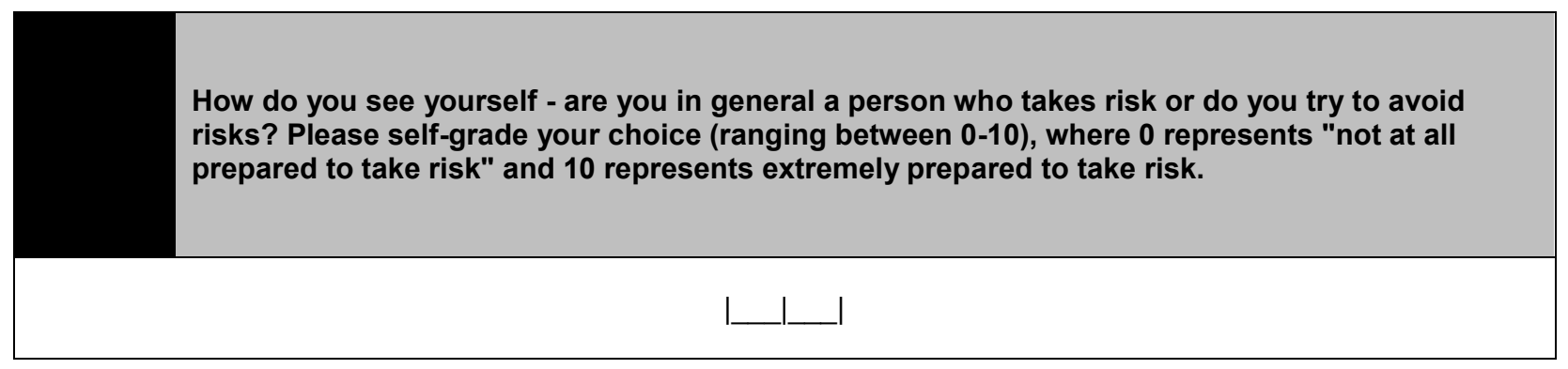

\begin{tabular}{|l|l|r|r|}
\hline \multicolumn{2}{|l|}{ How many bank accounts do you personally do you have? } & & \\
\hline 98 & Don't Know & 99 & Refuse to Answer \\
\hline
\end{tabular}




\begin{tabular}{|l|l|l|l|}
\hline & $\begin{array}{l}\text { If you had a technical problem with your cell phone, who would you mainly ask for help? (for } \\
\text { example if your phone would not turn on or allow you to make calles) }\end{array}$ \\
\hline 1 & $\begin{array}{l}\text { I can fix it myself } \\
\text { A relative } \\
\text { A neighbor or friend }\end{array}$ & 4 & Cell phone retailer/repair shop \\
\hline 3 & 5 & I would purchase a new phone \\
\hline 6 & Other (Specify) & & \\
\hline
\end{tabular}

\begin{tabular}{|c|c|}
\hline & $\begin{array}{l}\text { Do you withdraw your entire salary e } \\
\text { on M-paisa? }\end{array}$ \\
\hline 1 & Withdraw entire monthly salary \\
\hline 2 & Leave some fraction on as an M-paisa balance \\
\hline
\end{tabular}




\section{D.3 Present Bias Elicitation}

Below, we provide the survey instrument used to elicit the present bias parameter used in the regression in Table 5. This instrument is a modified version of the time-dated price list method proposed by Andreoni et al. (2015), where payments were made using M-Paisa (mobile money). In our case, the incentivized measure leverages the fact that employees had received their salaries using mobile money for several years, and therefore had a high degree of confidence that they would receive their payments.

As noted in the text, however, this measure may be fungible to respondents (Cubitt and Read, 2007; Chabris et al., 2008; Andreoni and Sprenger, 2012; Augenblick et al., 2015; Carvalho et al., 2014; Andreoni et al., 2016). In addition, we lack endline inconsistency measures for 175 employees, or $18.4 \%$ of our sample. Of these, 131 (13.8\% of sample) did not complete an endline survey - primarily due to leaving Roshan before the end of the experiment. The remaining 44 employees (4.6\% of sample) completed endline surveys but did not complete the inconsistency elicitation.

For this reason, we also separately estimate the regressions in Table 5 using a different measure of present bias, elicited at baseline. In this protocol, subjects were asked: "Suppose someone was going to pay you USD 450 in one month. He/she offers to pay you a lower amount today. What amount today would make you just as happy as receiving USD 450 in one month?" and "Suppose someone was going to pay you USD 450 in 13 months. He/she offers to pay you a lower amount in 12 months time. What amount in 12 months would make you just as happy as receiving USD 450 in 13 months?" We identify someone as presentbiased if the response to the first question is a lower amount than the response to the second question.

Results using this measure of present bias are reported in Table A14, and are qualitatively similar to those in the main text. All employees in our sample completed a baseline survey but 53 employees ( $5.5 \%$ of sample) did not complete the baseline elicitation. 


\section{TODAY and 4 WEEKS from today}

For each decision number ( 1 to 5 ) below, decide the AMOUNTS you would like for sure today AND in 4 weeks by checking the corresponding box.

Example: In Decision 1, if you wanted AFN 250 today and AFN 0 in four weeks you would check the left-most box. Remember to check only one box per decision!

\begin{tabular}{|c|c|c|c|c|}
\hline $\begin{array}{l}1 . \text { Would } \\
\text { you like to } \\
\text { receive }\end{array}$ & $\begin{array}{c}\text { Payment } \\
\text { TODAY } \\
\text { and } \\
\text { payment in } 4 \\
\text { WEEKS }\end{array}$ & $\begin{array}{c}\text { AFN } 250 \\
\text { AFN } 0 \\
\square\end{array}$ & $\begin{array}{c}\text { AFN } 125 \\
\text { AFN } 125 \\
\square\end{array}$ & $\begin{array}{c}\text { AFN } 0 \\
\text { AFN } 250 \\
\square\end{array}$ \\
\hline $\begin{array}{l}2 . \text { Would } \\
\text { you like to } \\
\text { receive }\end{array}$ & $\begin{array}{c}\text { Payment } \\
\text { TODAY } \\
\underline{\text { and }} \\
\text { payment in } 4 \\
\text { WEEKS }\end{array}$ & $\begin{array}{c}\text { AFN } 225 \\
\text { AFN } 0 \\
\square\end{array}$ & $\begin{array}{c}\text { AFN } 113 \\
\text { AFN } 125 \\
\square\end{array}$ & $\begin{array}{c}\text { AFN } 0 \\
\text { AFN } 250 \\
\square\end{array}$ \\
\hline $\begin{array}{l}\text { 3. Would } \\
\text { you like to } \\
\text { receive }\end{array}$ & $\begin{array}{l}\text { Payment } \\
\text { TODAY } \\
\text { and } \\
\text { payment in } 4 \\
\text { WEEKS }\end{array}$ & $\begin{array}{c}\text { AFN } 200 \\
\text { AFN } 0 \\
\square\end{array}$ & $\begin{array}{c}\mathrm{AFN} 125 \\
\square\end{array}$ & $\begin{array}{c}\text { AFN } 0 \\
\text { AFN } 250 \\
\square\end{array}$ \\
\hline $\begin{array}{l}\text { 4. Would } \\
\text { you like to } \\
\text { receive }\end{array}$ & $\begin{array}{l}\text { Payment } \\
\text { TODAY } \\
\text { and } \\
\text { payment in } 4 \\
\text { WEEKS }\end{array}$ & $\begin{array}{c}\text { AFN } 175 \\
\text { AFN } 0 \\
\square\end{array}$ & $\begin{array}{c}\mathrm{AFN} 125 \\
\square\end{array}$ & $\begin{array}{c}\text { AFN } 0 \\
\text { AFN } 250 \\
\square\end{array}$ \\
\hline $\begin{array}{l}5 \text {. Would } \\
\text { you like to } \\
\text { receive }\end{array}$ & $\begin{array}{l}\text { Payment } \\
\text { TODAY } \\
\underline{\text { and }} \\
\text { payment in } 4 \\
\text { WEEKS }\end{array}$ & $\begin{array}{c}\text { AFN } 0 \\
\square\end{array}$ & $\begin{array}{c}\mathrm{AFN} 125 \\
\square\end{array}$ & $\begin{array}{c}\mathrm{AFN} 250 \\
\square\end{array}$ \\
\hline
\end{tabular}




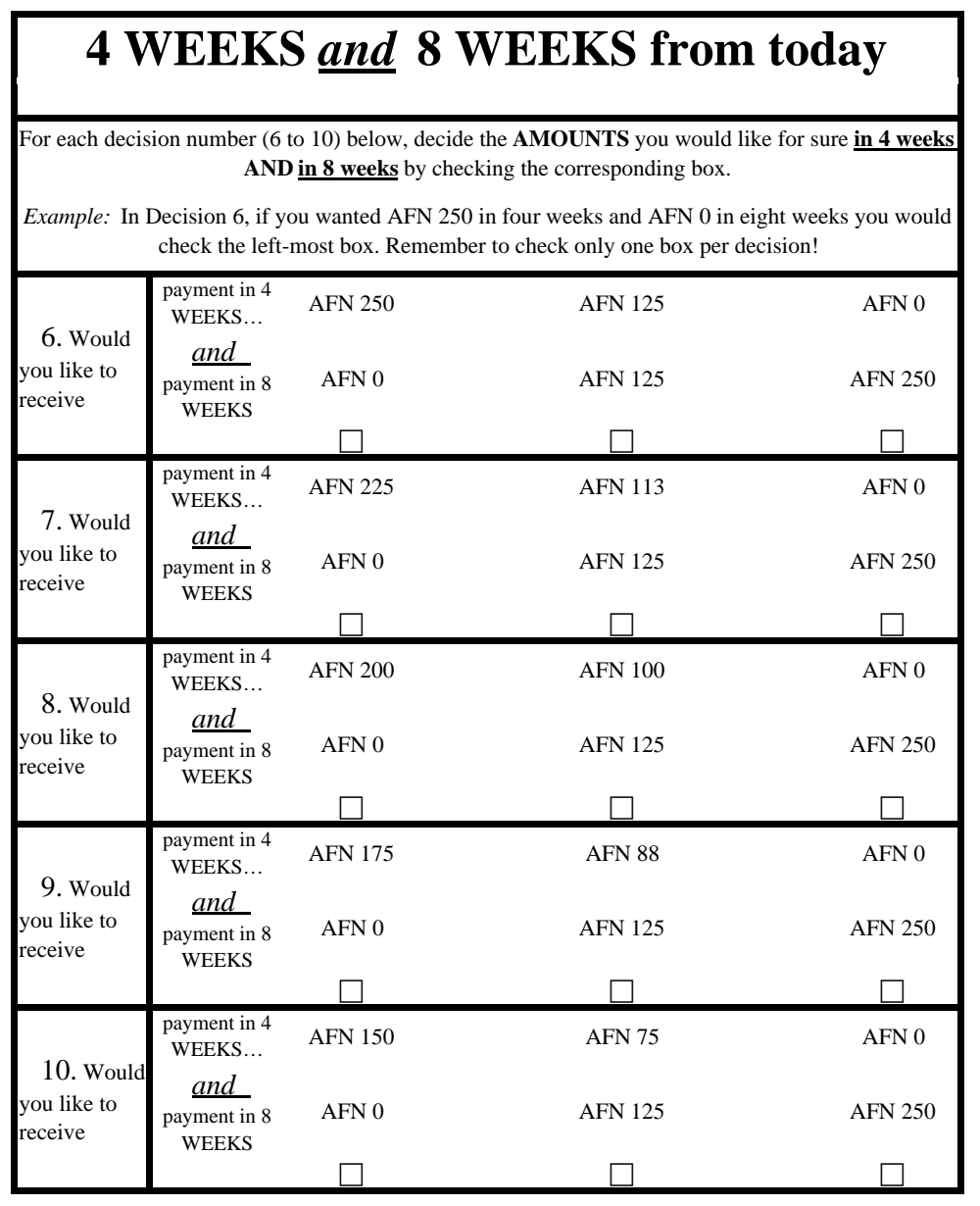

